Preventative Maintenance and Reliability Study for the Central Heating and Power Plant at Fort Wainwright, Alaska John Westerman, Robert Lorand, Charles Walden, and Curtis Swinehart 


\title{
Preventative Maintenance and Reliability Study for the Central Heating and Power Plant at Fort Wainwright, Alaska
}

\author{
John L. Vavrin, William T. Brown III, and Michael R. Kemme \\ Construction Engineering Research Laboratory \\ U.S. Army Engineer Research and Development Center (ERDC) \\ 2902 Newmark Drive \\ Champaign, IL 61822-1076 \\ John Westerman and Robert T. Lorand \\ Science Applications International Corporation \\ 8301 Greensboro Drive \\ McLean, VA 22102 \\ Charles Walden and Curtis Swinehart \\ WorleyParsons Resources and Energy \\ The WorleyParsons Group \\ 2675 Morgantown Road \\ Reading, PA 19607-9676
}

Final Report

Approved for public release; distribution is unlimited.

Prepared for U.S. Army Corps of Engineers

Washington, DC 20314-1000 


\begin{abstract}
The Technology Requirements Study for a new Central Heating and Power Plant (CHPP) at Fort Wainwright, Alaska (FWA) (Vavrin et al. 2006) recommended that if the option for a new CHPP were to be pursued, among the tasks suggested for further analysis was to determine predictive maintenance requirements and new technologies for the existing plant. This study was undertaken to develop a Preventative Maintenance (PM) assessment that includes a maintenance program overview for the major systems in the existing CHPP. The assessment entailed: (1) an identification of shortcomings and deficiencies of existing procedures and processes, (2) recommendations to overcome shortcomings and deficiencies, (3) development of a maintenance schedule, (4) development of an estimate of staffing requirements, and (5) development of a budget estimate for execution of the recommended PM program with breakout for costs, detailed annually for a period of 25 years. This study also identified, prioritized, and separately broke out new technologies and associated costs that would significantly improve the reliability of the existing CHPP.
\end{abstract}

DISCLAIMER: The contents of this report are not to be used for advertising, publication, or promotional purposes. Citation of trade names does not constitute an official endorsement or approval of the use of such commercial products. All product names and trademarks cited are the property of their respective owners. The findings of this report are not to be construed as an official Department of the Army position unless so designated by other authorized documents. 


\section{Executive Summary}

The Fort Wainwright Central Heating and Power Plant (CHPP) is critical to maintaining the operation of the military base. It provides electricity and steam to the entire installation including family housing. The CHPP was commissioned in 1954 with eight coal-fired stoker boilers and five steam turbine generators. Two boilers and one steam turbine have since been retired in place, leaving in operation six boilers of $150 \mathrm{kpph}$ each, and four steam turbine generators totaling $18 \mathrm{MW}$. The electrical power supply is supplemented by an interconnection to the local electric utility, the Golden Valley Electric Association (GVEA).

The Fort Wainwright CHPP is an aging facility that has successfully accomplished its mission of supplying steam and power primarily by sheer overcapacity. If one boiler is lost due to malfunction, another is available because of the plant's redundant capacity; six boilers were installed when normally only four to five boilers are needed during even the coldest part of winter. The ability of the electric plant to import power from the Golden Valley Electric Association (GVEA) has historically allowed the power plant to lose up to two turbines and still be able to supply the electrical needs of the community. Historically, the plant has never had a failure so catastrophic that all output from the plant stopped. If such an event occurred in the winter, installation missions and personnel would be put at risk. The plant was redundantly designed specifically to prevent such an occurrence and to provide for future growth.

However, as the installation has grown, demands on the aging CHPP have also increased. The CHPP is losing the safety reserve it has enjoyed over the past 50 years, specifically with regard to its ability to meet the installation's electric power needs. With forecasted load growth (as referenced in ERDC/CERL TR-07-36), the loss of a single steam turbine generator could create significant problems for the installation. Preventative maintenance practices should be implemented to avoid such an outage and to ensure continued plant reliability. A preventative maintenance assessment was commissioned to meet this need.

\section{Issues}

At the request of Headquarters, Installation Management Command (HQ IMCOM), an assessment team visited the CHPP the week of 27 March 
2006. The team plant's evaluated the current maintenance program and the status of equipment, training, and plant operation. The team also developed recommendations (Chapter 5) to maintain reliable plant operation. Major issues discovered during the evaluation were:

1. There is no preventative maintenance program, which means maintenance is generally reactive. This is due in part to the lack of formal maintenance budget and funding.

2. Maintenance logs have no formal tracking system. Furthermore, there are no equipment maintenance records. Access to equipment original equipment manufacturer (OEM) manuals and drawings must be improved, and staff should be trained in their use.

3. Maintenance staff should be provided with appropriate training.

\section{Recommendations}

It is recommended that FWA implement a Reliability Centered Maintenance (RCM) system to overcome these issues. An RCM system combines preventive, predictive, and overhaul maintenance with data collected from different sources, to facilitate maximum operational time at a minimum cost. Due to the limited information received regarding CHPP past operating history, recommendations in this report are to a large degree based on judgment and experience, and on manufacturer's recommendations for similar equipment.

Chapter 6 described candidate preventative maintenance diagnostic tools and their associated costs. These tools, not currently in use at the plant, are valuable tools for RCM:

- thermal imaging

- vibration analysis

- oil analysis

- ultrasonics

- eddy current

- radiography

- environmental.

A proposed budget is included to estimate the cost of implementing an RCM system to provide the high reliability that is required of the CHPP. A budget estimate for the RCM program recommended herein will range in cost from \$5-10 million per year between 2006 and 2030 (costs are in budget year dollars). Out of that estimate, $\$ 1.2$ million per year will be budgeted for Computerized Maintenance Management System (CMMS) 
hardware and labor. Table ES1 lists the cost of implementing the RCM program in year 2006 dollars. Table ES2 lists the cost of implementing the RCM program in future dollars (i.e., budget year dollars) and were escalated from the year 2006 costs. Details for this budget are presented in Section 6.3 (p 69) and Appendix D.

A formalized RCM system built around a solid core of trained personnel can improve the reliability of the CHPP, if the money and resources are properly allocated. A decrease in the forced outage rate of 50 percent is a conservative estimate made from the implementation of RCM systems at other facilities (Smith and Hinchcliffe 2004). As the plant continues to age, the cost of overhauls will increase as will the periodicity of maintenance actions. This will result in the overall costs increasing from year to year. A maintenance plan is not a magical fix for capital funding needs. As a matter of fact, it will cost more in the near term to start a maintenance program. This is because the number of failures will not instantly stop just because a preventative maintenance program has been put into place. However, the use of the technologies described in Chapter 6 will provide the ability to determine problems before failures occur. This will result in the ability to control the downtime of the machine and have maintenance occur when determined by the plant staff and not the equipment.

Table ES1. Estimated maintenance program cost summary (\$ 2006).

\begin{tabular}{|c|c|c|c|c|c|c|}
\hline \multirow[b]{2}{*}{ Maintenance Cost Category } & \multicolumn{6}{|c|}{ Estimated Maintenance Program Cost, (2006 dollars) } \\
\hline & $2006-2010$ & 2011-2015 & $2016-2020$ & 2021-2025 & $2026-2030$ & Total \\
\hline Boilers 1 through 6 & $7,500,000$ & $6,980,000$ & $8,010,000$ & $8,690,000$ & $10,070,000$ & $41,250,000$ \\
\hline Steam Turbines 1, 3, 4 and 5 & $5,750,000$ & $2,900,000$ & $3,360,000$ & $3,900,000$ & $4,520,000$ & $20,430,000$ \\
\hline Balance of Plant & $5,330,000$ & $3,260,000$ & $3,750,000$ & $3,290,000$ & $4,180,000$ & $19,810,000$ \\
\hline New Technology & 320,000 & 190,000 & 240,000 & 190,000 & 240,000 & $1,160,000$ \\
\hline Owner's Costs (Engineering @ 5\%) & 940,000 & 670,000 & 770,000 & 800,000 & 950,000 & $4,130,000$ \\
\hline Project Contingency & $4,960,000$ & $4,200,000$ & $5,650,000$ & $6,740,000$ & $7,980,000$ & $29,530,000$ \\
\hline Total Plant Maintenance Cost (excluding Staffing) & $24,800,000$ & $18,200,000$ & $21,780,000$ & $23,600,000$ & $27,940,000$ & $116,320,000$ \\
\hline Total Plant Labor Cost (Recommended Staffing) & $5,490,000$ & $5,490,000$ & $5,490,000$ & $5,490,000$ & $5,490,000$ & $27,470,000$ \\
\hline Total Plant Cost & $30,290,000$ & $23,700,000$ & $27,270,000$ & $29,100,000$ & $33,430,000$ & $143,790,000$ \\
\hline Average Cost per Year (\$/year) & $6,058,000$ & $4,740,000$ & $5,454,000$ & $5,820,000$ & $6,686,000$ & $5,751,600$ \\
\hline
\end{tabular}


Table ES2. Estimated maintenance program cost summary (future costs).

\begin{tabular}{|c|c|c|c|c|c|c|}
\hline \multirow[b]{2}{*}{ Maintenance Cost Category } & \multicolumn{6}{|c|}{ Estimated Maintenance Program Cost, (Future Cost) } \\
\hline & 2006-2010 & 2011-2015 & 2016-2020 & $2021-2025$ & $2026-2030$ & Total \\
\hline Boilers 1 through 6 & $7,840,000$ & $8,100,000$ & $10,330,000$ & $12,430,000$ & $16,010,000$ & $54,720,000$ \\
\hline Steam Turbines 1, 3, 4 and 5 & $6,050,000$ & $3,370,000$ & $4,350,000$ & $5,620,000$ & $7,250,000$ & $26,650,000$ \\
\hline Balance of Plant & $5,570,000$ & $3,810,000$ & $4,890,000$ & $4,780,000$ & $6,780,000$ & $25,830,000$ \\
\hline New Technology & 320,000 & 220,000 & 300,000 & 270,000 & 370,000 & $1,480,000$ \\
\hline Owner's Costs (Engineering @ 5\%) & 990,000 & 780,000 & 990,000 & $1,160,000$ & $1,520,000$ & $5,430,000$ \\
\hline Project Contingency & $5,200,000$ & $4,880,000$ & $7,300,000$ & $9,700,000$ & $12,770,000$ & $39,850,000$ \\
\hline Total Plant Maintenance Cost (excluding Staffing) & $25,980,000$ & $21,170,000$ & $28,160,000$ & $33,960,000$ & $44,700,000$ & $153,960,000$ \\
\hline Total Plant Labor Cost (Recommended Staffing) & $5,770,000$ & $6,500,000$ & $7,330,000$ & $8,270,000$ & $9,320,000$ & $37,200,000$ \\
\hline Total Plant Cost & $\overline{31,740,000}$ & $\overline{27,670,000}$ & $\overline{35,500,000}$ & $\overline{42,230,000}$ & $\overline{54,020,000}$ & $191,160,000$ \\
\hline Average Cost per Year (\$lyear) & $6,348,000$ & $5,534,000$ & $7,100,000$ & $8,446,000$ & $10,804,000$ & $7,646,400$ \\
\hline
\end{tabular}




\section{Contents}

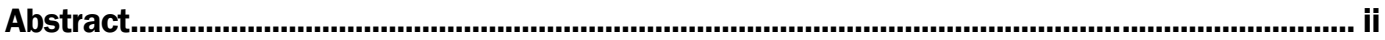

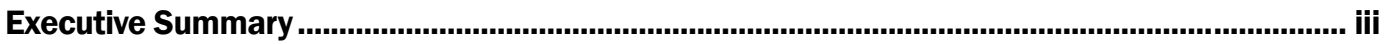

Figures and Tables........................................................................................................................................

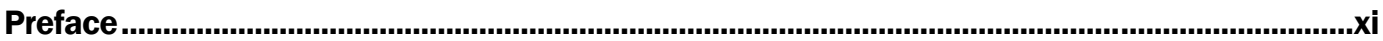

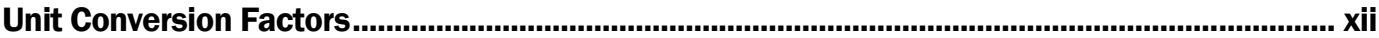

Terminology Used in this Report ............................................................................................ii

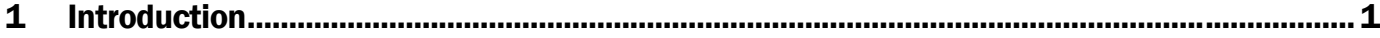

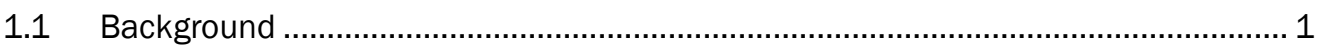

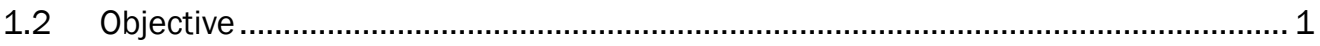

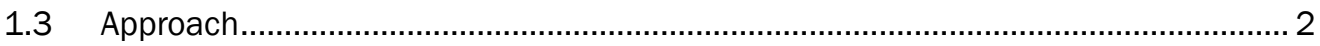

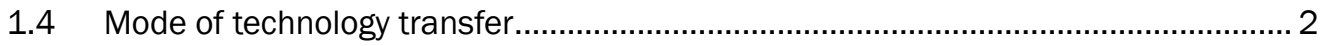

2 Brief Plant Description .............................................................................................................

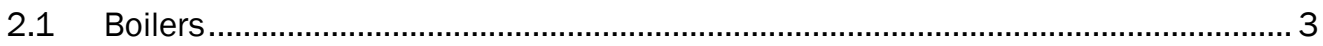

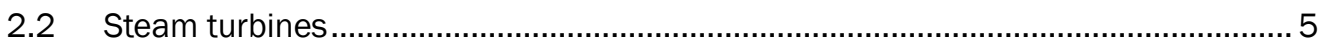

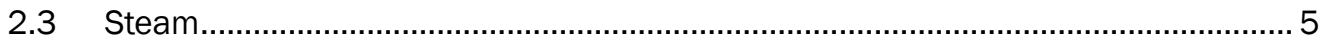

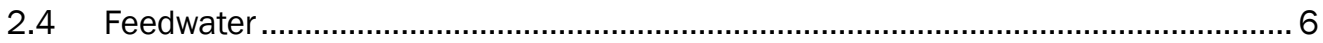

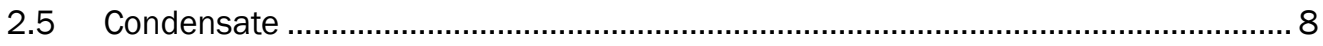

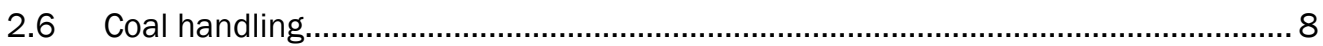

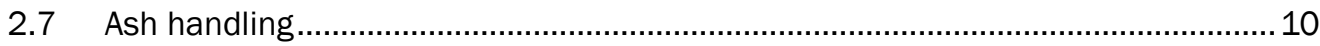

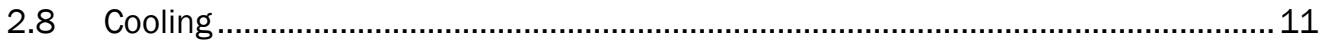

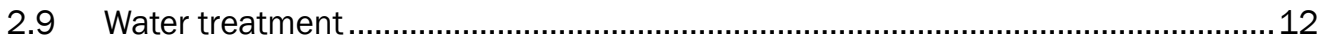

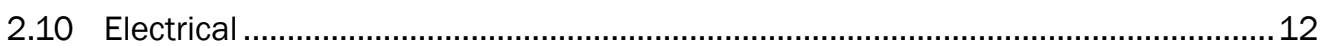

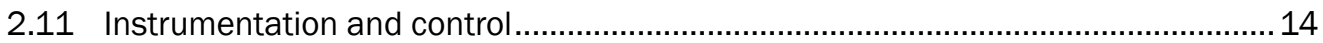

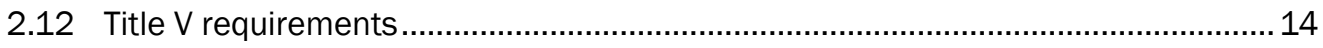

$\begin{array}{ll}\text { 2.12.1 Baghouse requirements } & 15\end{array}$

2.12.2 Continuous opacity monitoring system requirements $\quad 15$

$\begin{array}{ll}2.12 .3 \text { Continuous emissions monitoring system } & 17\end{array}$

2.12.4 Steam flow orifice plate requirements $\quad 17$

$\begin{array}{ll}2.12 .5 \text { Coal scale requirements } & 19\end{array}$

3 Overview of Existing Maintenance Management Program …...........................................20

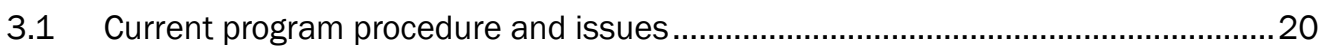

$\begin{array}{lll}3.1 .1 & \text { Description of procedure } & 20\end{array}$

$\begin{array}{ll}3.1 .2 & \text { Description of issues }\end{array}$

3.1.3 Limited long range maintenance planning 28

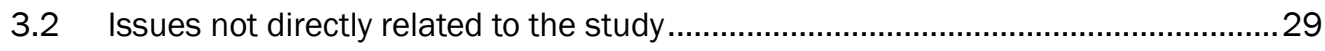

4.2.1 Safety program $\quad 29$

4.2.2 Plant operations- training and procedures 30

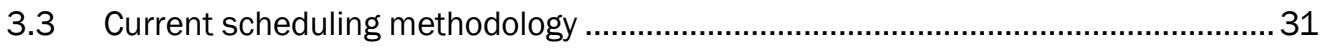


3.4 Major maintenance and overhaul assessment............................................... 31

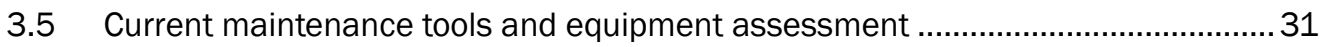

3.6 Preventative maintenance schedule review .................................................. 31

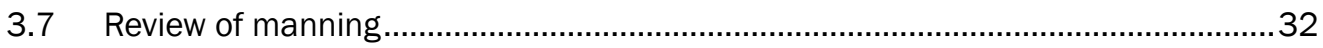

3.7.1 Current staffing $\quad 32$

3.7.2 Contracted services 33

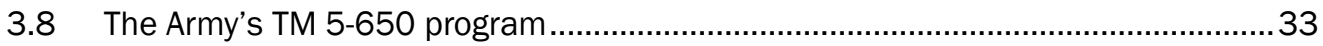

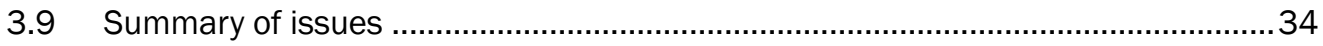

$\begin{array}{lll}3.9 .1 & \text { Summary of issues } & 34\end{array}$

3.9.2 Summary of issues not related to study $\quad 35$

4 New Technologies ...............................................................................................................36

4.1 Computerized maintenance management system (CMMS) ...................................36

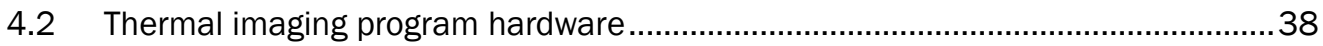

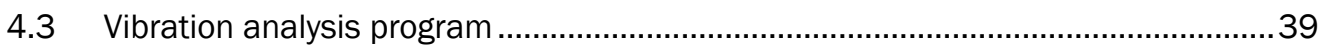

4.4 Oil analysis program....................................................................................... 40

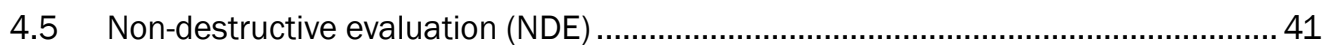

$\begin{array}{lll}4.5 .1 & \text { Ultrasonic inspection } & 42\end{array}$

4.5.2 Eddy current testing $\quad 42$

$\begin{array}{lll}4.5 .3 & \text { Radiography } & 43\end{array}$

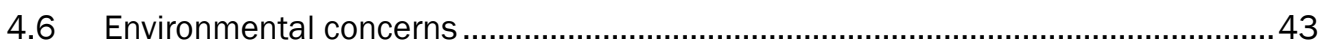

4.6.1 Baghouse leak detection and performance measurement improvements 43

4.6.2 Baghouse leak detectors based on triboelectric effect 45

4.7 Prioritization of new technologies ....................................................................46

6.7 Estimated maintenance program costs with recommended technologies.............. 47

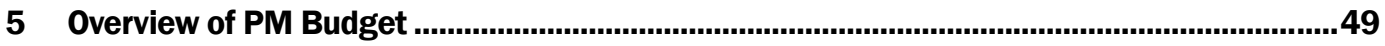

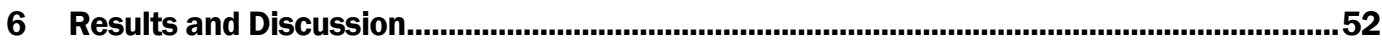

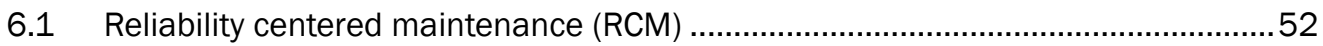

6.2 Estimated implementation schedule ......................................................................5 55

6.2.1 General implementation $\quad 55$

6.2.2 Schedule by system $\quad 58$

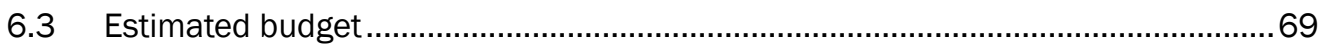

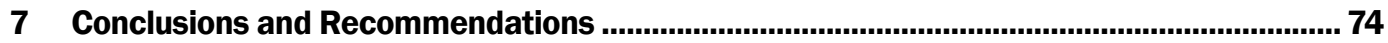

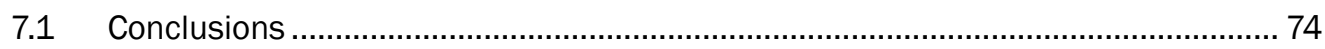

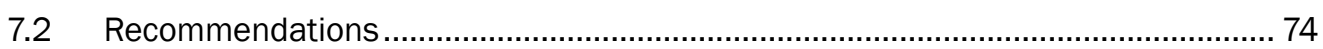

References............................................................................................................................... 76

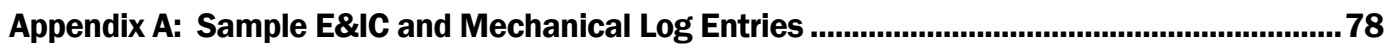

Appendix B: Sample CHPP Monthly Inspection and Lubrication Checklist .............................80

Appendix C: TM 5-650, Chapter 5, “Inspection and Preventative Maintenance”......................84

Appendix D: Fort Wainwright Cost Details................................................................................. 101

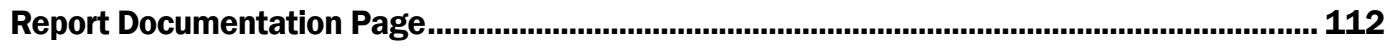




\section{Figures and Tables}

\section{Figures}

1 Simplified diagram of boilers, steam and steam turbine systems (Source:

Raytheon Engineers and Constructors August 1996)................................................. 4

2 Feedwater and condensate simplified diagram (Source: Raytheon Engineers and Constructors August 1996)................................................................................... 7

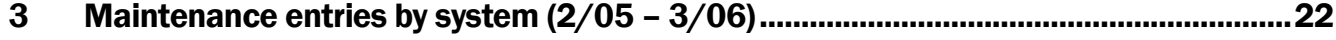

4 Boiler systems maintenance entries $(2 / 05$ - 3/06) ...................................................22

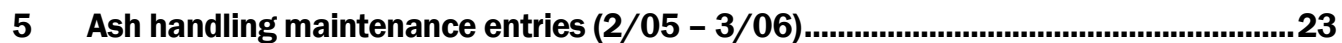

6 Miscellaneous maintenance entries (2/05 - 3/06) ....................................................23

$7 \quad$ Feedwater and condensate maintenance entries $(2 / 05-3 / 06)$....................................24

8 Steam turbines maintenance entries $(2 / 05$ - 3/06) ...................................................24

9 Coal handling maintenance entries (2/05 - 3/06) .........................................................25

10 Electrical and controls maintenance entries $(2 / 05$ - 3/06) ........................................25

11 Make-up Water Maintenance Entries (2/05 - 3/06) …….........................................26

12 Monitoring system schematic (Source: GEA Power Cooling Systems

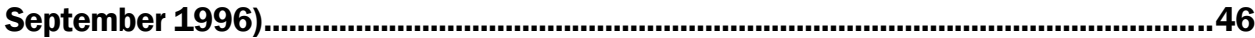

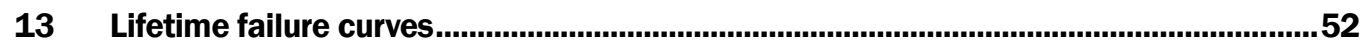

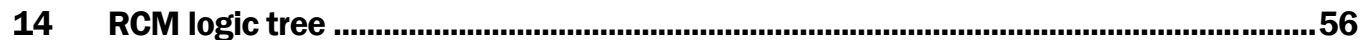

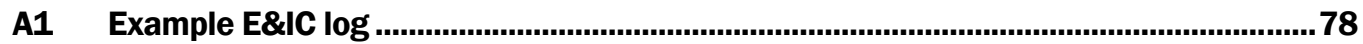

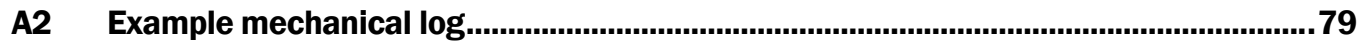

B1 CHPP monthly inspection and lubrication checklist ....................................................80

\section{Tables}

ES1 Estimated maintenance program cost summary (\$ 2006) ............................................

ES2 Estimated maintenance program cost summary (future costs) .....................................vi

1 ACC project schedule. (Source: Personal communication with Darrell Jaeke,

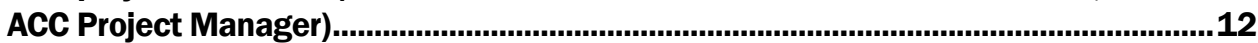

2 Maintenance entries breakdown by subsystem (2/05 - 3/06) …….............................26

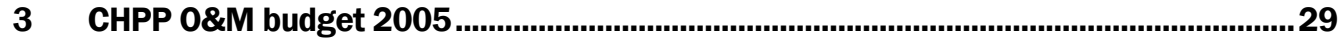

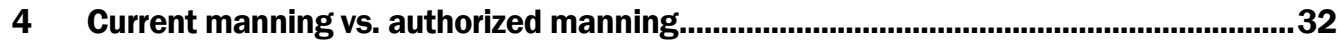

5 Recommended manning additions..............................................................................33

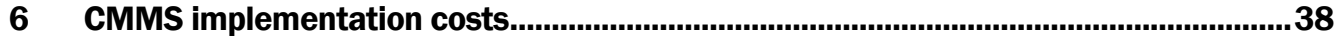

7 In-house thermal imaging implementation costs...........................................................39

8 Cost for vibration program implementation ...............................................................40 


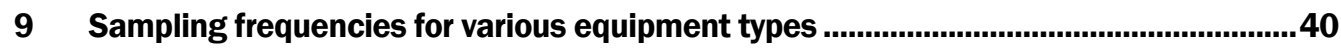

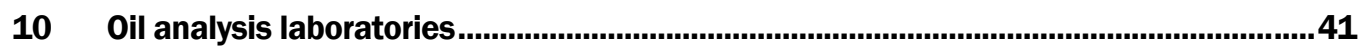

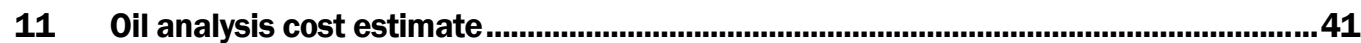

12 In-house ultrasonic inspection implementation costs ..............................................42

13 Estimated maintenance program cost for new technologies (\$2006) .........................48

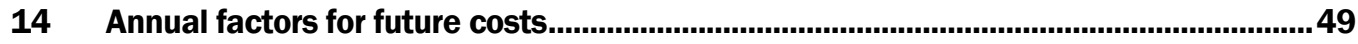

15 Preventative maintenance budget - future costs .........................................................50

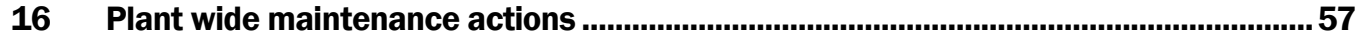

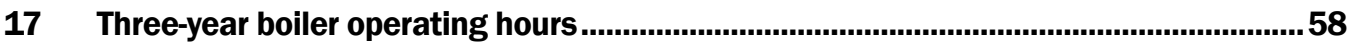

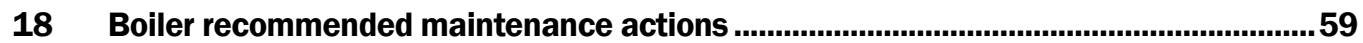

19 Recommended steam turbine maintenance............................................................60

20 Recommended feedwater system maintenance ......................................................61

21 Recommended condensate system maintenance .............................................................62

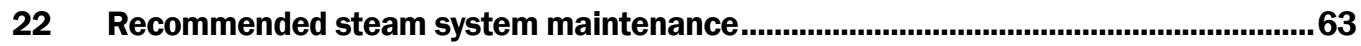

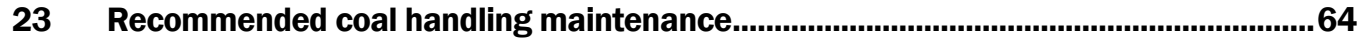

24 Recommended ash handling maintenance..............................................................64

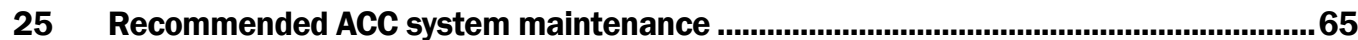

26 Recommended water treatment maintenance schedule .........................................66

27 Transformer inspection/maintenance program ...........................................................66

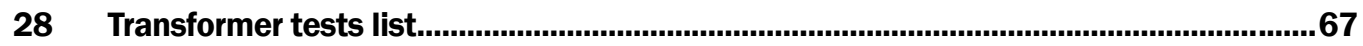

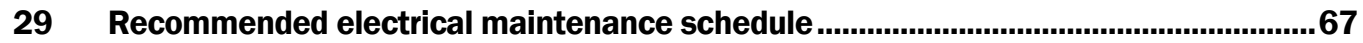

30 Estimated maintenance program cost summary $(\$ 2006)$ 


\section{Preface}

This study was conducted for Headquarters, Installation Management Command (HQ IMCOM) under Military Interdepartmental Purchase Request (MIPR) 6CCERB1011R, "Annex 46 Holistic Assessment Toolkit on Energy Efficient Retrofit Measures for Government Buildings (EnERGo)"; Project Requisition No. 127396. The technical monitor was Paul Volkman, HQ-IMCOM.

The work was performed by the Energy Branch (CF-E) of the Facilities Division (CF), Construction Engineering Research Laboratory (CERL). The CERL Project Managers were John L. Vavrin and William T. Brown III, who led the U.S. Army Engineer Research and Development Center (ERDC) Project Delivery Team (PDT), assisted by Dr. Thomas J. Hartranft and Michael R. Kemme. The work was done by Science Applications International Corporation and Worley Parsons under Delivery Order No. 0002, Contract No. W9132T-04-D-0001. Special acknowledgement is given to the Fort Wainwright, Alaska Directorate of Public Works (FWA DPW), Headquarters, U.S. Army Corps of Engineers (HQUSACE), Corps of Engineers Pacific Ocean Division (CEPOD), Corps of Engineers Alaska District (CEPOA), Pacific Region Office, Installation Management Command (PARO-IMCOM), U.S. Army Alaska (USARAK), and the Directorate of Engineering, U.S. Army Engineering and Support Center, Huntsville (CEHNC) for providing assistance required to conduct this study. Dr. Thomas J. Hartranft is Chief, CEERD-CF-E, and Michael Golish is Chief, CEERD-CF. The associated Technical Director is Martin J. Savoie, CEERD-CV-T. The Director of CERL is Dr. Ilker R. Adiguzel.

CERL is an element of the U.S. Army Engineer Research and Development Center (ERDC), U.S. Army Corps of Engineers. The Commander and Executive Director of ERDC is COL Richard B. Jenkins, and the Director of ERDC is Dr. James R. Houston. 


\section{Unit Conversion Factors}

\begin{tabular}{|c|c|c|}
\hline Multiply & By & To Obtain \\
\hline acres & $4,046.873$ & square meters \\
\hline British thermal units (International Table) & $1,055.056$ & joules \\
\hline cubic feet & 0.02831685 & cubic meters \\
\hline cubic inches & $1.6387064 \mathrm{E}-05$ & cubic meters \\
\hline cubic yards & 0.7645549 & cubic meters \\
\hline degrees Fahrenheit & $(F-32) / 1.8$ & degrees Celsius \\
\hline fathoms & 1.8288 & meters \\
\hline feet & 0.3048 & meters \\
\hline gallons (U.S. liquid) & 3.785412 E-03 & cubic meters \\
\hline hectares & $1.0 \mathrm{E}+04$ & square meters \\
\hline inches & 0.0254 & meters \\
\hline miles (U.S. statute) & $1,609.347$ & meters \\
\hline pounds (mass) & 0.45359237 & kilograms \\
\hline square feet & 0.09290304 & square meters \\
\hline square inches & $6.4516 \mathrm{E}-04$ & square meters \\
\hline square miles & $2.589998 \mathrm{E}+06$ & square meters \\
\hline square yards & 0.8361274 & square meters \\
\hline tons ( 2,000 pounds, mass) & 907.1847 & kilograms \\
\hline yards & 0.9144 & meters \\
\hline
\end{tabular}




\section{Terminology Used in this Report}

$\underline{A}$

ACC air cooled condenser

ASHRAE American Society of Heating Refrigeration and Air Conditioning Engineers.

$\underline{B}$

B\#3 Boiler no. 3, (for example)

Btu British thermal unit

$\underline{\mathrm{C}}$

cfm cubic feet per minute

CHPP Central Heating and Power Plant

CMMS Computerized Maintenance Management System

CM Condition based Maintenance

$\underline{D}$

DA deaerator

DCS Distributed Control System

E

El electric

EI\&C Electrical, Instrumentation and Control

F

${ }^{\circ} \mathrm{F} \quad$ degrees Fahrenheit

FD forced draft fan

Ft feet

FW feedwater

$\underline{G}$

gpm gallons per minute

GVEA Golden Valley Electric Association

$\underline{\mathrm{H}}$

h, hr hour

$\mathrm{Hp}$ horsepower

$\mathrm{Hz} \quad$ Hertz, (frequency, cycles per sec.)

I

I\&C instrumentation and controls

in $\mathrm{Hg}$, a inches mercury, absolute

$\underline{\mathrm{K}}$

kV kilovolt

kVA kilovolt-amperes

kW kilowatt
$\underline{M}$

Max. maximum

Min. minimum

MW megawatt

MWe megawatt electric

MWh megawatt-hour

MWt megawatt thermal

$\underline{N}$

NA not applicable, not available

NDE non-destructive examination

$\underline{0}$

O\&M operation and maintenance

OEM original equipment manufacturer

$\underline{P}$

P\&ID Piping and Instrumentation Diagram

PM Preventative Maintenance

PPE Personal Protective Equipment

psi lb/square inch

PRV pressure reducing valve

$\underline{\mathrm{R}}$

RCM Reliability Centered Maintenance

RO Reverse Osmosis

$\underline{\mathbf{S}}$

ST steam turbine

STG steam turbine generator

I

TG turbo-generator, (turbine-generator)

$\underline{U}$

UCC United Conveyor Company

USD United States Dollars

$\underline{V}$

$\mathrm{V} \quad$ volts

VF variable frequency

$\underline{Y}$

y, yr year 


\section{Introduction}

\subsection{Background}

The Fort Wainwright CHPP consists of six coal-fired boilers and four steam turbine generators that supply steam and electricity to the Post. The electrical power supply is supplemented by an interconnection to the Golden Valley Electric Association (GVEA), the local electric utility. The Fort Wainwright CHPP is an aging facility that has been successful in its mission of supplying steam and power primarily by its sheer overcapacity. If one boiler is lost due to malfunction or operator error, another boiler is available because of the redundancy of having six boilers installed when normally only four to five boilers are needed for the coldest part of winter. The ability of the electric plant to import power from the Golden Valley Electric Association (GVEA) has historically allowed the power plant to lose up to two turbines and still be able to supply the critical electrical needs of the community.

However, as the installation has grown, demands on the aging CHPP have also increased. The CHPP is losing the safety reserve it has enjoyed over the past 50 years, specifically in its ability to meet the installation's electric power needs. With forecasted load growth, the loss of a single steam turbine generator could create significant problems for the installation. Preventative maintenance practices should be implemented to avoid such an outage and to ensure continued plant reliability. A preventative maintenance assessment was commissioned to meet this need.

\subsection{Objective}

The objective of this work was to:

1. Assess the state of the maintenance management system at the CHPP

2. Identify areas in the current process requiring improvement

3. Recommend changes to implement these improvements

4. Produce proposed maintenance schedules for the major systems

5. Estimate staffing requirements, materials, and equipment required for the maintenance program

6. Estimate a budget required to execute the recommended program over a period of 25 years. 


\subsection{Approach}

CERL led an assessment team with contracted assistance from Science Applications International Corp. (SAIC) and WorleyParsons, Inc, which visited the CHPP during the week of 27 March 2006. The current maintenance program was evaluated as was the status of equipment, training, and plant operation. The team developed recommendations (documented in this report) to ensure that reliable plant operation is maintained.

The remainder of this report is organized into the following Chapters:

- Chapter 2 Brief Plant Description

- Chapter 3. Overview of Existing Maintenance Management Program

- Chapter 4. New Technologies

- Chapter 5. Overview of PM Budget

- Chapter 6. Results and Discussion

- Chapter 7. Conclusions and Recommendations.

\subsection{Mode of technology transfer}

This report will be made accessible through the World Wide Web (WWW) at URL: http://www.cecer.army.mil 


\section{Brief Plant Description}

This chapter briefly describes the major CHPP plant systems:

- Boilers

- Steam Turbine Generators

- Steam System

- Feedwater System

- Condensate System

- Coal Handling system

- Ash Handling System

- Cooling System

- Water Treatment System

- Electrical System

- Instrument and Controls System

- Environmental (Title V) Requirements.

A more detailed review of the plant design and operating characteristics can be found Technology Requirements Study for a New Central Heating and Power Plant at Fort Wainwright, AK (Vavrin, et al. September 2006), prepared by this team as part of a previous task.

\subsection{Boilers}

Figure 1 shows a simplified diagram of the boilers, steam, and steam turbine systems. The CHPP is equipped with eight boilers. Boilers 1 and 2 have been abandoned in place since a major plant reconstruction in 1954. Boilers 3 through 8 were commissioned in 1954 and are still in operation. The boilers are identical, manufactured by Wickes Boiler Co. and erected by Wyatt and Kipper Engineers. Boilers 3 through 8 are arranged in two rows, with odd numbered units on the east side and even numbered units on the west side of the building.

The boilers are R-model, two-drum, bottom supported, natural circulation, balanced draft technology, each equipped with six continuous discharge under-throw type spreader stokers and one forward traveling grate. The boiler furnace is a bent-tube type, refractory-lined and steel cased. 


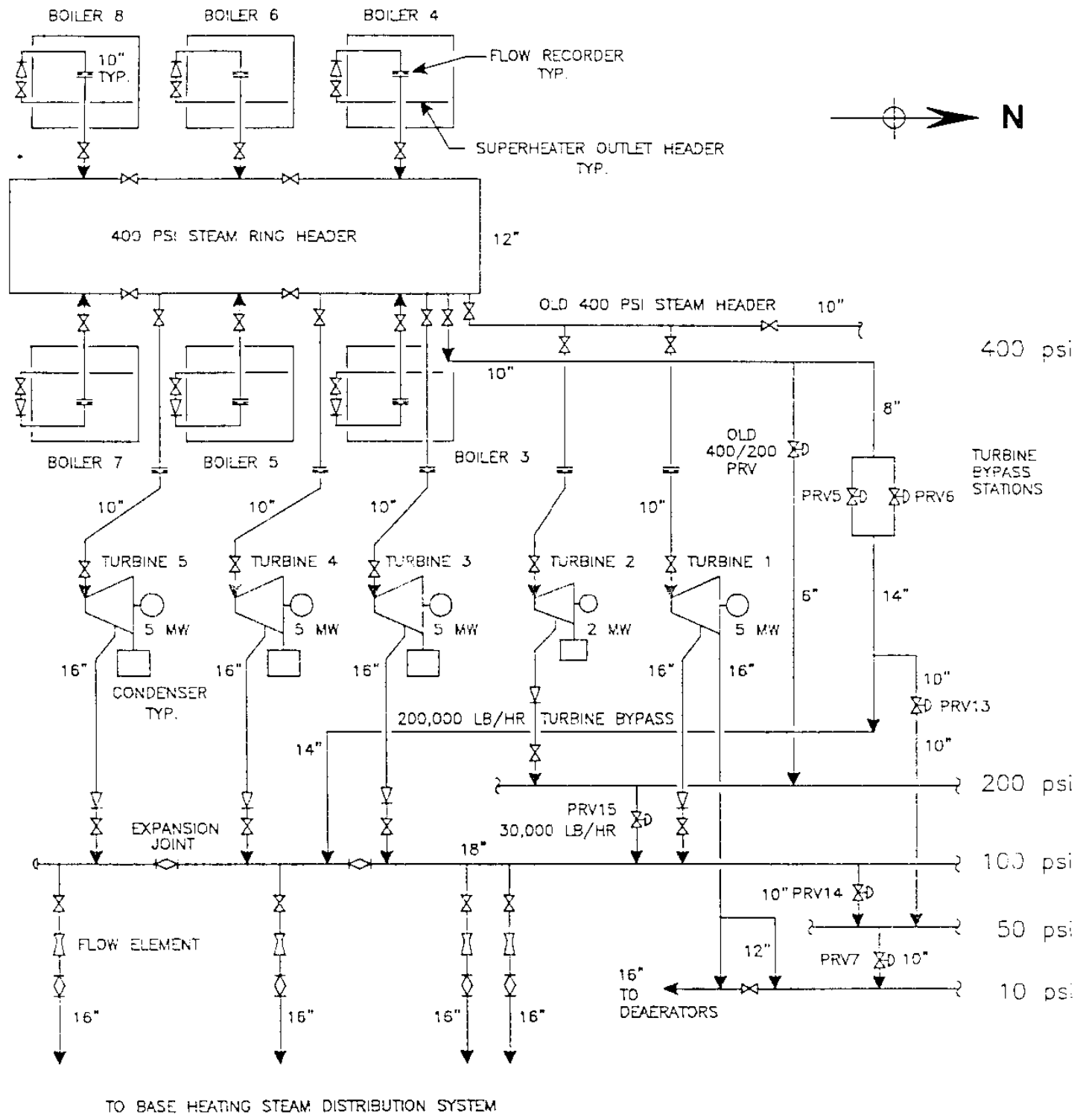

Figure 1. Simplified diagram of boilers, steam and steam turbine systems (Source: Raytheon Engineers and Constructors August 1996).

The boilers are equipped with pendant type convection superheaters and drainable bare-tube economizers. Overpressure protection for each boiler is accomplished by five safety relief valves (SRV), set in 5 psig increments from 455 psig to 475 psig. The boilers have a continuous rating of 150 kpph steam flow with a design pressure and temperature of $425 \mathrm{psig} / 670$ ${ }^{\circ} \mathrm{F}$ (DEFC March 2005). 


\subsection{Steam turbines}

The plant is equipped with five steam turbine-generators (STG), all manufactured by GE. Turbines 3 through 5 are single casing controlled extraction machines, each with a rated output of $5 \mathrm{MWe}$ on $12.47 \mathrm{kV}$ generator terminals, discharging to a water-cooled surface condenser with a design exhaust pressure of 1.5-in. Hg, The condenser OEM is Graham Manufacturing of New York. STG-1 is a 5 MW back-pressure machine, supplying 10 psig exhaust steam for plant needs. Due to the reduced plant demand for 10 psig steam, the STG- 1 output is currently limited to a nominal 3 MWe during the summer and approximately 4 MWe during the winter. STG-2 is a 2 MWe condensing machine that has been abandoned in place. The 100 psig steam extracted from turbines 1 and 3 through 5 is sent to the Fort Wainwright heating system via four feed lines.

Cooling water for the condenser has been supplied from the cooling pond. A project currently under way will replace the water-cooled condensers with air-cooled condensers (ACC). This project is expected to be completed in September 2007 (personal communication with Darrell Jaeke). The ACC design is based on 5 in $\mathrm{Hg}$, turbine exhaust pressure at dry bulb (DB) ambient temperature of $82{ }^{\circ} \mathrm{F}$ (1 percent ASHRAE design temperature) (U.S. Army Corps of Engineers, Alaska District 20 September 2004). It is assumed that the turbine operation with an ACC will not result in an increase of the turbine performance deterioration rate and will not require an increased maintenance frequency.

\subsection{Steam}

The six boilers are connected to a 12-in. steam loop header with sectionalizing valves. This steam header operates at 400 psig and $650^{\circ} \mathrm{F}$. From the 400 psig steam header, a 10-in. branch supplies STG-1 and the new boiler feed water pump's steam turbine drive. Three additional 10-in. branches from the steam header supply the other three steam turbines. A fifth 10-in. branch supplies the existing boiler feed water pump's steam turbine drive (to be abandoned), two 400/100 psig pressure reducing valve (PRV) stations (200,000 lb/h total capacity), and a 400/200 psig PRV station.

A $30,000 \mathrm{lb} / \mathrm{hr} 200 / 100$ psig PRV station is supplied by the 200 psig line. All of the 100 psig lines from the turbine extraction and the PRV station are connected to an 18-in. steam header. The 100 psig header supplies four 
16-in. lines connected to the FWA heat distribution system. There is one desuperheater station on each of the 16-in. lines to the FWA heating system. There are two 100/50 psig PRV stations from the 100 psig heater that can supply steam to the plant heating system that includes the combustion air heating system. The combustion air is heated with a glycol system when the outside air temperature is below $20^{\circ} \mathrm{F}$. There is a $50 / 10$ psig PRV station in series with one of the 100/50 psig PRV stations that supplies 10 psig steam to the deaerators (DEFC March 2005).

Sections of 400 psig, 100 psig, and $10 \mathrm{psig}$ piping have been repaired/ replaced in recent years (U.S. Army Corps of Engineers Alaska District 11 March 2005). Existing 400 psig system valves were replaced with new rotary metal seated valves (U.S. Army Corps of Engineers drawing, M6-1, sheet 87 ), existing 18 -in. 100 psig system bellow joints were replaced, and new trap stations and new sectionalizing valves were installed on the 100 psig steam header to allow for repairs on the section of the header (U.S. Army Corps of Engineers drawing M7-1, sheet 90).

\subsection{Feedwater}

Figure 2 shows a simplified diagram of the feedwater and condensate systems.

The feedwater system (FW) is equipped with two deaerators (DA) supplied with 10 psig steam. The older DA was installed in 1940s, and a new DA was added in 1953. Each DA is sized to satisfy the full plant capacity. However, both DAs are interconnected and always in operation. Vent condensers were replaced on both DAs several years ago.

The FW system is equipped with three FW pumps. Two FW pumps are electric motor driven. One FW pump is dual electric motor and steam turbine driven on a common pump shaft with clutch and couplings. The pumps are approximately 4 years old. The plant is experiencing problems with these new FW pumps (vibration, clutch/brake, and bearing-oil lubrication problems). Major repairs have been performed on the new FW pumps by the manufacturer due to problems in design and workmanship (Personal communciation with Vic Lemay). The FW pumps supply water to a 10-in. feed water header that serves all boilers. 


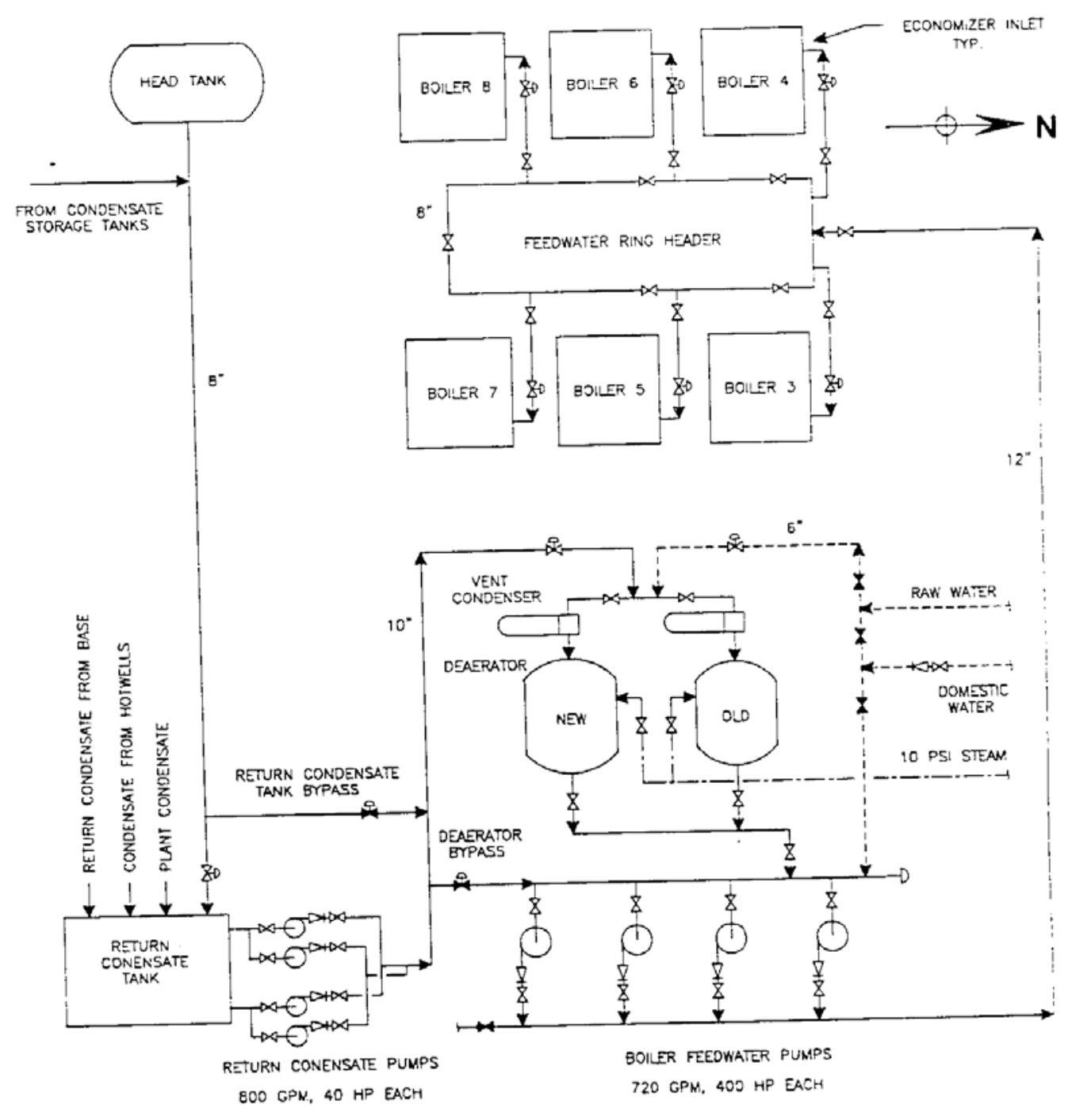

Figure 2. Feedwater and condensate simplified diagram (Source: Raytheon Engineers and Constructors August 1996).

The FW header was partially replaced in 2001. At that time, an oxygen scavenger was added to the new DA. A dispersant and neutralizing amine were added to the suction header of the FW pumps. The system's current peak duty is $460,000 \mathrm{lb} / \mathrm{h}$ (918 gpm) (Telephone conversation with Vic Lemay and Dave Brenner 12 April 2005). The system design peak duty is 778,00o lb/h (1,553 gpm) (H.W. Beecher Architects-Engineers 22 July 1952). The original pumps are in place and are being maintained as a backup (turned on for several minutes once a week). 


\subsection{Condensate}

The CHPP condensate return rate is 75 percent of the district heating loop steam load. There are three condensate return mains from the installation system where the condensate flows into three sumps. Condensate from the sumps is transferred to a new 15,300-gal capacity condensate tank. Condensate from the tank is transferred by three condensate polisher booster pumps to a $925 \mathrm{gpm}$ sodium cycle cation condensate polisher assembly. Each of the booster pumps has a capacity of $463 \mathrm{gpm}$ at $100 \mathrm{ft}$ of head with a 20 horsepower electric motor.

The polisher assembly has three polisher tanks, each with a 463 gpm treatment capacity. The polishers are regenerated with brine from a tank. The polished condensate flows to an 8,60o-gal condensate receiver tank. Condensate from the receiver tank is pumped to the two deaerators by four condensate transfer pumps, each with an 800 gpm capacity at $150 \mathrm{ft}$ head. Three of the pumps are electric driven, while the fourth is a steam turbine driven pump (DEFC March 2005).

All condensate tanks and pumps have been replaced and a condensate polisher has been added within the last couple of years. All condensate piping (up to the deaerator) including water treatment piping was replaced in 1997 (Raytheon Engineers and Constructors August 1996).

\subsection{Coal handling}

There are two coal handling systems at the CHPP, a south system and a north system. The north system has only a truck unloading system and is a backup system used only during a south system failure. The south coal handling system is the primary coal unloading facility. The CHPP receives its coal via rail from Usibelli Coal Mine, Inc., located in Healy, AK. Coal trains may consist of 80-ton and 100-ton cars. During the winter, the coal cars are directed to the thawing shed installed in 2002 and sized for nine cars. The south coal receiving system is equipped with two track grizzlies. Coal is dumped from the cars into either grizzly and proceeds into the track hopper that feeds apron feeders. Coal from the apron feeder is transferred to a belt conveyer, which feeds a coal crusher.

The belt conveyer is equipped with a magnetic head pulley to remove tramp ferrous material from coal. Coal size as received is 4-in. $\mathrm{x} 0$-in. The 
coal crusher design rate is 175 tons/hr. It reduces coal to the size of 2-in. $\mathrm{x}$ o-in. The coal crusher is equipped with a bypass system. The crushed coal is lifted by a bucket elevator approximately $120 \mathrm{ft}$, and feeds a two-way belt conveyer. The two-way conveyer can supply an over bunker flight conveyor network to feed the boiler bunkers, or can be reversed to discharge crushed coal to the coal yard. The over the bunker conveyer network is fully enclosed. Coal from the two-way conveyer is fed onto the west side feed conveyer that moves coal from south to north over the day bunkers of Boiler nos. 4, 6, and 8. The remaining coal is discharged to a cross conveyer that moves coal from west to east and feeds the east side conveyer. The east side feed conveyer moves coal from north to south over the day bunkers of Boiler nos. 3, 5, and 7. Any leftover coal after Boiler no. 7 on the east flight conveyer is discharged to another cross conveyer that moves coal to the west side completing the loop. Coal day bunkers are sized for 500 tons, for a total of 3,000 tons. Each day bunker is equipped with three gates. The coal feeding system is equipped with new $200 \mathrm{lb}$ feed control scales.

The coal pile is located outdoors and typically contains a 90-day inventory. Coal can be reclaimed from the coal pile using a dedicated hopper, apron feeder and conveyer belt to the coal crusher.

The coal handling system operates one 10-hr shift per day with a typical system load of 14 cars/day. The peak load is 1100 tons/day. The design capacity is 150 tons/hr, and the actual average capacity is $110-120$ tons $/ \mathrm{hr}$.

Most of the major coal handling system components were reported as being refurbished, replaced or modified between 2001 and 2005 (Alaska District August 1998). This includes track grizzlies, truck grizzlies, apron feeders, coal crusher, coal elevator, all lower-level conveyers, electric motors, over the bunker conveyer network, new coal bunker air cannons, chutes, grates, and non-segregating distributors. The north coal yard (backup) repair/upgrade was recently completed. The north coal system upgrade included the replacement of truck hopper, pan conveyor, belt conveyor, dust enclosures, magnetic separator, crusher and bypass, collection chutes, bucket elevator, and cross-over conveyor. 
A new coal dust collection system consisting of two bag filtration systems, one with a $13,150 \mathrm{cfm}$ fan and the second one with a 9,250 $\mathrm{cfm}$ fan, was placed into operation in 2004.

\subsection{Ash handling}

The CHPP ash collection system is a continuous vacuum type. The ash handling system includes heavier ash from the bottom ash hoppers, riddling ash hoppers and the multi-clone hoppers of the boilers, as well as fly ash. There is a reinforced concrete silo structure with an internal vertical steel wall that forms two separate silos, one for bottom ash and the other for fly ash, finer ash from the riddling hopper, and the existing multi-cone fly ash hopper from each boiler. The ash silos have funnel bottoms with pneumatic thumpers and steam heaters. The finer ash silo has a dry fly ash unloading mechanism; the other silo has a wet unloading system. The ash from the silos is unloaded to trucks that transport the ash to the landfill at the northern end of FWA.

Bottom ash disposal includes one clinker grinder in each of the four doghouses of the bottom ash hopper for each boiler. The bottom ash is conveyed by vacuum in an 8-in. pipe to primary/secondary centrifugal separators. The primary/secondary centrifugal separators are located at the top of the ash silo. At the separators, heavier ash is separated from the motive air and drops into the ash silo. The finer ash rides with the motive air and proceeds to a baghouse separator, the separated ash goes to the 168 ton ash silo, and the motive air is moved by a root blower and is exhausted though mufflers. The separators, baghouse, and root blower are all located on the top of the silo.

Ash from riddling hoppers from three boilers is conveyed by a 6-in. vacuum pipe. And there is another 6-in. vacuum main connecting the multicone fly ash hoppers of three boilers. There is another duplicate piping system for the other three boilers. All four 6-in. pipes from the boilers connect to an 8-in. main. The 8-in. main proceeds to the fly ash silo. The fly ash system at the silo is similar to the bottom ash system including the primary/secondary centrifugal separators, a baghouse and a root blower. All of the ash collection riser piping is made of UCC Durite metallic alloy. The horizontal branch piping is of UCC Nuvaloy lighter weight piping material. 
A new baghouse was completed in 2004. This upgrade modified the preexisting fly ash collection system at the CHPP. Flue gas from each boiler is ducted to the new baghouse that has separate streams for each boiler. Each stream has five modules that operate in parallel, and each include bags, cages, ash hopper, inlet duct and outlet duct. Clean gas out of the baghouse modules is exhausted by new ID fans at the new baghouse structure through a stack. The separated fly ash is pneumatically conveyed to the fly ash silo (DEFC March 2005)

The ash handling system has been completely rebuilt and modified. In this effort:

1. Ash collection piping was repaired/replaced and rearranged to separate fly ash and bottom ash collection.

2. The system was converted from intermittent type to continuous process and automated.

3. New $30 \mathrm{t} / \mathrm{h}$ clinker grinders were installed and bottom ash hoppers modified.

4. Ash silo bottoms were modified from flat to funnel type.

5. To reduce fugitive dust, the existing building was extended to provide a sheltered area for fly ash loading into vehicles. This area is equipped with a ventilation system connected to the baghouse.

6. Ash discharge was equipped with a dry unloading spout that bypasses the mixers.

7. A new pulse-jet cleaned bin vent filter was installed to vent conveying air, fluidizing air, and air displaced by ash.

8. Truck loading chutes were replaced with new ones lined with low friction coefficient abrasion-resistant liners.

Ash handling system design and most of the system components were supplied by the United Conveyer Company (UCC).

\subsection{Cooling}

At the present time, cooling water for the condenser is supplied from the cooling pond. A project currently underway will replace the water-cooled condensers with Air-Cooled Condensers (ACC). This project is expected to be completed in September 2007. The turbines will be connected to the ACC during successive outages. Table 1 lists the tentative schedule. 
Table 1. ACC project schedule. (Source: Personal communication with Darrell J aeke, ACC Project Manager).

\begin{tabular}{|l|l|}
\hline \multicolumn{1}{|c|}{ Component } & \multicolumn{1}{c|}{ Completion Date } \\
\hline Air Cooled Condenser & September 30, 2006 \\
\hline Turbine \#3 Connection & October 30, 2006 \\
\hline Turbine \#4 Connection & March 17, 2007 \\
\hline Turbine \#5 Connection & September 4, 2007 \\
\hline
\end{tabular}

Each of the steam turbines: STG-3, STG-4 and STG-5 will be equipped with a three-cell, finned tube, A-frame configuration, single-pressure twostage ACC with variable speed drives. The ACC units will be housed in the new building located east from the existing plant facility. Ancillary services would include tube bundle washing system, steam heat tracing, cold weather/freeze protection, electrical, and instrumentation and control (Alaska District 20 September 2004).

\subsection{Water treatment}

The make-up water system is a reverse osmosis (RO) system that was installed in 2003. The primary source of raw water is the domestic water connection. The backup raw water source is the onsite well. Raw water is filtered in a dual-media filtration assembly consisting of three tanks, each capable of filtering $125 \mathrm{gpm}$. The filtered water is heated in a plate-andframe heat exchanger, using condensate as the heating media. The heated filtered water is de-chlorinated with sodium bisulfite, and proceeds to a single-stage, dual-train reverse osmosis unit. Each train can produce 100 gpm of treated water from a supply of 125 gpm raw water, rejecting 25 gpm. The RO treated water is disinfected in an ultraviolet disinfection unit and is stored in a new 120,000 gal treated water storage tank. The new tank is a bolted steel storage tank. The design capacity of the treatment system is 200 gpm (U.S. Army Corps of Engineers 26 June 2000).

\subsection{Electrical}

The Power Plant Electrical system includes $12.47 \mathrm{kV}$ switchgear, $4160 \mathrm{~V}$ Bus 1 and Bus 2, $2.4 \mathrm{kV}$ switchgear, $2.4 \mathrm{kV}$ motor control centers, the 480 VAC system, 120 VAC system, 125 VDC system and a backup diesel generator for lighting. The power plant transformer yard connects the power plant's electrical system to Fort Wainwright's 12.47 kV Distribution System and GVEA's system. 
Fort Wainwright's existing $12.47 \mathrm{kV}$ distribution system consists primarily of overhead pole lines and is connected to the Power Plant's $12.47 \mathrm{kV}$ switchgear. The overhead distribution system is not part of this report. The power plant is connected to the GVEA system through the power plant's switchyard. The GVEA system and any other connections to Fort Wainwright are not considered here.

The $12.47 \mathrm{kV}$ and $2.4 \mathrm{kV}$ switchgear, collectively with the $4160 \mathrm{~V}$ medium voltage switchgear, was installed in the mid 1950s. The switchgear breakers were installed with the switchgear and not replaced unless they failed. There is no record of preventative maintenance activities for the medium voltage switchgear. There are three existing spare breakers.

There are no recorded maintenance records for the medium voltage breakers, although there are spare breakers available in case one of the inservice breakers fails. Medium voltage breakers are not designed to operate reliably for decades without maintenance. At some point the breakers will fail to operate. The failures will most likely occur when the breaker is under heavy load or when a fault occurs. Breaker failure poses a risk for plant operation, plant safety and personnel safety (Fonecon with Vic Lemay and Dave Brenner 12 April 2005).

The $480 \mathrm{~V}$ system consists of two station service transformers, two $480 \mathrm{~V}$ load centers, and ten $480 \mathrm{~V}$ motors control centers.

The 120 VAC Electrical System consists of numerous transformers and panels. The condition assessment documented in the 1996 Raytheon Study (Raytheon Engineers and Constructors August 1996) concluded that the 120 VAC system has many problems and will continue to deteriorate. The study further recommends a complete replacement of the $120 \mathrm{VAC}$ system.

The 125 VDC system consists of two battery systems, 125 VDC Battery 1, and 125 VDC Battery 2. The 125 VDC system is approximately 9 years old and has not presented serious problems.

The backup lighting system consists of a diesel generator and an automatic transfer switch. When power is lost to the lighting system, the transfer switch automatically starts the diesel engine and transfers the lighting load to the generator when it is ready. The diesel generator and automatic 
transfer switch are relatively new and the plant has not experienced significant problems with their operation.

\subsection{Instrumentation and control}

The power plant instrumentation and control system mainly consists of the Westinghouse Distributed Processing Family installed around 1996. Westinghouse discontinued marketing this control system in 1997. This creates a problem for obtaining replacement parts, resulting in long lead times, high prices, and unavailability of key parts. The control system has 7000 to 8000 monitoring and control points, equally divided between the boiler and the turbine generator side. The control system is reported to have many limitations and needs to be upgraded to a current-generation control system (Alaska District 20 September 2004; Fonecon with Vic Lemay and Dave Brenner 12 April 2005; DEFC March 2005; Raytheon Engineers and Constructors. August 1996).

\subsection{Title $V$ requirements}

Fort Wainwright's Title V operating permit contains all the conditions that the installation must comply with for its stationary air pollution sources (Environmental Conservation Air Quality Operating Permit, issue Date: 14 April 2003). The operating permit contains conditions for the CHPP that include preventive maintenance and quality assurance requirements. If the preventive maintenance requirements are not performed and documented properly and according to schedule, then Fort Wainwright would be in violation of the Title $\mathrm{V}$ permit. The $\mathrm{CHPP}$ equipment affected by these conditions include the baghouse, the continuous opacity monitoring system (COMS), the continuous emissions monitoring system (CEMS), the steam flow orifice plate, and the coal scales. The intent of this section is to show the specific portions of the operating permit that lead to required components of an overall preventive maintenance plan for Fort Wainwright.

The current operating permit expires in March 2008. Part of the application process for renewing the existing permit is the creation of a Compliance Assurance Monitoring (CAM) plan. Fort Wainwright is only required to develop a CAM plan for particulate matter less than $10 \mu \mathrm{m}$ in diameter $\left(\mathrm{PM}_{10}\right)$. This is because CAM plans are only required for emissions that are reduced by an air pollution control device and the baghouse is the only air 
pollution control device used at the CHPP. The purpose of the CAM plan will be to determine and track measurements of baghouse performance that will show when the baghouse performance is beginning to slip and when it is likely that the CHPP is no longer meeting its $\mathrm{PM}_{10}$ concentration limit of 0.05 grains per dry standard cu ft. In the CHPP's current configuration, the plant will likely use measurements of pressure drop across the baghouse and opacity downstream of the baghouse as performance measurements. The CAM plan will formalize performance measurement data gathering, quality assurance, and set conditions under which Fort Wainwright needs to take action to improve baghouse performance. When instituted the CAM plan will potentially add components to the preventive maintenance plan.

\subsubsection{Baghouse requirements}

Condition 37 of the Title V operating permit states that "After installation of the baghouses the Permittee shall limit PM10 emissions to 0.05 grains per dry standard cub $\mathrm{ft}$ from Source IDs 1 through 6," where Source IDs 1 through 6 refer to the six individual boilers in the CHPP. Although the operating permit does not contain specific preventive maintenance requirements for the baghouse, the baghouse should be maintained according to the manufacturer's recommendations so that the 0.05 grains per dry standard cu $\mathrm{ft}$ concentration requirement can be sustained. The user manual includes daily, weekly, monthly, and 6-month checks of the sequence controller, filter bags, compressed air system, ash discharge system, ID fan, and dampers. Documentation of the preventive maintenance activities can help convince regulators that the baghouse system was properly maintained in the event that the baghouse has a problem meeting the particulate matter concentration requirements.

\subsubsection{Continuous opacity monitoring system requirements}

Condition 3 of the Title $\mathrm{V}$ operating permit covers visible emissions from the coal fired boilers. The condition limits exhaust effluent opacity to less than 20 percent for any 3 -minute average in any 1 -hr time period. This section of the permit contains the following specific requirements related to the preventive maintenance and quality assurance of the COMS:

3.2 Monitor, record, and report visible emissions by operating a COMS as follows: 
c. Check the zero (or low level value between 0 and 20 percent of span value) and span (50 to 100 percent of span value) calibration drifts at least once daily in accordance with a written procedure meeting performance specification 1, 40 CFR 60, Appendix B

3.4 Conduct performance audits on the COMS as follows:

a. For a COMS that was new, relocated, replaced, or substantially refurbished on or after April 9, 2001, perform an audit that includes the following elements, as more completely described in Section 13, of the Department's Performance Audits for COMS, adopted by reference in 18 AAC 50.030, at least once in each 12 months:

(i) optical alignment;

(ii) zero and upscale response assessment;

(iii) zero compensation assessment;

(iv) calibration error check; and

(v) zero alignment assessment;

b. For a COMS that was new, relocated, replaced, or substantially refurbished before April 9, 2001, perform the same audits required under Condition 3.4a, except that Conditions 3.4a(i) through $3.4 \mathrm{a}$ (iv) must be performed at least quarterly;

Condition 94 of Section 13 provides much greater detail about specific requirements for each element of the COMS performance audit. Proper documentation of the daily zero and span checks and the annual performance audits are required to stay in compliance of these operating permit conditions. The Model OPM 2001 opacity monitor manual contains a section on preventative maintenance and suggested spare parts. A quality assurance plan is under development for the COMS to describe all activities required to maintain compliance with the operating permit. The operating permit also contains provisions for using EPA Method 9 for visually determining opacity when the COMS has been out of operation for more than $24 \mathrm{hrs}$ or after a failed performance audit. Method 9 requires training renewal every 6 months to "recalibrate" their visual capability for determining opacity. 


\subsubsection{Continuous emissions monitoring system}

Condition 29 of the Title $\mathrm{V}$ operating permit requires that Fort Wainwright:

Calibrate, certify, operate, and maintain, in accordance with 40 CFR 60

Appendix B and Appendix F a continuous carbon monoxide (CO) and

oxygen (O2) emission monitoring systems (CEMS) to measure $\mathrm{CO}$ and

O2 emissions in the exhaust of Source IDs 1 through 6. The Permittee

shall continuously monitor, compute, and record $\mathrm{CO}$ emissions based

upon carbon monoxide and oxygen exhaust concentration measure-

ments.

The CEMS information is used to calculate CO emissions on a daily and annual basis. Condition 29 also requires careful documentation of CEMS data and Condition 29.2 states that the documentation must include

the date, time, and duration for which the continuous monitoring system required under Condition 29 is out-of-bounds, not recording data, or inoperable. Report each periodic Cylinder Gas Audit and Relative Accuracy Test Audit results conducted during the reporting period.

Fort Wainwright has carefully documented all maintenance and quality assurance requirements in a quality assurance plan (Fort Wainwright, AK March 2004). This plan includes a daily checklist based on the manufacturer's recommended preventative maintenance procedures. Continued adherence to this plan will allow Fort Wainwright to maintain compliance with Condition 29 of the operating permit.

\subsubsection{Steam flow orifice plate requirements}

Condition 35 of the Title V operating permit states that:

The Permittee shall limit the monthly-average steam production to 150,000 pounds per hour for each of six (6) boilers, Source IDs 1 through 6 until a source test demonstrates compliance with emission standards at a higher load in accordance with Condition 5.2 and the department approves operation at the higher load.

This condition also contains the following specific requirements. 
35.1 Calculate and record the average daily steam production rate $(\mathrm{lb} / \mathrm{hr}$ ) based on the hours of operation per day and steam production readings recorded at no less than 10-minute intervals.

35.2 Calculate and report in the Operating Report required by Condition 75 , the monthly average steam production rate $(\mathrm{lb} / \mathrm{hr})$ for each of the past 6 months for each of Source IDs 1 through 6 .

35.3 Report as excess emissions under Condition 73 for any period in which operations exceed the limits in Condition 35.

Condition 5.3 also covers the measurement and recording of steam production. This condition contains the following sections:

a. Operate and maintain a device to measure and record steam production in accordance with the manufacturer's written requirements and recommendations;

b. Except during breakdowns, repairs, calibration checks, and zero and span adjustments of the device, complete at least one cycle of sampling and analysis for each successive 15-minute period of boiler operation. From this data, calculate and record the average steam production rate for successive 1-hr periods. Maintain this data at the facility and make it available to the Department on request;

c. Within 1 year after the effective date of this permit and at such times as the Department may require, determine the relative accuracy of each monitoring device required by Condition 5.3a; and

d. Keep sufficient written records to show compliance with the requirements of Condition

5. In addition, keep records of the date and time identifying each period during which a device required by this permit is inoperative, except for zero and span checks, and records of the nature of device repairs and adjustments; on request of the Department, submit copies of the records.

Condition 5.4 states that The Permittee shall

a. Submit a report in accordance with Condition 73 whenever any of the following situations occur:

(i) when steam production exceeds a permit limit; 
(ii) when the results of a source test exceed the particulate matter emission limit; and

(iii) if a steam production monitoring device malfunctions or becomes inoperable for four or more consecutive hours; in the report, identify the boiler, the cause of failure, and the anticipated time required to repair the device;

To maintain compliance with these conditions, the steam flow orifice plate must be maintained. These plates can be susceptible to erosion, which could change the measurement characteristics and pressure drop versus steam flow calibration. Therefore regularly scheduled inspections of the orifice plate should be added to a preventive maintenance plan for the CHPP.

\subsubsection{Coal scale requirements}

Condition 27 of the Title $\mathrm{V}$ operating permit requires that Fort Wainwright "Limit the annual coal consumption to a cumulative total of 336,000 tons per consecutive 12-month period for Source IDs 1 through 6.” This condition also contains the following specific requirements.

27.1 Monitor and record the cumulative total monthly coal consumption for each of Source IDs 1 though 6, and calculate and record the cumulative 12 consecutive month total coal consumption.

27.2 Report in the Operating Report required by Condition 75, the cumulative monthly and 12 consecutive month total coal consumption for Source IDs 1 through 6.

27.3 Report in the Excess emission Report required by Condition 73, when the limits of Condition 27 are exceeded and identify the boiler.

To maintain compliance with Condition 27, the coal scales must be calibrated according to the manufacturer's recommendations. Fort Wainwright has been calibrating the scales on a regular basis. It is important however to document the calibration results in case there are ever questions about compliance with Condition 27. 


\section{Overview of Existing Maintenance Management Program}

\subsection{Current program procedure and issues}

From 27 to 31 March 2006, a site visit was conducted to fully evaluate the current maintenance program in place at the Fort Wainwright CHPP. The site evaluation consisted of program review, records review, staff interviews, and equipment inspections. This chapter gives an overview of the plant maintenance program and identifies important issues.

\subsubsection{Description of procedure}

The plant maintenance program is an informal, mostly reactive system that addresses issues only when they impact operations. Since each power plant is unique, historical maintenance/repair records are the singlemost important input in establishing future maintenance and repair requirements. The lack of such records at the CHPP makes it very difficult to establish a baseline for future requirements.

Reactive maintenance actions are noted in two logs. One log is for mechanical items, and one is for Electrical, Instrumentation, and Controls $(\mathrm{EI} \& \mathrm{C})$ items. Appendix A ( $\mathrm{p} 78$ ) gives examples of these two logs. The EI\&C items are handled by the EI\&C technicians on a self-prioritized basis. At the beginning of each shift, the Maintenance Lead reviews the mechanical log and issues work assignments to the mechanical maintenance technicians. The shift foreman for the operations shift working day shift will review the logs and provide input as to which issues are most pressing and check on the progress of previous issues. When an item has been corrected, the correction is sometimes entered in the appropriate log.

The system lacks a written procedure to document how maintenance actions are to be identified, assigned, tracked, and who is responsible for the items. 


\subsubsection{Description of issues}

\subsubsection{System is reactive}

The maintenance system is almost completely reactive. No written procedures identify required actions and responsibilities. (A written procedure would also identify and include the records that needed to be kept.) Proper maintenance records are a very important part of any maintenance program. They allow the tracking of problems to identify patterns and provide data to analyze equipment maintenance costs versus repair or replacement costs to make intelligent decisions on the disposition of equipment.

The reactive maintenance logs were analyzed to show the systems and equipment that required the most attention between February 2005 and March 2006 (14 months). This time period was used strictly due to the availability of the logs from the plant personnel. Unfortunately, all reactive maintenance actions that are being performed are apparently not being recorded in the logs. Figure 3 shows the number of maintenance entries for each of the following major systems.

- boiler systems

- steam turbine generators and cooling system

- feedwater and condensate systems

- steam system

- coal handling system

- ash handling system

- water treatment system

- electrical and instrument and controls system

- miscellaneous systems and items.

Figures 4 to 11 show a breakdown of each system to show the equipment in each system that produces the most maintenance actions, and Table 2 lists a breakdown of maintenance entries by subsystem from February 2005 to March 2006). 


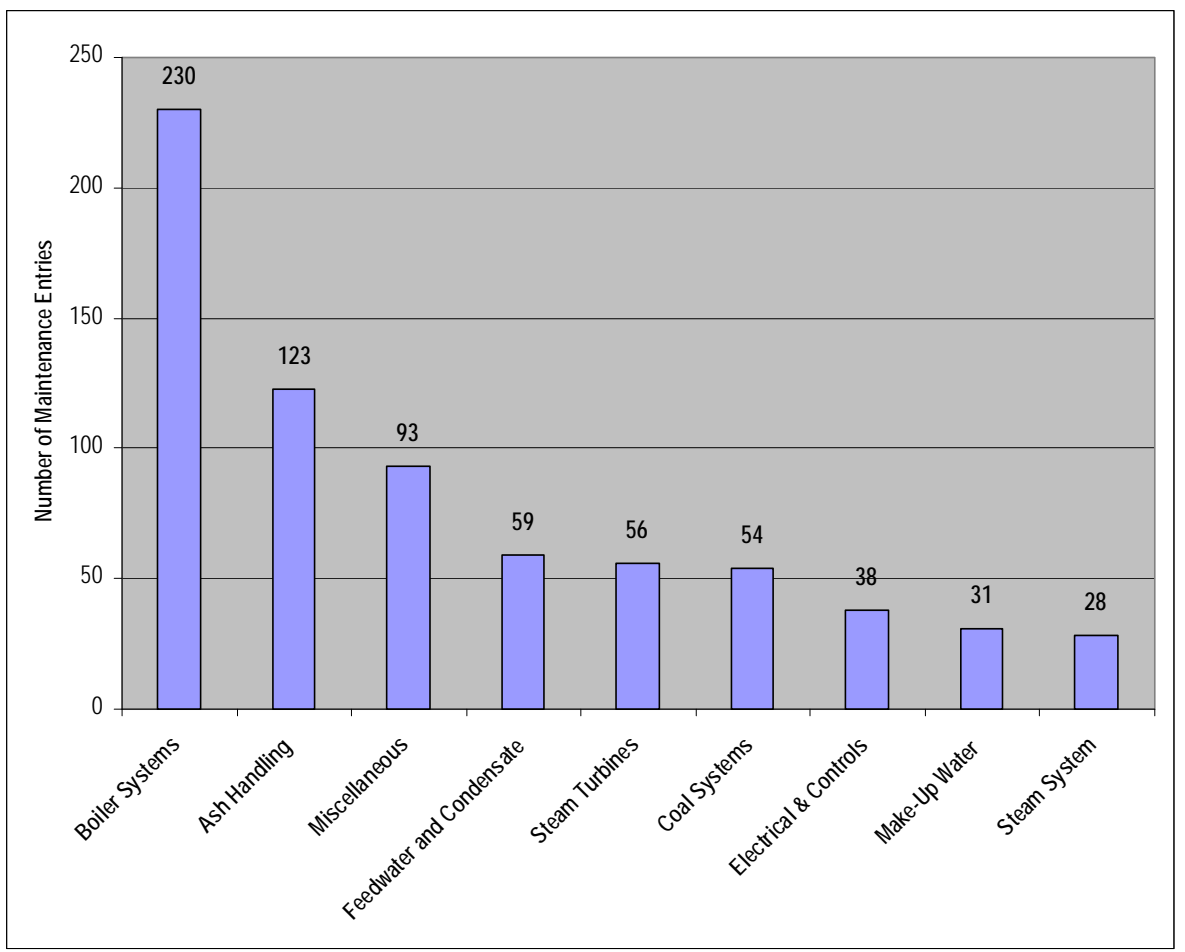

Figure 3. Maintenance entries by system (2/05 - 3/06).

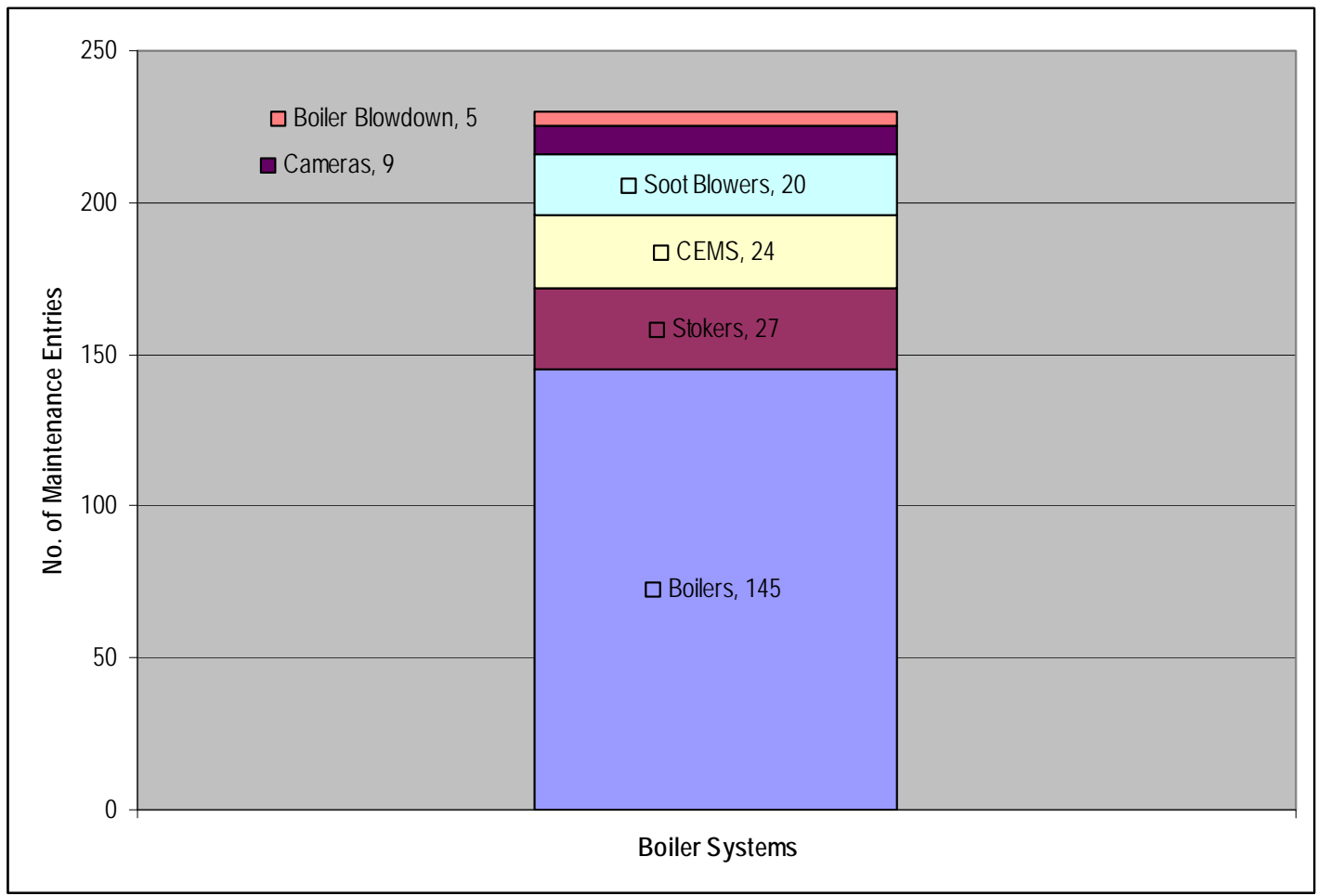

Figure 4. Boiler systems maintenance entries (2/05 - 3/06). 


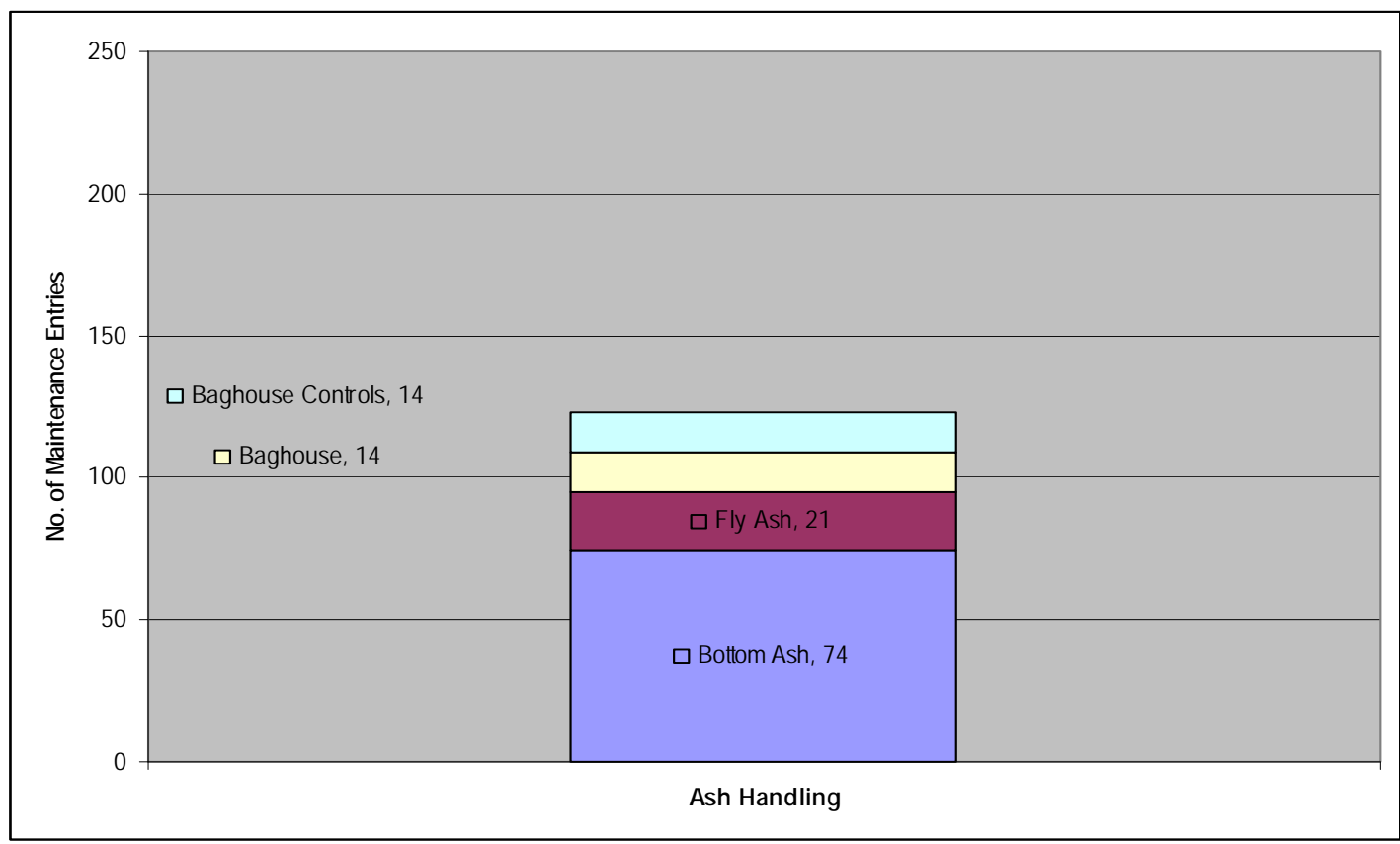

Figure 5. Ash handling maintenance entries (2/05 - 3/06).

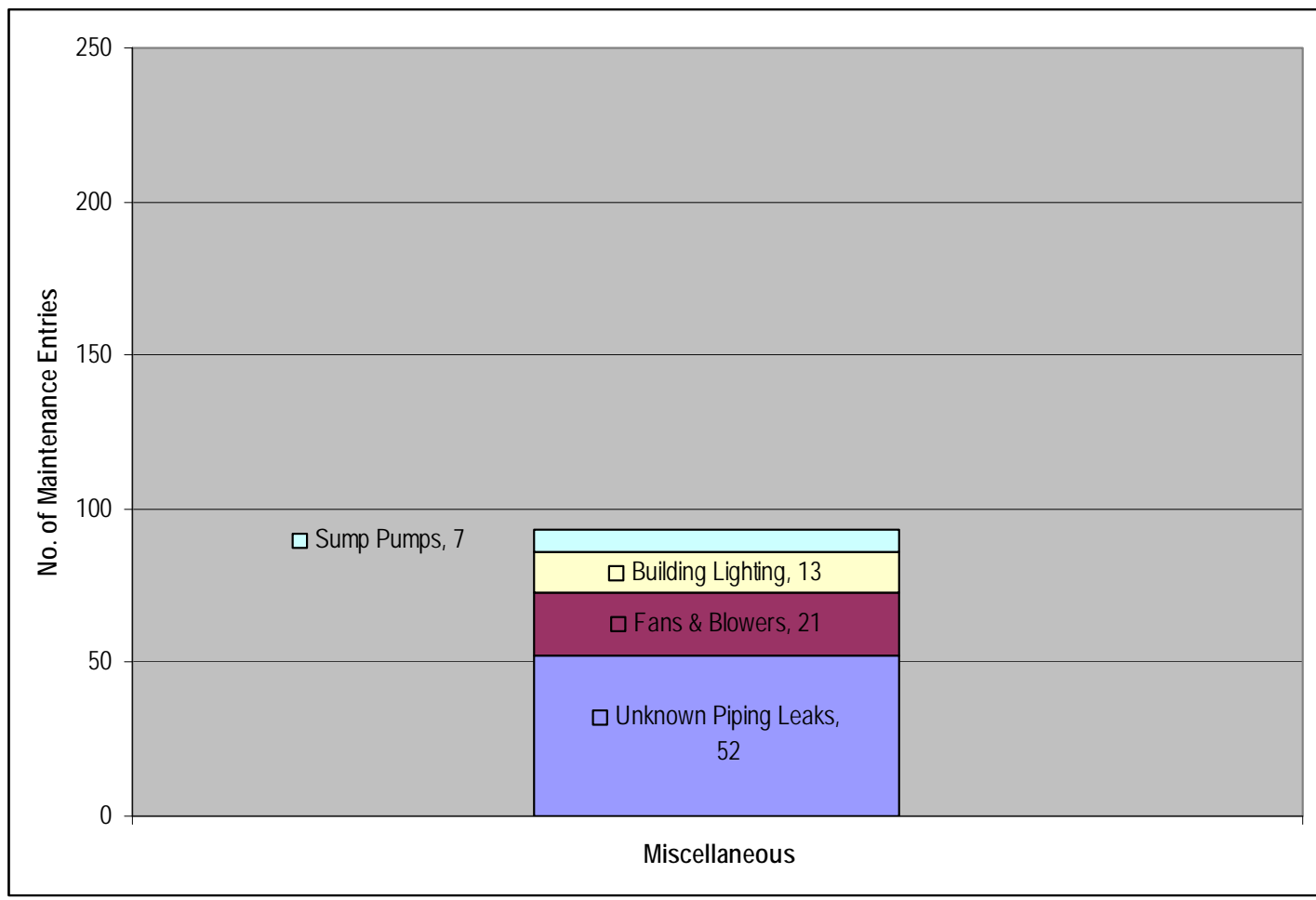

Figure 6. Miscellaneous maintenance entries (2/05 - 3/06). 


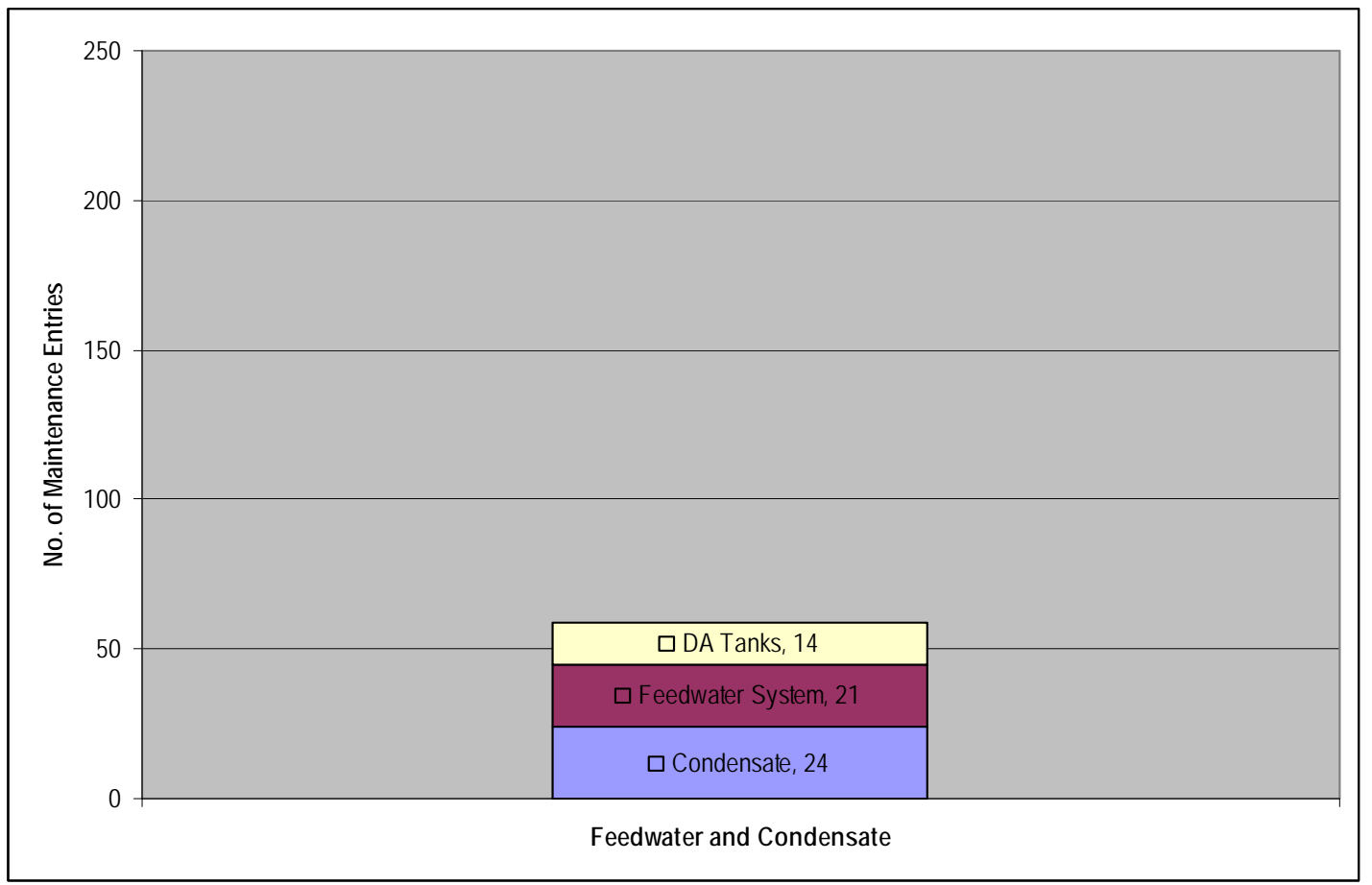

Figure 7. Feedwater and condensate maintenance entries (2/05 - 3/06).

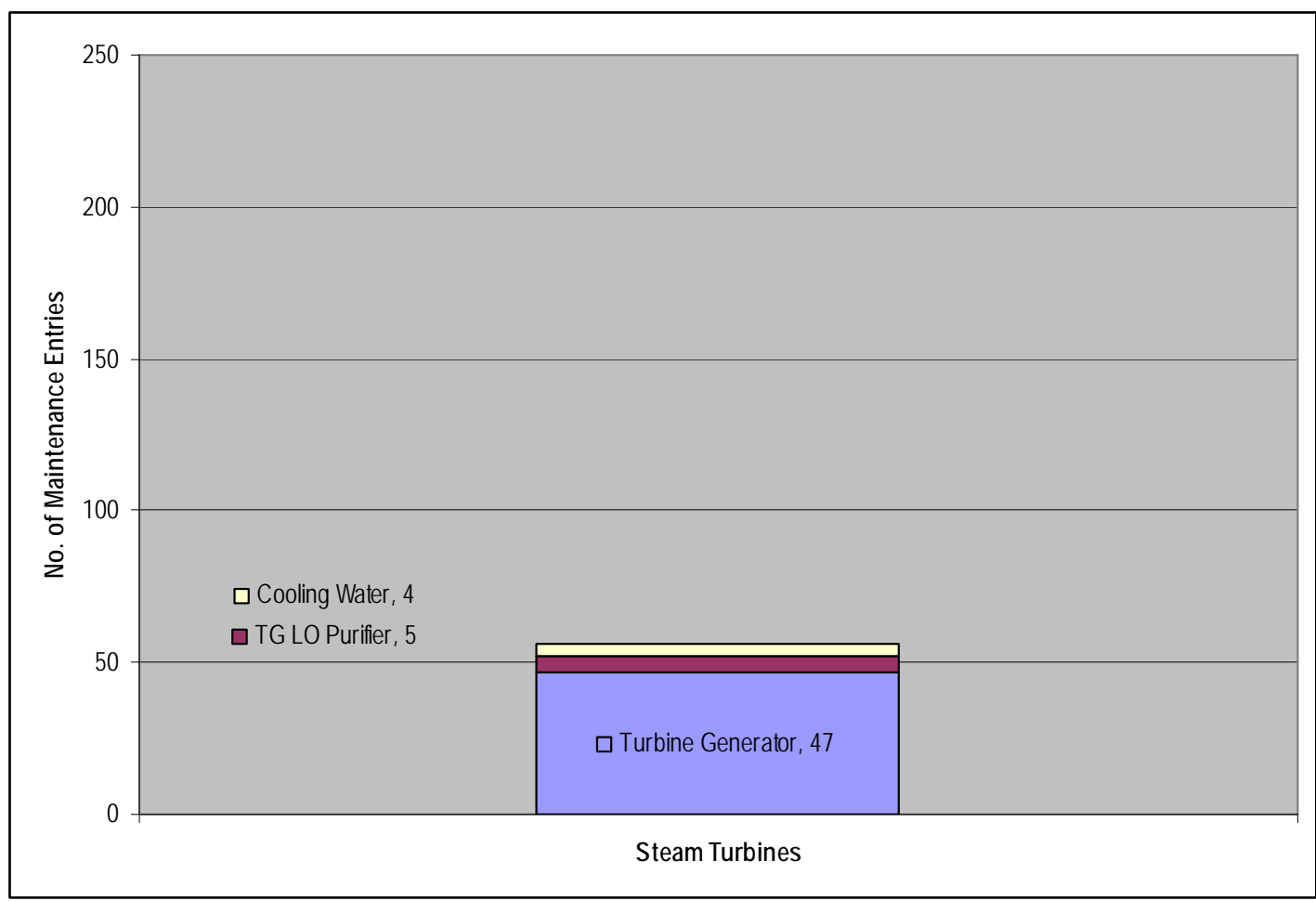

Figure 8. Steam turbines maintenance entries (2/05 - 3/06). 


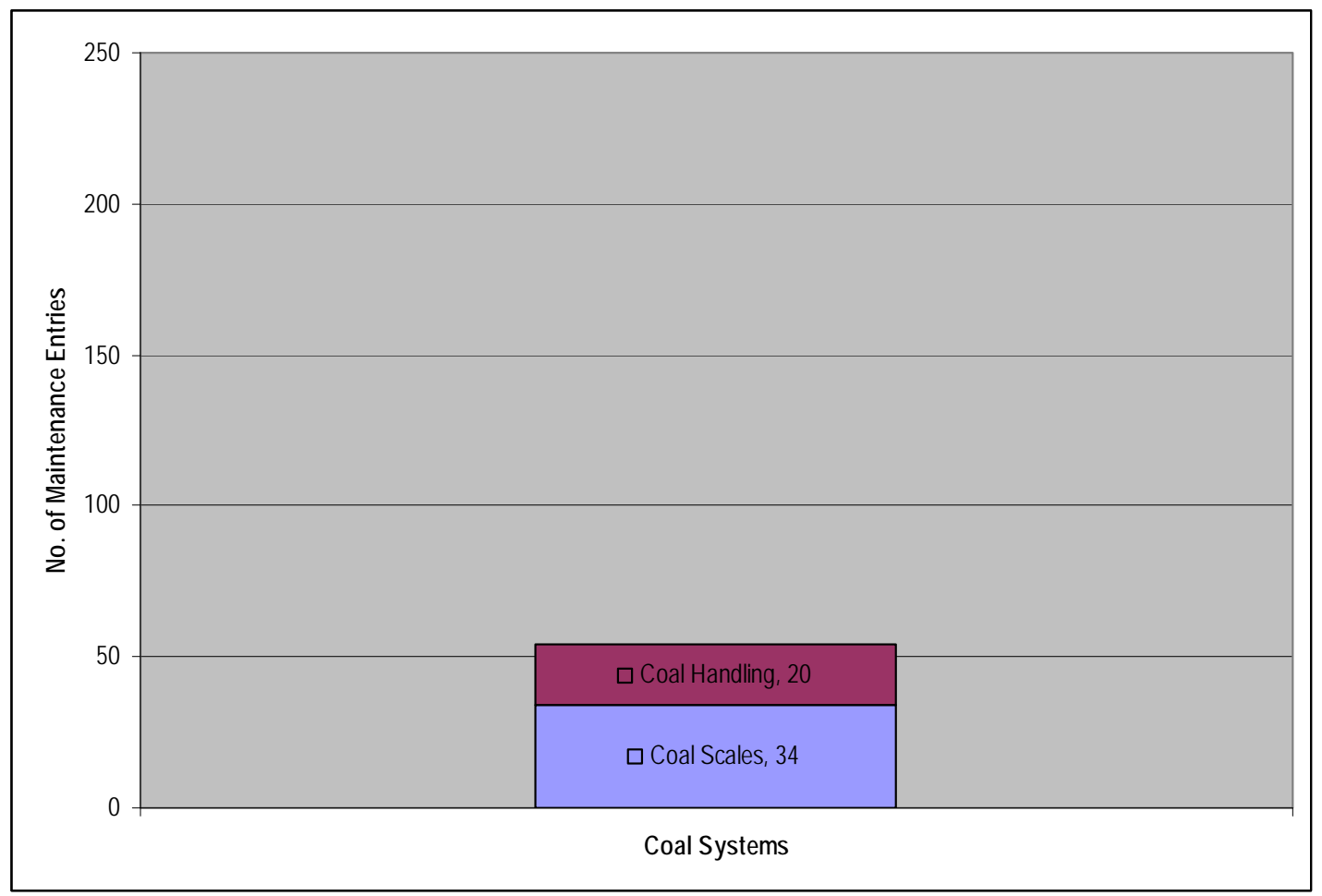

Figure 9. Coal handling maintenance entries (2/05 - 3/06).

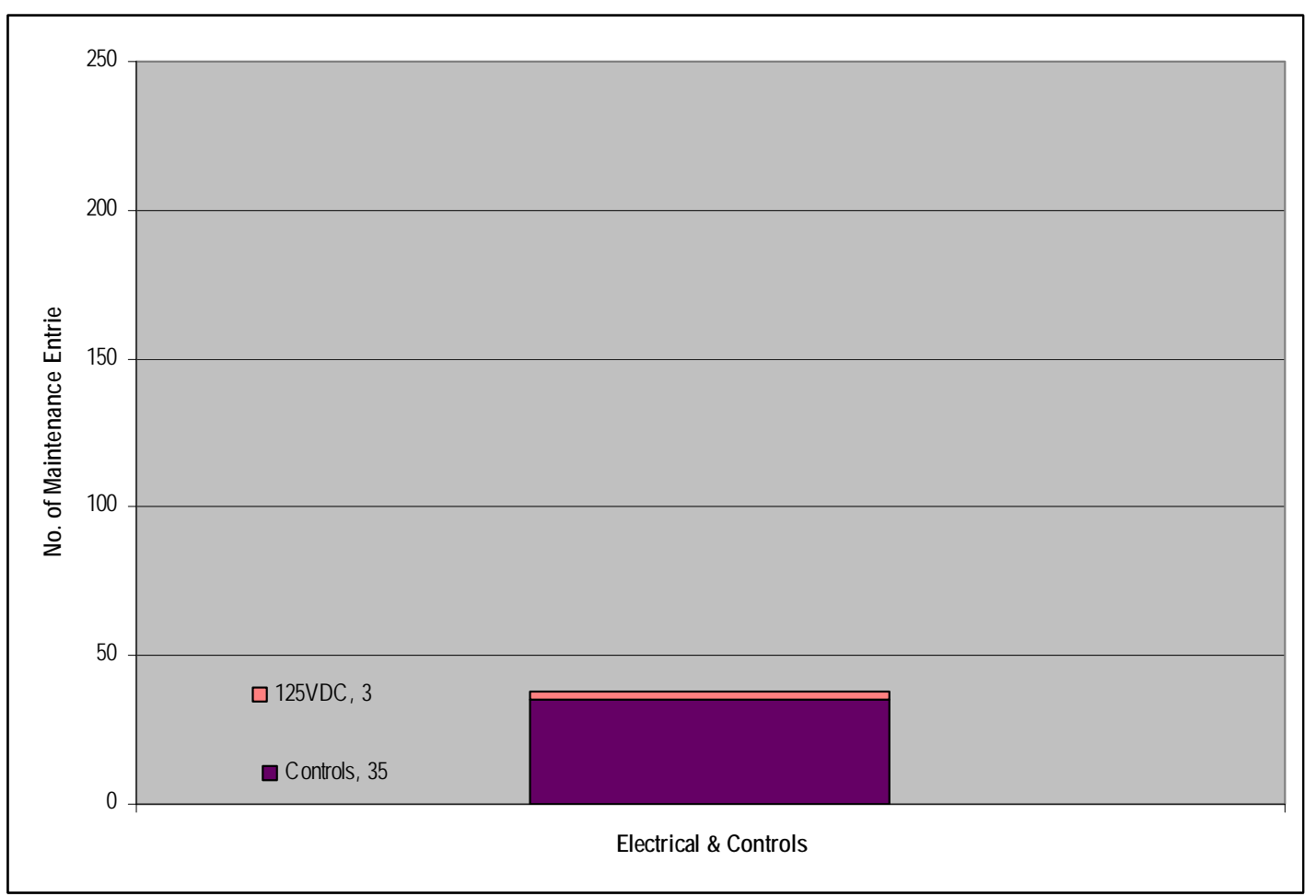

Figure 10. Electrical and controls maintenance entries $(2 / 05-3 / 06)$. 


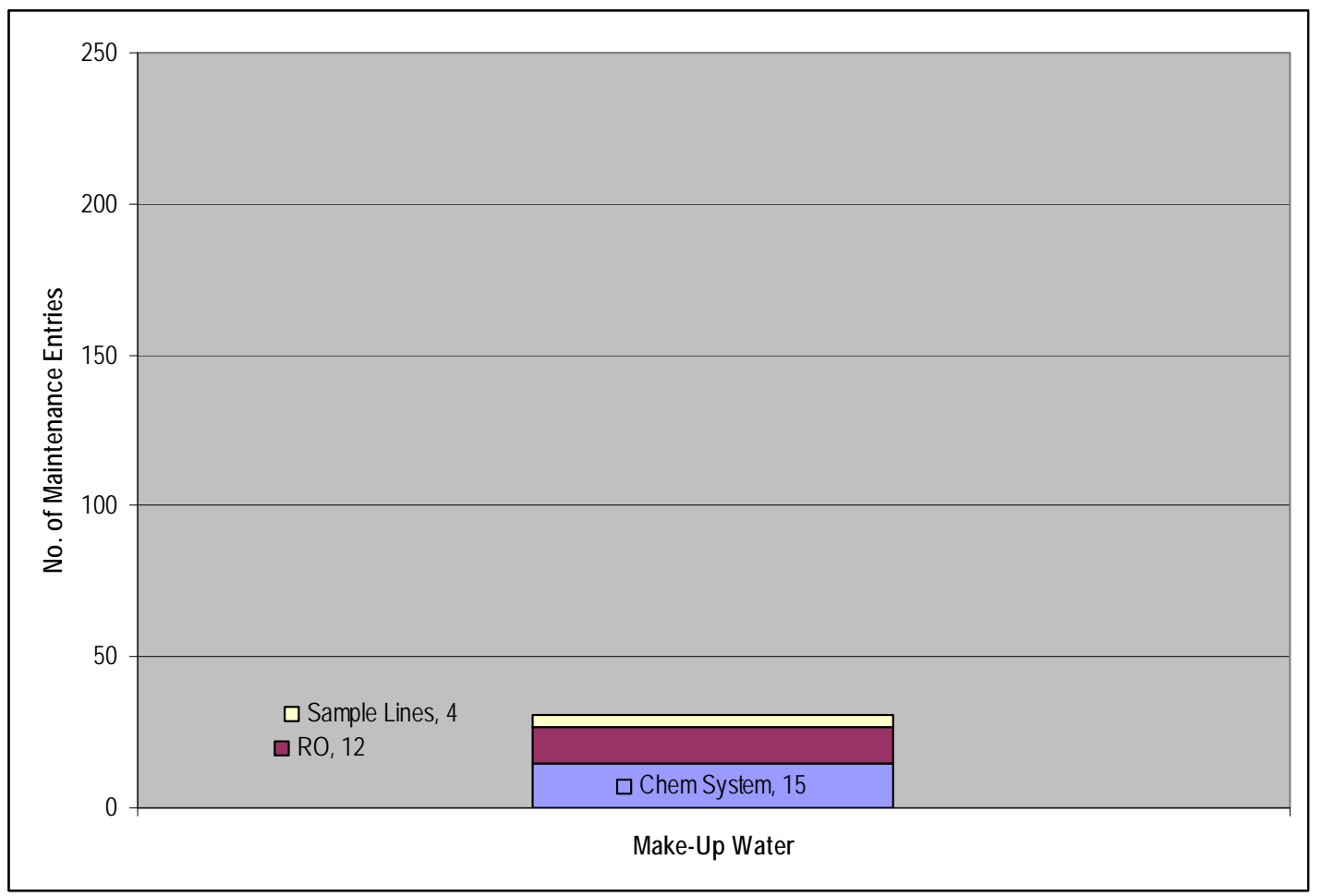

Figure 11. Make-up Water Maintenance Entries (2/05 - 3/06).

Table 2. Maintenance entries breakdown by subsystem (2/05 - 3/06).

\begin{tabular}{|l|l|r|c|}
\hline \multicolumn{1}{|c|}{ System } & \multicolumn{1}{|c|}{ Subsystem } & Number of Entries & Percentage \\
\hline Boiler & & 230 & $32 \%$ \\
\hline & Boilers & 145 & $20 \%$ \\
\hline & Stokers & 27 & $4 \%$ \\
\hline & CEMS & 24 & $3 \%$ \\
\hline & Soot Blowers & 20 & $3 \%$ \\
\hline & Cameras & 9 & $1 \%$ \\
\hline & Boiler Blowdown & 5 & $1 \%$ \\
\hline & & 123 & $17 \%$ \\
\hline & Bottom Ash & 74 & $10 \%$ \\
\hline & Fly Ash & 21 & $3 \%$ \\
\hline & Baghouse & 14 & $2 \%$ \\
\hline Miscellaneous & Baghouse Controls & 14 & $2 \%$ \\
\hline & & 93 & $13 \%$ \\
\hline & Unknown Piping Leaks & 52 & $7 \%$ \\
\hline & Fans and Blowers & 21 & $3 \%$ \\
\hline & Lighting & 13 & $2 \%$ \\
\hline Feedwater and Condensate & Sump Pumps & 7 & $1 \%$ \\
\hline & & 59 & $8 \%$ \\
\hline & Condensate & 24 & $3 \%$ \\
\hline & Feedwater & 21 & $3 \%$ \\
\hline Steam Turbines & DA Tanks & 14 & $2 \%$ \\
\hline & & 56 & $8 \%$ \\
\hline & Turbine Generator & 47 & $7 \%$ \\
\hline & TG LO Purifier & 5 & $1 \%$ \\
\hline
\end{tabular}




\begin{tabular}{|l|l|c|c|}
\hline \multicolumn{1}{|c|}{ System } & \multicolumn{1}{|c|}{ Subsystem } & Number of Entries & Percentage \\
\hline & Cooling Water & 4 & $1 \%$ \\
\hline Coal Systems & & 54 & $8 \%$ \\
\hline & Coal Scales & 34 & $5 \%$ \\
\hline & Coal Handling & 20 & $3 \%$ \\
\hline Electrical and Controls & & 38 & $5 \%$ \\
\hline & Controls & 35 & $5 \%$ \\
\hline & 125 VDC & 3 & $0 \%$ \\
\hline Make-Up Water & & 31 & $4 \%$ \\
\hline & Chem System & 15 & $2 \%$ \\
\hline & RO & 12 & $2 \%$ \\
\hline & Sample Lines & 4 & $1 \%$ \\
\hline Steam System & Steam System & 28 & $4 \%$ \\
\hline & & & \\
\hline Total & All Areas & 712 & $100 \%$ \\
\hline
\end{tabular}

The data listed in Table 2 show that the boilers are by far the highest maintenance action on the list, as evidenced by the greatest number of maintenance entries. Note that these counts represent the problems that were recorded in the maintenance log books, not all the maintenance actions that were performed during that time period. Plant personnel indicated that some items are passed to the maintenance department by word of mouth and are completed with no recordkeeping.

\subsubsection{Training program is nonexistent}

There is no continuing training of the maintenance department. In the modern world of continuously improving technology and techniques, continuous training of technicians is essential to ensure that high quality maintenance actions are being performed. OEM training is especially important to educate the maintenance staff on new equipment and refresher training for infrequent or large scale maintenance actions. A formal qualification and training program for the maintenance department would allow training to be tracked and would ensure that all technicians had a common base of knowledge. All technicians bring various specialized skills to the work environment. The CHPP should take advantage of those skills by assessing them and implementing a cross training program among the technicians. The maintenance department staff should also learn the various operations watch stations as part of the continuous training program. The knowledge of how the plant operates is invaluable in finding the root causes of equipment problems. Plant Management indicated a desire to begin training maintenance technicians in plant operations, but stated personnel shortages kept them from starting any kind of training program. 


\subsubsection{Plant documentation is not accessible}

Currently, all plant manuals and drawings are kept locked on the ground floor in a room outside of the EI\&C shop. Plant personnel do not have access to the documentation. Many of the interviewed personnel expressed surprised to find out that a room even existed that contained the plant manuals and drawings. Access to documentation is of the utmost importance to maintenance personnel to troubleshoot and repair equipment per manufacturer's instructions.

\subsubsection{No formal maintenance planning or budget}

The Maintenance Department currently has no formal budget that breaks down expenditures into a usable format. The proper allocation of resources requires preplanning and a solid budget. The listing of expenditures and planned expenditures allows the staff to track where money is going and if it is being used in the best possible manner. The Operations and Maintenance budget that was provided to the assessment team was the budget estimate for Fiscal Year 2005. The budget shows the labor costs for Fiscal Year 2005 and a few additional charges for tools, replacement materials, annual facility charge, and support utilities cost. The estimates are based on a percentage of the value of the facility. The line items are not broken down in any meaningful way relating to the maintenance of the plant. Table 3 lists these expenditures and the O\&M labor costs.

\subsubsection{Limited long range maintenance planning}

The CHPP currently employs limited long range planning of maintenance and equipment resources. Some planning was done in conjunction with CERL (Brown 28 March 2006), but there is no evidence that this plan is being followed or is anything more than a wish list. The 1996 Raytheon study recommended the implementation of a comprehensive NonDestructive Evaluation (NDE) program for critical CHPP equipment and systems. This program was never implemented (Raytheon Engineers and Constructors August 1996). Equipment overhauls and major maintenance actions are performed when equipment performance has degraded to a point where it is no longer useful or when a catastrophic failure has occurred. Long range planning has numerous advantages especially when coupled with a preventative maintenance plan. The long range plan can also be used to build a meaningful budget. 
Table 3. CHPP O\&M budget 2005.

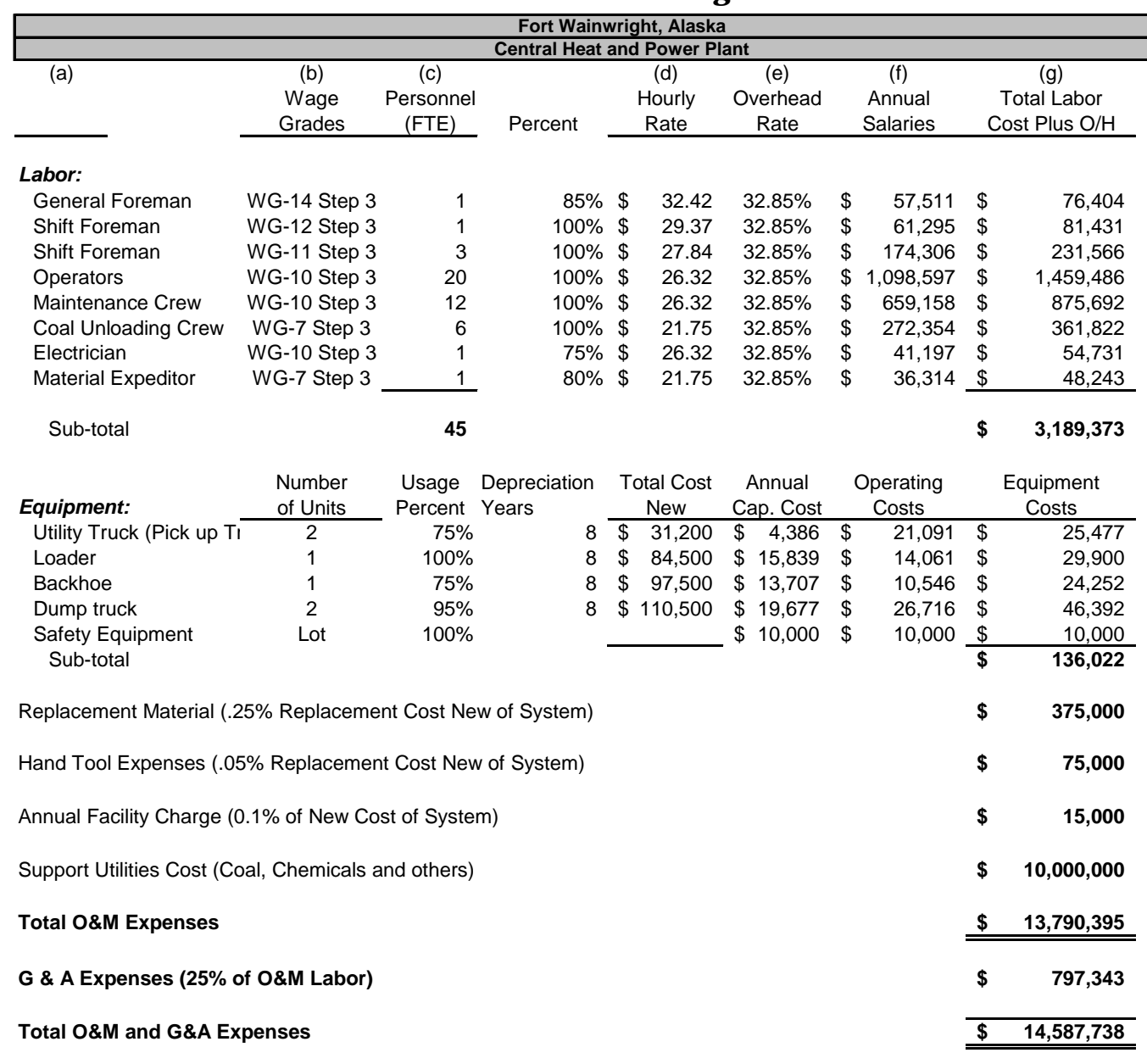

Notes:

1.) Labor hour rates from Alaska area Wage Rate Schedule at www.cpms.osd.mil/wage/...

2.) $\mathrm{FTE}=2,087 \mathrm{hrs} /$ year per OMB Circular A-76 guidance.

3.) Labor overheard rate per OMB A-76 guidance.

4.) Financed over depreciation life @ 10.0\%

5.) Equipment operating cost $\$ 8.45 / \mathrm{hr}$, five days a week and $80 \%$ availability

Note: The above labor includes all authorized positions including those positions not filled/

\subsection{Issues not directly related to the study}

Several important issues, not directly related to the scope of the commissioned study, were uncovered during the evaluation and are briefly recorded here. These issues include the safety program and plant operations.

\subsubsection{Safety program}

The safety program is not enforced. The study team witnessed numerous unsafe acts including moving hot coals from an operating boiler to start another boiler without gloves, face protection, or eye protection. The team also witnessed plant personnel using a portable drill without eye protec- 
tion. The Personal Protective Equipment (PPE) available is not always in serviceable condition. It is recommended that an in-depth safety audit be conducted to determine shortcomings in the written safety program and in the training of plant personnel in all aspects of safety.

\subsubsection{Plant operations- training and procedures}

The plant operators are a dynamic group of individuals that all bring their own unique set of experiences and training to the operation of the CHPP. However, there is no set training and qualification program that forms a baseline of knowledge for all plant operators. During staff interviews, it was noted that operators had differing levels of knowledge about plant operations. Several maintenance technicians noted that the operators do not understand the function of some of the plant equipment and will erroneously note items as malfunctioning when they are performing infrequent functions. A formalized training and qualification program is recommended for the operators to ensure that all operators have a baseline of knowledge on plant systems and operations. Army Regulation 420-49 requires:

a. Operator training and certification. Utility operators will be trained and certified in accordance with applicable existing Federal, State, local, or host nation standards. In the absence of Federal, State, local, or host nation certification requirements for boiler plant operators, the Fourth Class Power Engineer Certification Program of the National Institute for the Uniform Licensing of Power Engineers, Inc., will be the governing requirement. (Utility Services 19 September 2005)

This requirement explicitly states that all operators will be trained and certified to the state requirements. Alaska does not require that boiler operators be licensed therefore the operators must meet the certification requirements for a Fourth Class Power Engineer by the National Institute for the Uniform Licensing of Power Engineers, Inc.

Another issue related to plant operations is the lack of formalized normal operating and emergency operating procedures. For example, it was noted that one of the operators had stored a set of operating procedures in the water treatment laboratory, ostensibly so they would not become lost or damaged. Interviews revealed that most operators were unaware that operating procedures even existed. Operations knowledge is handed down from senior operators to junior operators by word of mouth. What the sen- 
ior operator teaches is strictly at the discretion of the senior operator. While all the senior operators are extremely knowledgeable on the plant, not all are equally effective at communicating that knowledge. The lack of emergency operating procedures at the plant results in an environment where a small problem can cascade into a large problem due to operator inaction or incorrect action. It is recommended that both Normal Operating and Emergency Operating procedures be developed and incorporated into the Training and Qualification program (recommended above).

\subsection{Current scheduling methodology}

Plant maintenance staff are currently attempting to create a time-based preventative maintenance system. The program is very small and is not formalized with a procedure or record keeping requirements. The scheduling of these items is on a routine basis without planning around future outages or other events. The schedule of items is noted in Section 3.6 (p 31).

\subsection{Major maintenance and overhaul assessment}

There is currently no overhaul or outage schedule. While it is understood that the plant cannot ever completely shutdown, maintenance outages can be performed on a rolling basis along with the boilers and turbines. Work is not currently tracked by management. There is no master list of repair items for equipment that needs to be completed during the next equipment shutdown or overhaul.

\subsection{Current maintenance tools and equipment assessment}

Interviews with the maintenance staff indicate that there are enough hand tools, and they are in serviceable condition. Interviewed EI\&C technicians stated a desire for updated test equipment. Specific equipment was not requested by the technicians and they did not elaborate about what they would like or what was deficient with the current equipment.

\subsection{Preventative maintenance schedule review}

The mechanical maintenance department has created a lubrication schedule to ensure all plant equipment is lubricated monthly. The lubrication schedule covers some of the recommended maintenance actions for 
pumps and motors throughout the plant. Appendix B (p 80) includes the schedule. The Maintenance Lead stated that the list is constantly being revised and expanded. The list does not cover all equipment at the plant or all maintenance actions that need to be performed.

The EI\&C maintenance department performs weekly battery water level checks for the emergency $125 \mathrm{VDC}$ battery system and performs cleaning and inspections on plant control cabinets and switchgear on a time available basis.

\subsection{Review of manning}

This review of manning has been divided in a review of current staffing and contracted services.

\subsubsection{Current staffing}

The EI\&C department is officially supervised by the Maintenance Lead, but due to the complex nature of the tasks performed by the EI\&C technicians, they self prioritize the work. The Maintenance Lead has a mechanical maintenance background and would be better suited to the supervision of the mechanical maintenance technicians. The addition of an EI\&C supervisor would greatly enhance the department.

Currently, no long-range planning is being performed with respect to major maintenance and overhauls. The current practice is to run equipment to failure before an overhaul will be performed. Due to funding limitations, the CHPP is unable to establish an effective preventative maintenance program. Plant Management states that the staff understands the need for a preventative maintenance system and is capable of implementing a system if the effort were properly funded (Personal communication with Pat Driscoll and Mike Meeks). Table 4 lists current manning levels for the maintenance department.

Table 4. Current manning vs. authorized manning.

\begin{tabular}{|l|c|c|c|}
\hline \multicolumn{1}{|c|}{ Position } & Current & Authorized & Understaffing \\
\hline El\&C Technician & 3 & 5 & 2 \\
\hline Mechanical Technician & 6 & 6 & 0 \\
\hline Lead Maintenance Tech & 1 & 1 & 0 \\
\hline
\end{tabular}


Table 5. Recommended manning additions.

\begin{tabular}{|l|c|l|}
\hline Title & Number & Currently Authorized \\
\hline Maintenance Manager/ Planner & 1 & No \\
\hline El\&C Supervisor & 1 & No \\
\hline El\&C Technicians & 2 & Yes, but not filled \\
\hline Mechanical Maintenance Technicians & 2 & No \\
\hline
\end{tabular}

The authorized staffing levels are inadequate to perform all necessary work that will be required with a preventative maintenance program. Table 5 details manning recommendations. The EI\&C department is undermanned by two technicians, based on authorized vs. actual staffing levels. The quality of work performed by the EI\&C technicians has suffered due to that shortage. The lack of supervision is also negatively impacting both the quality and quantity of work being performed by the EI\&C technicians. All major maintenance and overhaul work is subcontracted to qualified vendors. The lack of tracking of maintenance issues and lack of pre-planning of outages and overhauls has also had a negative impact on the condition of the equipment. For example, an operator relayed information to the evaluation team about a temperature input to the Instrumentation and Control system for one of the bearings on STG-5. The input had failed prior to the turbine overhaul in 2002. The problem was not repaired during the overhaul and still had not been corrected by March 2006 (Personal communication with operator).

\subsubsection{Contracted services}

Large and specialty maintenance actions are contracted to outside service providers. The 1995 ZBA Non-Destructive Evaluation (NDE) study is an example of large maintenance being awarded to outside contractors, because of the size and complexity of the work. The lack of records made thorough evaluation of this area impossible.

\subsection{The Army's TM 5-650 program}

The Army already has a simple program that is available for implementation at every CHPP in the Army inventory published in Technical Manual (TM) 5-650, Repairs and Utilities: Central Boiler Plants chapter 5. this preventive maintenance program relies on periodic maintenance of equipment to extend equipment life and increase reliability. (Appendix $\mathrm{C}$ to the TM contains the procedure.) The program provides an Army stan- 
dard form (DA 4177) to record the applicable preventative maintenance actions for each piece of equipment on one side. The other side of the form contains space to record the dates each item was performed and by whom. These forms allow for the tracking of each maintenance action and provides for a level of accountability since the person performing the maintenance action is recorded. An example of a completed DA 4177 card is found in Appendix $\mathrm{C}$ on page 5-4. The procedure also provides recommended maintenance actions for various pieces of equipment throughout the central heating plant. The system relies on inspections to detect problems before they cause a forced outage, but does not deal with predictive functions at all. The current program at the plant is similar to this, but is not as extensive or formalized. The lack of a written procedure precludes having any accountability in the system. Accountability is an essential element to properly manage any program.

\subsection{Summary of issues}

Outlined below is a summary of issues related to this task and other issues not directly related to the task.

\subsubsection{Summary of issues}

The following list summarizes the major issues with the current maintenance system:

1. The existing maintenance system is solely reactive.

2. There is no written procedure documenting the maintenance program implementation. The lack of a formal written procedure hinders the maintenance of equipment by not standardizing how items are reported, tracked, and scheduled.

3. Maintenance logs do not have a formal tracking system.

4. Training of maintenance staff is lacking.

5. There is a general lack of records for maintenance activities.

6. Access to equipment OEM manuals and drawings needs to be improved. In fact, their very existence needs to be communicated.

7. No formal maintenance budget exists.

8. There is limited long range maintenance planning. 


\subsubsection{Summary of issues not related to study}

The following list summarizes the issues that the study team observed during the site visit, but that are not directly related to this study:

1. Safety Program is lacking.

2. Plant Operations needs a formal Training and Qualification Program. 


\section{New Technologies}

The chapter describes new technologies (diagnostic tools) that are required for, or will greatly enhance, the implementation of the recommended RCM program. The following sections discuss the following new technologies:

- Computerized Maintenance Management System (CMMS)

- Thermal Imaging Program

- Vibration Analysis Program

- Oil Analysis Program

- Non-Destructive Evaluation (NDE) Program.

In addition, a leak detection technology is described as a way to improve the performance monitoring of the CHPP baghouse, and to ensure its ability to meet environmental requirements.

\subsection{Computerized maintenance management system (CMMS)}

Computerized Maintenance Management Systems (CMMS) are computerized systems used to assist with the effective and efficient management of maintenance activities through the application of computer technology. A CMMS generally includes elements such as a computerized Work Order system, as well as facilities for scheduling Routine Maintenance Tasks, and recording and storing Standard Jobs, Bills of Materials and Applications Parts Lists, equipment and maintenance histories as well as numerous other features. CMMS have many different modules and functions; however, some are absolutely necessary for the proper implementation of any maintenance program.

The Work Order system is used to issue work actions, both preventative and reactive, to technicians. It provides a way to track that work through completion and then to store information gained from the action. That information can in turn be applied to make decisions on equipment disposition, manning requirements, and maintenance system improvements.

Maintenance action scheduling allows the user to define specific time periods between maintenance actions to allow for the automatic scheduling. 
The use of this function requires the implementation of the system database including all equipment and maintenance actions. Inputting all the required data into the CMMS is a labor intensive task that will require one individual to spearhead. Often CMMS companies can provide an on-site consultant to perform that task for an additional charge.

A CMMS with a properly populated database has many advantages. It could allow the work cost estimates to be based on historical data as well as RFQs supplied by vendors. It could also allow failure analysis of equipment by equipment class, parts replaced, and specific manufacturer. Safety and lock out / tag out information can be tied to facility and even specific equipment. Some software packages can tie other electronic data to specific equipment including photos, drawings, procedures, and any other electronic document.

There are many different CMMS packages on the market today. They all have different capabilities and weaknesses. The evaluation of different products for use at the CHPP should include a team including representatives from the CHPP management and maintenance teams. CERL previously authored a study in September 1994 that provided selection criteria for a CMMS (DPSI 2007). These criteria are still valid and are:

- scheduling maintenance actions

- printing work orders

- logging work orders

- inventory parts

- inventory labor

- print maintenance reports.

In addition, the selected CMMS should, ideally, be able to link with the Army's Integrated Facilities System (IFS-M). This would allow data that is entered into the IFS-M to be automatically entered into the CMMS. This would help reduce data entry requirements, by avoiding duplication of effort. Two CMMS software packages are mentioned here only as references. Maximo ${ }^{\circledR}$ is a software package widely used in the power industry. Created and offered by MRO Software, it is a powerful tool that is capable of performing many functions including the ones mentioned above. However it is primarily designed to help manage the maintenance, budget, and purchasing for multiple installations (MRO software 2007). It is an expensive platform, which, while powerful, may not provide a cost effective solution 
at the CHPP. DPSI offers a software package iMaint $®$ that is currently in use at the University of Illinois CHPP (Vavrin 2 June 2006). It is also a powerful tool and offers all the features mentioned in the list above. It appears to have a user friendly interface and intuitive menus (DPSI 2007). Further information on these two products is accessible through URLs:

- Maximo ${ }^{\circledR}$ http://www.mro.com/corporate/mrosolutions/index.php,

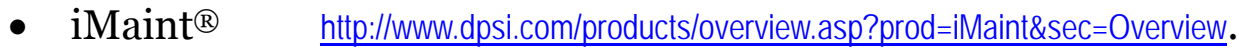

Many products are available that can provide the functions required by the CHPP. It is recommended that as a follow on task a team be developed to investigate the most cost effective solution for use at the CHPP.

The cost of implementing a CMMS will vary depending on the solution chosen. However, costs must be taken into account for the database entry and research that will be required no matter what software is chosen. It takes approximately 1 work-year to populate the database for plants similarly sized to the CHPP. Table 6 lists cost estimate to license, install, train personnel and populate the database. Ongoing costs, which are detailed in the 25-year budget, include license renewals, updates, continuing training and database management. Computer hardware is not considered in this estimate. Once the CMMS software package is chosen then an analysis of the current computer system at the installation needs to be conducted to determine if it is adequate.

Table 6. CMMS implementation costs.

\begin{tabular}{|l|c|l|c|}
\hline \multicolumn{1}{|c|}{ Item } & Price (Each) & \multicolumn{1}{c|}{ Number } & Total \\
\hline Training (On-Site) & $\$ 12,000$ & 8 Technicians & $\$ 12,000$ \\
\hline CMMS Software & $\$ 20,000$ & 1 & $\$ 20,000$ \\
\hline Consultant & $\$ 68,000$ & 1 & $\$ 68,000$ \\
\hline Total & & & $\$ 100,000$ \\
\hline
\end{tabular}

\subsection{Thermal imaging program hardware}

The use of thermal imaging equipment to evaluate the status of equipment is a proven method of determining if there are failures "waiting to happen" in the equipment. Hot bearings, wear points, poor electrical connections, and overloaded motors can all be detected. The cost savings in the use of thermal imaging equipment is the repair of equipment before a catastrophic failure occurs. For example, if a high resistance connection develops 
in the main plant switchgear, due to bus fasteners loosening over time, the results under heavy load conditions could be a major switchgear fire. A thermal imaging camera scan could locate the bad connection and repairs could be made before such a failure occurred. The equipment required is an infrared camera. Many contractors specialize in the use of this equipment and may have better quality equipment than would be fiscally feasible for Fort Wainwright to purchase. An evaluation of local contractors would need to be completed and a cost benefit analysis performed comparing the case of purchasing equipment and training staff to the case of retaining a local contractor to perform the studies. Table 7 lists cost information for the initial investment in equipment and training. Recurring costs are presented in the 25-year maintenance budget and include off site calibration and ongoing training.

Table 7. In-house thermal imaging implementation costs.

\begin{tabular}{|l|l|l|l|}
\hline \multicolumn{1}{|c|}{ Item } & \multicolumn{1}{|c|}{ Price (Each) } & \multicolumn{1}{c|}{ Number } & \multicolumn{1}{c|}{ Total } \\
\hline Training & $\$ 1500$ plus travel & 4 technicians & $\$ 6,000$ plus travel \\
\hline Thermal imaging camera & $\$ 6750$ & 2 & $\$ 13,500$ \\
\hline Total & & & $\$ 19,500$ plus travel \\
\hline
\end{tabular}

\subsection{Vibration analysis program}

All rotating equipment vibrates; vibration monitoring converts this vibration into an electrical signal that can be analyzed to determine if there are any problems. Vibration analysis can have a large return on investment. A study performed on the City of Houston's wastewater treatment department showed a return of $\$ 3.50$ on every dollar invested, not to mention the potential for increased reliability (Levitt 2003). It is likely that the CHPP would receive similar savings by correcting problems before they result in catastrophic failure. For example, repairing bearing problems in motors before a catastrophic failure occurs. The turbine generators currently have a Bentley-Nevada real time vibration monitoring system installed for the bearings. This system inputs directly into the Westinghouse DCS and provides input for alarms. The data is currently not used to figure long-term trends for the equipment and therefore the full benefits of the system are not being captured. Vibration analysis can also help with other pieces of equipment. All rotating equipment can benefit from the use of vibration analysis to predict failures ranging from mechanical misalignment and gear wear to impending gear and bearing failure. Table 8 lists the initial investment in equipment and training for a vibration analysis 
program. The table below provides cost information for the initial investment in equipment and training. Recurring costs are presented in the 25year maintenance budget and include off site calibration and ongoing training.

Table 8. Cost for vibration program implementation.

\begin{tabular}{|l|l|l|l|}
\hline \multicolumn{1}{|c|}{ Item } & \multicolumn{1}{|c|}{ Price (Each) } & \multicolumn{1}{c|}{ Number } & Total \\
\hline Training & $\$ 1,500$ plus travel & 4 technicians & $\$ 6,000$ plus travel \\
\hline Vibration analyzer & $\$ 4,000$ & 2 & $\$ 8,000$ \\
\hline expert software & $\$ 10,000$ & 1 & $\$ 10,000$ \\
\hline Total & & & $\$ 24,000$ plus travel- \\
\hline
\end{tabular}

\subsection{Oil analysis program}

Proper care of the hydraulic and lubricating oil in equipment is necessary for the optimal performance of that equipment. The introduction of microscopic or dissolved contaminants can result in loss of functional life. No equipment is required to be purchased for this program. The oil should be sent to a qualified laboratory that specializes in the types of tests required for the different equipment. The manufacturer's recommended testing should be used in creation of this program. Table 9 lists representative sampling frequencies for various pieces of equipment, based on information obtained from the website for POLARIS Laboratories (2007). Tables 10 and 11, respectively, list oil analysis laboratories and cost estimates for offsite oil analysis.

Table 9. Sampling frequencies for various equipment types.

\begin{tabular}{|c|c|c|}
\hline Equipment Type & $\begin{array}{l}\text { Sampling Interval } \\
\text { Normal / Intermittent Use }\end{array}$ & $\begin{array}{l}\text { Sampling } \\
\text { Location }\end{array}$ \\
\hline Diesel engines & $\begin{array}{l}\text { Quarterly (just prior to oil } \\
\text { drain) }\end{array}$ & $\begin{array}{l}\text { Through dipstick retaining tube or sam- } \\
\text { pling valve installed in filter return }\end{array}$ \\
\hline Hydraulics & $\begin{array}{l}\text { Quarterly (just prior to oil } \\
\text { drain) }\end{array}$ & $\begin{array}{l}\text { Through oil fill port of system reservoir at } \\
\text { mid-level }\end{array}$ \\
\hline Steam turbines & Quarterly & $\begin{array}{l}\text { Through sample valve installed upstream } \\
\text { of the filter on the return line or out of the } \\
\text { system reservoir }\end{array}$ \\
\hline $\begin{array}{l}\text { Gas/air compres- } \\
\text { sors }\end{array}$ & Quarterly & $\begin{array}{l}\text { Through sample valve installed upstream } \\
\text { of the filter on the return line or out of the } \\
\text { system reservoir }\end{array}$ \\
\hline $\begin{array}{l}\text { Gear and bearing } \\
\text { systems }\end{array}$ & Quarterly & $\begin{array}{l}\text { Through petcock valve at exit of each } \\
\text { gear or bearing set or through system } \\
\text { reserve }\end{array}$ \\
\hline
\end{tabular}


Table 10. Oil analysis laboratories.

\begin{tabular}{|l|l|l|l|}
\hline \multicolumn{1}{|c|}{ Company } & \multicolumn{1}{c|}{ Address } & \multicolumn{1}{c|}{ Phone } & \multicolumn{1}{c|}{ Website } \\
\hline $\begin{array}{l}\text { Polaris Labora- } \\
\text { tories, LLC }\end{array}$ & $\begin{array}{l}\text { 7898 Zionsville Road } \\
\text { Indianapolis, IN 46268-2177 }\end{array}$ & $877-808-3750$ & http://www.polarislabs1.com/ \\
\hline Analysts, Inc. & $\begin{array}{l}\text { 2910 Ford Street } \\
\text { Oakland, CA 94601 }\end{array}$ & $800-424-0099$ & $\underline{\text { http://www.analystsinc.com/ }}$ \\
\hline $\begin{array}{l}\text { Herguth Labora- } \\
\text { tories, Inc. }\end{array}$ & $\begin{array}{l}\text { 101 Corporate Place, } \\
\text { Vallejo , CA 94590-6968 }\end{array}$ & 1-888-437-4884 & http://www.herguth.com/ \\
\hline
\end{tabular}

Table 11. Oil analysis cost estimate.

\begin{tabular}{|l|c|c|}
\hline \multicolumn{1}{|c|}{ Equipment } & Number & Annual Cost \\
\hline Steam Turbines & 4 & $\$ 5,700.00$ \\
\hline Diesel Engine & 1 & $\$ 200.00$ \\
\hline Air Compressors & 4 & $\$ 790.00$ \\
\hline Gear Boxes & 12 (estimate) & $\$ 2,360.00$ \\
\hline Hydraulic Units & 12 & $\$ 2,360.00$ \\
\hline Total Annual Cost & & $\$ 11,410.00$ \\
\hline
\end{tabular}

\subsection{Non-destructive evaluation (NDE)}

Many of the previous reports on the condition of the equipment at the Fort Wainwright CHPP recommend an aggressive NDE program to maintain reliability of mechanical systems. In the past severe problems in the piping systems of the CHPP, as evidenced in the report from ZBA Engineering from 1995, have been discovered using NDE techniques. Severe corrosion in the piping to deaerators was discovered by these tests. There are many different technologies available to test pressure bearing elements for problems before they arise. It is beyond the scope of this document to give a complete explanation and evaluation of each individual technology. The technology being recommended is based on operating experience and technologies in use with other operations and maintenance clients. The use of this technology requires suitably trained technicians and the appropriate test equipment. It is recommended that outside contractors be used to perform these tests for large scale evaluations. The cost of equipment and certifications would be prohibitively expensive. Smaller evaluations, such as the tubes in one boiler during an outage can be performed by the maintenance staff. The following sections describe three common types of NDE: Ultrasonics, Eddy Current, and Radiography. 


\subsubsection{Ultrasonic inspection}

Ultrasonic inspection uses sound waves above the range of human hearing to detect cracks and flaws in welds and other metals. Ultrasonic waves will echo from a surface whether that surface is due to a discontinuity or is the opposite surface of the material. The difference in time the echo takes to return determines the distance the flaw is from the probe. A small unit that is in general use in the industry is the KrautKramer CL5 manufactured by GE. It is easy to use and can be used for tubing thickness checks on a small scale during outages. The cost is approximately $\$ 3000$ for the unit and an appropriate probe. An outside contractor should be used to perform testing on a large scale for example a total mapping of boiler tubes. The cost of an outside contractor performing large scale inspections is included in the cost for the boiler maintenance. Table 12 lists cost information for the initial investment in equipment and training for small scale evaluations. Recurring costs are presented in the 25-year maintenance budget and include off site calibration and ongoing training.

Table 12. In-house ultrasonic inspection implementation costs.

\begin{tabular}{|l|l|l|l|}
\hline \multicolumn{1}{|c|}{ Item } & \multicolumn{1}{|c|}{ Price (Each) } & \multicolumn{1}{c|}{ Number } & \multicolumn{1}{c|}{ Total } \\
\hline Training & $\$ 1,500$ plus Travel & 4 Technicians & $\$ 6,000$ plus Travel \\
\hline Ultrasonic Thickness Meter & $\$ 3,000$ & 2 & $\$ 6,000$ \\
\hline Total & & & $\$ 12,000$ plus Travel \\
\hline
\end{tabular}

\subsubsection{Eddy current testing}

A test coil carrying alternating current of various frequencies induces eddy currents into the test material. Eddy currents will flow around discontinuities becoming compressed, delayed, or weakened. The electrical reaction is amplified and recorded on the test equipment. The technique works well with a wide range of ferrous materials, but has very poor response to nonferrous materials. It is recommended that an outside contractor be used for eddy current testing due to the length of time it takes to perform a study and the cost of equipment and training. The cost of an outside contractor performing this test is estimated to be $\$ 12,400$ per year in constant 2006 dollars and is included in the budget. 


\subsubsection{Radiography}

Radiography is the use of radioactive material to produce high energy gamma rays to pass through the test material and strike film. The amount of gamma rays absorbed by the material is directly proportional to the density and amount of material between the source and the film. The more gamma rays that strike the film the darker the film gets. Voids, thinning walls, and other abnormalities will show up as dark spots compared to the continuous material that absorbs more of the gamma rays. This type of testing requires very specific training and materials and is only performed by specialized contractors. This type of inspection should be performed every 10 years on major system piping and components. The cost of these inspections is estimated to be $\$ 18,250$ per year in constant 2006 dollars and is included in the budget items for each system.

\subsection{Environmental concerns}

\subsubsection{Baghouse leak detection and performance measurement improvements}

The CHPP controls particulate matter emissions using a baghouse. The Title $\mathrm{V}$ operating permit for Fort Wainwright requires that baghouse keep PM10 emissions below 0.05 grains per dry standard $\mathrm{cu} f \mathrm{ft}$ averaged over $3 \mathrm{hrs}$. When the operating permit is renewed, a draft compliance assurance monitoring plan (CAM) will be submitted to the Alaska air regulators. The CAM plan will cover performance measurements of the baghouse that will help ensure continuous compliance with the 0.05 grains per dry standard cu ft concentration requirement. The current version of the draft CAM plan recommends that measurements of pressure drop across the baghouse and opacity downstream of the baghouse be used as performance indicators. Of these two measurements, opacity is the more sensitive indicator of deteriorating baghouse performance, but the inherent accuracy limitations and allowable drift can reduce this measurement's usefulness in determining excursions or exceedances of the particulate matter concentration requirement.

The draft CAM plan recommends that opacity readings between 10 and 20 percent be considered an excursion and opacity readings above 20 percent an exceedance. These limits are based on a 1996 source test of the boilers where visual determinations of opacity were made during the course of the 
test. An average of these tests results shows that 10 percent opacity corresponded to the 0.05 grains per dry standard cu ft concentration requirement. More recent source test results are less useful because the baghouse kept the concentrations and opacity readings very low. The recommended opacity ranges are somewhat liberal in that the 1996 source test data suggests that readings of opacity between 10 and 20 percent would indicate concentration values exceeding the permitted concentration standard. The 1996 source test data is also somewhat uncertain because EPA Method 9 was used to obtain opacity readings. Method 9 is based on human observation of plume opacities and is therefore very subjective. The opacity readings are also only recorded in 5 percent increments and therefore a 10 percent reading could indicate actual opacities between 7.5 and 12.5 percent. Because of these uncertainties, it is possible that Alaska air regulators could require lower opacity excursion and exceedance thresholds.

It is fairly well accepted that continuous opacity monitoring systems (COMS) like the one used at the CHPP have uncertainties associated with readings below 10 percent. The EPA has published performance specifications for COMS that cast doubt on COMS ability to accurately measure low opacity values. Performance Specification 1 (PS-1) -Specifications and Test Procedures for Continuous Opacity Monitoring Systems in Stationary Sources found in 40 CFR 60 Appendix B includes the following statements related to opacity measurements less than 10 percent:

The measurement uncertainties associated with COMS data result from several design and performance factors including limitations on the availability of calibration attenuators for opacities less than about 6 percent (3 percent for single-pass instruments), calibration error tolerances, zero and upscale drift tolerances, and allowance for dust compensation that are significant relative to low opacity levels.

The EPA performance specifications for COMS are based on the American Society of Testing and Materials (ASTM) D6216-98 "Standard Practices for Opacity Monitor Manufacturers to Certify Conformance with Design and Performance Specifications." In the August 10, 200 Federal Register entry for the promulgation of amendments to PS-1, the preamble contains the following statements:

The Task Group chairperson for this method indicated in his comments on the supplemental proposal that the calibration error specification of 
\pm 3 percent opacity, the zero and upscale drift specifications of \pm 2 percent opacity, and the PS-1 requirements to adjust monitors when drift exceeds two times the specification (i.e., \pm 4 percent opacity) are inappropriate for monitoring an opacity standard below 10 percent. Special calibration attenuators and calibration techniques, not yet available on a broad basis, are needed for cases where the opacity standard is below 10 percent. He noted that imprecision allowances of this magnitude create excessive uncertainty for establishing compliance with a low opacity limit.

The uncertainty expressed by regulators about low opacity measurements made with COMS also leads to uncertainty over the ability of the CHPP COMS to determine continuous compliance with the PM10 concentration limit.

\subsubsection{Baghouse leak detectors based on triboelectric effect}

A measurement system that was more accurate for low PM10 concentration readings would improve the reliability of determining compliance with the PM10 concentration requirement. Baghouse bag leak detectors based on what is known as the triboelectric effect have been shown to be accurate at these low PM10 concentration readings. When two solids come into contact, an electrical charge is transferred between the two bodies. This charge transfer is known as the triboelectric principle, or contact electrification. As particles in a gas stream collide with a sensor placed in the stream, the charge transfer generates a current that can be measured using triboelectric monitoring equipment. The current signal produced by the triboelectric effect is generally proportional to the particulate mass flow and triboelectric monitoring systems have been shown to detect baseline emissions as low as $0.1 \mathrm{mg} / \mathrm{dscm}$ (0.0000 $5 \mathrm{gr} / \mathrm{dscf}$ ) (USEPA September 1997). Figure 12 shows a typical monitoring schematic for these systems.

Since the triboelectric effect monitors have such high sensitivity, they would have a much greater chance of detecting deterioration of baghouse performance. There are many manufacturers of these monitors and the system could be easily installed at the CHPP. The new bag leak detector would not be a replacement for the COMS since the COMS provides a direct measure of opacity and is needed to show compliance with the 20 percent opacity requirement found in the Title V operating permit. 


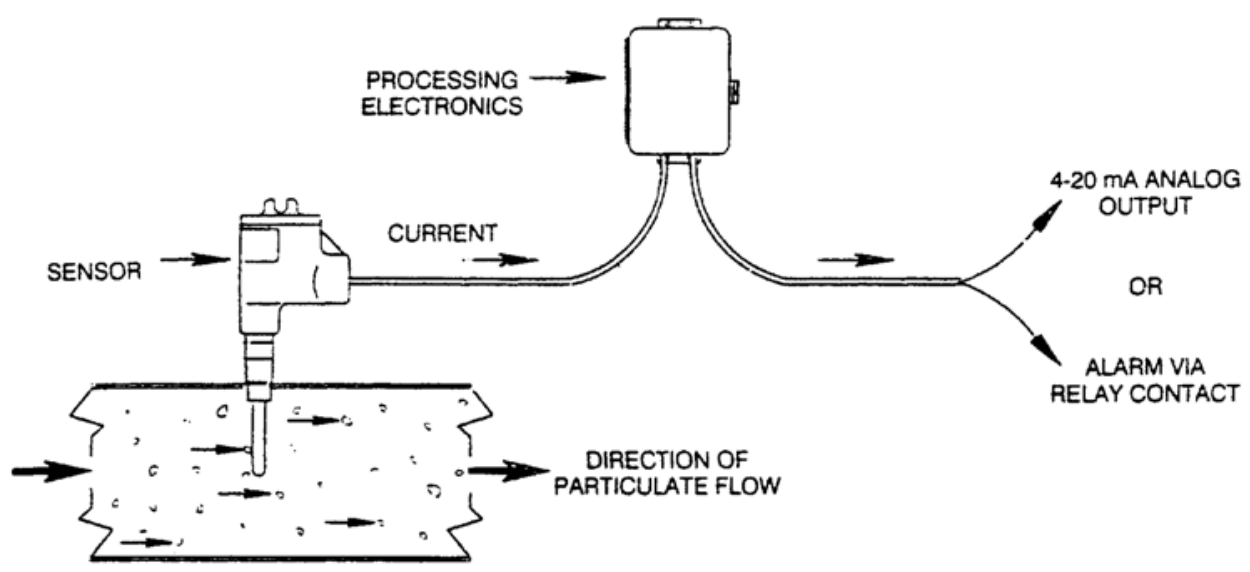

Figure 12. Monitoring system schematic (Source: GEA Power Cooling Systems September 1996).

The installation of this type of bag leak detector would show a good faith effort to maintain continuous compliance with the PM10 concentration requirement and help to maintain the trust that has been built with regulators in the last few years.

\subsection{Prioritization of new technologies}

The technologies described in this chapter, will provide the greatest benefit if used together within the framework of a formalized RCM system. The ideal implementation of these technologies would be a completely parallel system adoption. This is generally not feasible due to time and manpower restraints. Therefore a prioritized implementation of the CMMS or at least initiation of the implementation is recommended. This critical piece of technology is the centerpiece of any maintenance system. It provides scheduling, work tracking and data collection services. Next, the implementation of the Vibration Analysis program will provide the best immediate return on money spent. The results can instantly be put into use to facilitate repairs and prevent impending failures. The Thermal Imaging program will also provide the facility with immediate returns on the investment by discovering problems with the potential of causing fires and severe equipment damage. The Thermal Imaging equipment can also be used to find hot spots to help extinguish smoldering embers should a fire occur. The Oil Analysis program will provide valuable information in the up keep of the plant and is easy to implement. While it may not provide 
immediate benefits, the information gathered will be invaluable for the maintenance of the equipment. The NDE program is listed last because it is to be implemented with the entire maintenance program. This is not to say that NDE is the least important technology. In fact, all of these technologies are needed to maintain the reliability required of the CHPP.

\subsection{Estimated maintenance program costs with recommended technologies}

The estimated budget presented in Table 13 details the cost associated with implementing and supporting the various new technologies at the CHPP. The implementation costs from the previous tables above are reflected in the year 2006 column of Table 13. Subsequent years detail the ongoing costs of supporting the system including: off site calibration of test equipment, continuing training, and replacement cost of equipment at the end of equipment life. The 25-year total for implementation and ongoing support costs come to $\$ 1,164,000$ in constant 2006 dollars. 
Table 13. Estimated maintenance program cost for new technologies (\$2006).

\begin{tabular}{|c|c|c|c|c|c|c|c|c|c|c|c|c|c|}
\hline \multirow[b]{2}{*}{ Year } & \multicolumn{13}{|c|}{ Estimated Maintenance Program Cost, (2006 dollars) } \\
\hline & 2006 & 2007 & 2008 & 2009 & 2010 & 2011 & 2012 & 2013 & 2014 & 2015 & 2016 & 2017 & 2018 \\
\hline \multicolumn{14}{|l|}{ New Technology } \\
\hline Computerized Maintenance Management System & 100,000 & 20,000 & 20,000 & 20,000 & 20,000 & 20,000 & 20,000 & 20,000 & 20,000 & 20,000 & 20,000 & 20,000 & 20,000 \\
\hline Vibration Analysis Systems & 24,000 & 2,000 & 2,000 & 2,000 & 2,000 & 2,000 & 2,000 & 2,000 & 2,000 & 2,000 & 24,000 & 2,000 & 2,000 \\
\hline Thermal Imaging & 20,000 & 2,000 & 2,000 & 2,000 & 2,000 & 2,000 & 2,000 & 2,000 & 2,000 & 2,000 & 20,000 & 2,000 & 2,000 \\
\hline Ultrasonic & 12,000 & 2,000 & 2,000 & 2,000 & 2,000 & 2,000 & 2,000 & 2,000 & 2,000 & 2,000 & 12,000 & 2,000 & 2,000 \\
\hline Oil Analysis & 11,000 & 11,000 & 11,000 & 11,000 & 11,000 & 11,000 & 11,000 & 11,000 & 11,000 & 11,000 & 11,000 & 11,000 & 11,000 \\
\hline Subtotal New Technology & 167,000 & 37,000 & 37,000 & 37,000 & 37,000 & 37,000 & 37,000 & 37,000 & 37,000 & 37,000 & 87,000 & 37,000 & 37,000 \\
\hline
\end{tabular}

Estimated Maintenance Program Cost, (2006 dollars)

\begin{tabular}{|c|c|c|c|c|c|c|c|c|c|c|c|c|c|}
\hline \multirow[b]{2}{*}{ Year } & \multicolumn{13}{|c|}{ Estimated Maintenance Program Cost, (2006 dollars) } \\
\hline & 2019 & 2020 & 2021 & 2022 & 2023 & 2024 & 2025 & 2026 & 2027 & 2028 & 2029 & 2030 & Total \\
\hline \multicolumn{14}{|l|}{ New Technology } \\
\hline Computerized Maintenance Management System & 20,000 & 20,000 & 20,000 & 20,000 & 20,000 & 20,000 & 20,000 & 20,000 & 20,000 & 20,000 & 20,000 & 20,000 & 580,000 \\
\hline Vibration Analysis Systems & 2,000 & 2,000 & 2,000 & 2,000 & 2,000 & 2,000 & 2,000 & 24,000 & 2,000 & 2,000 & 2,000 & 2,000 & 116,000 \\
\hline Thermal Imaging & 2,000 & 2,000 & 2,000 & 2,000 & 2,000 & 2,000 & 2,000 & 20,000 & 2,000 & 2,000 & 2,000 & 2,000 & 103,000 \\
\hline Ultrasonic & 2,000 & 2,000 & 2,000 & 2,000 & 2,000 & 2,000 & 2,000 & 12,000 & 2,000 & 2,000 & 2,000 & 2,000 & 80,000 \\
\hline Oil Analysis & 11,000 & 11,000 & 11,000 & 11,000 & 11,000 & 11,000 & 11,000 & 11,000 & 11,000 & 11,000 & 11,000 & 11,000 & 285,000 \\
\hline Subtotal New Technology & 37,000 & 37,000 & 37,000 & 37,000 & 37,000 & 37,000 & 37,000 & 87,000 & 37,000 & 37,000 & 37,000 & 37,000 & $1,164,000$ \\
\hline
\end{tabular}

Notes: (1) Rounding. The above values might not necessary sum up to the indicated totals due to rounding.

(2) The accuracy of the estimate is + or -30 to 35 percent. 


\section{Overview of PM Budget}

A forecast of the comprehensive budget estimate for the preventative maintenance activities for the CHPP for the period of 2006 through 2030 has been developed. This budget includes the new technologies presented in Chapter 6. The budget is presented in future dollars, which represent the base year estimates listed in Table ES2 (p vi) with escalation factors applied for labor and materials. Material costs have been escalated at an annual rate of 2.09 percent and labor has been escalated at an annual rate of 2.43 percent. These values are consistent with the Department of Energy's Federal Energy Management Program (FEMP) guidelines.

Table 14 lists the factors that have been applied to the baseline 2006 costs that incorporate the annual escalation rates. The factors have been applied to the baseline to estimate the future costs of the preventative maintenance budget.

Table 15 lists the future budgets estimated for the preventative maintenance budget for the CHPP for the period of 2006 through 2030. This table is intended to be used for establishing the future annual budgets for the preventative maintenance program for the CHPP at FWA.
Table 14. Annual factors for future costs.

\begin{tabular}{|r|r|r|}
\hline Year & $\begin{array}{c}\text { Material } \\
\text { Factor }\end{array}$ & $\begin{array}{c}\text { Labor } \\
\text { Factor }\end{array}$ \\
\hline 2006 & 1.0000 & 1.0000 \\
2007 & 1.0209 & 1.0243 \\
2008 & 1.0422 & 1.0492 \\
2009 & 1.0640 & 1.0747 \\
2010 & 1.0863 & 1.1008 \\
2011 & 1.1090 & 1.1276 \\
2012 & 1.1321 & 1.1549 \\
2013 & 1.1558 & 1.1830 \\
2014 & 1.1800 & 1.2118 \\
2015 & 1.2046 & 1.2412 \\
2016 & 1.2298 & 1.2714 \\
2017 & 1.2555 & 1.3023 \\
2018 & 1.2817 & 1.3339 \\
2019 & 1.3085 & 1.3663 \\
2020 & 1.3359 & 1.3995 \\
2021 & 1.3638 & 1.4335 \\
2022 & 1.3923 & 1.4684 \\
2023 & 1.4214 & 1.5040 \\
2024 & 1.4511 & 1.5406 \\
2025 & 1.4814 & 1.5780 \\
2026 & 1.5124 & 1.6164 \\
2027 & 1.5440 & 1.6557 \\
2028 & 1.5763 & 1.6959 \\
2029 & 1.6092 & 1.7371 \\
2030 & 1.6428 & 1.7793 \\
\hline
\end{tabular}


Table 15. Preventative maintenance budget - future costs.

\begin{tabular}{|c|c|c|c|c|c|c|c|c|c|c|c|c|c|}
\hline \multirow[b]{2}{*}{ Year } & \multicolumn{13}{|c|}{ Estimated Maintenance Program Cost, (Future Cost - Estimated to Year of Occuance) } \\
\hline & 2006 & 2007 & 2008 & 2009 & 2010 & 2011 & 2012 & 2013 & 2014 & 2015 & 2016 & 2017 & 2018 \\
\hline Boilers 1 through 6 & $1,500,000$ & $1,530,000$ & $1,570,000$ & $1,600,000$ & $1,640,000$ & $1,470,000$ & $1,540,000$ & $1,620,000$ & $1,700,000$ & $1,780,000$ & $1,870,000$ & $1,960,000$ & $2,060,000$ \\
\hline \multicolumn{14}{|l|}{ Steam Turbine } \\
\hline ST 1 & 200,000 & 102,000 & 130,000 & 137,000 & $1,232,000$ & 292,000 & 160,000 & 168,000 & 177,000 & 186,000 & 196,000 & 206,000 & 217,000 \\
\hline ST 3 & 200,000 & 102,000 & 130,000 & 137,000 & 144,000 & 182,000 & 160,000 & 168,000 & 177,000 & 186,000 & 196,000 & 206,000 & 217,000 \\
\hline ST 4 & 200,000 & 102,000 & 130,000 & $1,202,000$ & 144,000 & 182,000 & 160,000 & 168,000 & 177,000 & 186,000 & 196,000 & 206,000 & 217,000 \\
\hline ST 5 & 200,000 & 102,000 & $1,173,000$ & 137,000 & 144,000 & 152,000 & 160,000 & 168,000 & 177,000 & 186,000 & 196,000 & 206,000 & 217,000 \\
\hline Subtotal Steam Turbine & 800,000 & 409,000 & $1,565,000$ & $1,614,000$ & $1,666,000$ & 608,000 & 640,000 & 673,000 & 708,000 & 745,000 & 784,000 & 825,000 & 869,000 \\
\hline \multicolumn{14}{|l|}{ Balance of Plant } \\
\hline Coal Handling System & 173,000 & 177,000 & 182,000 & 186,000 & 190,000 & 197,000 & 202,000 & 206,000 & 211,000 & 216,000 & 216,000 & 221,000 & 227,000 \\
\hline Ash System (including Baghouse/ID Fan/Env Cont) & 161,000 & 164,000 & 168,000 & 172,000 & 176,000 & 132,000 & 135,000 & 138,000 & 141,000 & 145,000 & 136,000 & 139,000 & 142,000 \\
\hline Steam Piping System & 107,000 & 109,000 & 111,000 & 114,000 & 116,000 & 55,000 & 56,000 & 58,000 & 59,000 & 60,000 & 61,000 & 63,000 & 64,000 \\
\hline Feedwater / Condensate System & 63,000 & 64,000 & 66,000 & 67,000 & 69,000 & 81,000 & 83,000 & 85,000 & 87,000 & 89,000 & 91,000 & 93,000 & 95,000 \\
\hline Cooling System & 187,000 & 191,000 & 195,000 & 200,000 & 204,000 & 50,000 & 51,000 & 52,000 & 53,000 & 54,000 & 38,000 & 39,000 & 39,000 \\
\hline Water Treatment System & 98,000 & 100,000 & 103,000 & 105,000 & 107,000 & 38,000 & 39,000 & 40,000 & 40,000 & 41,000 & 40,000 & 41,000 & 42,000 \\
\hline Instrumentation / Control Systems & 99,000 & 102,000 & 105,000 & 108,000 & 111,000 & 36,000 & 38,000 & 40,000 & 42,000 & 44,000 & 134,000 & 139,000 & 143,000 \\
\hline Eectrical Distribution System & 115,000 & 119,000 & 123,000 & 128,000 & 132,000 & 59,000 & 62,000 & 65,000 & 69,000 & 72,000 & 114,000 & 119,000 & 124,000 \\
\hline Maintenance Shop Equipment, Small Tools, etc. & 15,000 & 16,000 & 17,000 & 17,000 & 18,000 & 19,000 & 20,000 & 21,000 & 22,000 & 24,000 & 25,000 & 26,000 & 27,000 \\
\hline Maintenance Consumables & 40,000 & 42,000 & 44,000 & 47,000 & 49,000 & 51,000 & 54,000 & 57,000 & 60,000 & 63,000 & 66,000 & 70,000 & 73,000 \\
\hline Subtotal Balance of Plant & $1,060,000$ & $1,090,000$ & $1,110,000$ & $1,140,000$ & $1,170,000$ & 720,000 & 740,000 & 760,000 & 780,000 & 810,000 & 920,000 & 950,000 & 980,000 \\
\hline \multicolumn{14}{|l|}{ NewTechnology } \\
\hline Computerized Maintenance Management System & 100,000 & 20,000 & 21,000 & 21,000 & 22,000 & 22,000 & 23,000 & 23,000 & 24,000 & 24,000 & 25,000 & 25,000 & 26,000 \\
\hline Vibration Analysis Systems & 24,000 & 2,000 & 2,000 & 2,000 & 2,000 & 2,000 & 2,000 & 2,000 & 2,000 & 2,000 & 30,000 & 3,000 & 3,000 \\
\hline Thermal Imaging & 20,000 & 2,000 & 2,000 & 2,000 & 2,000 & 2,000 & 2,000 & 2,000 & 2,000 & 2,000 & 24,000 & 3,000 & 3,000 \\
\hline Ultrasonic & 12,000 & 2,000 & 2,000 & 2,000 & 2,000 & 2,000 & 2,000 & 2,000 & 2,000 & 2,000 & 15,000 & 3,000 & 3,000 \\
\hline Oil Analysis & 11,000 & 12,000 & 12,000 & 12,000 & 12,000 & 13,000 & 13,000 & 13,000 & 13,000 & 14,000 & 14,000 & 14,000 & 15,000 \\
\hline Subtotal New Technology & 167,000 & 38,000 & 39,000 & 40,000 & 41,000 & 41,000 & 42,000 & 43,000 & 44,000 & 45,000 & 107,000 & 47,000 & 48,000 \\
\hline Subtotal CHPP Bare Erected Costs & $3,530,000$ & $3,070,000$ & $4,280,000$ & $4,400,000$ & $4,520,000$ & $2,840,000$ & $2,960,000$ & $3,090,000$ & $3,230,000$ & $3,380,000$ & $3,680,000$ & $3,780,000$ & $3,950,000$ \\
\hline Omner's Costs (Engineering @ 5\%) & 176,000 & 153,000 & 214,000 & 220,000 & 226,000 & 142,000 & 148,000 & 155,000 & 162,000 & 169,000 & 184,000 & 189,000 & 198,000 \\
\hline Subtotal Bare Erected Costs and OMner's Costs & $3,700,000$ & $3,220,000$ & $4,500,000$ & $4,620,000$ & $4,740,000$ & $2,980,000$ & $3,110,000$ & $3,250,000$ & $3,400,000$ & $3,550,000$ & $3,870,000$ & $3,970,000$ & $4,150,000$ \\
\hline Project Contingency & 930,000 & 800,000 & $1,120,000$ & $1,150,000$ & $1,190,000$ & 890,000 & 930,000 & 970,000 & $1,020,000$ & $1,060,000$ & $1,350,000$ & $1,390,000$ & $1,450,000$ \\
\hline Total Plant Maintenance Cost (excluding Staffing) & $4,630,000$ & $4,020,000$ & $5,620,000$ & $5,770,000$ & $5,930,000$ & $3,870,000$ & $4,040,000$ & $4,220,000$ & $4,410,000$ & $4,610,000$ & $5,220,000$ & $5,360,000$ & $5,600,000$ \\
\hline Total Plant Labor Cost (Recommended Staffing) & $1,100,000$ & $1,130,000$ & $1,150,000$ & $1,180,000$ & $1,210,000$ & $1,240,000$ & $1,270,000$ & $1,300,000$ & $1,330,000$ & $1,360,000$ & $1,400,000$ & $1,430,000$ & $1,470,000$ \\
\hline Total Plant Cost & $5,730,000$ & $5,150,000$ & $6,780,000$ & $6,950,000$ & $7,140,000$ & $5,110,000$ & $5,310,000$ & $5,520,000$ & $5,750,000$ & $5,980,000$ & $6,620,000$ & $6,790,000$ & $7,070,000$ \\
\hline
\end{tabular}




\begin{tabular}{|c|c|c|c|c|c|c|c|c|c|c|c|c|c|c|}
\hline \multirow[b]{2}{*}{ Year } & \multirow[b]{2}{*}{2018} & \multicolumn{13}{|c|}{ Estimated Maintenance Program Cost, (2006 dollars) } \\
\hline & & 2019 & 2020 & 2021 & 2022 & 2023 & 2024 & 2025 & 2026 & 2027 & 2028 & 2029 & 2030 & Total \\
\hline Boilers 1 through 6 & $2,060,000$ & $2,160,000$ & $2,270,000$ & $2,240,000$ & $2,360,000$ & $2,480,000$ & $2,610,000$ & $2,740,000$ & $2,890,000$ & $3,040,000$ & $3,190,000$ & $3,360,000$ & $3,530,000$ & $54,720,000$ \\
\hline \multicolumn{15}{|l|}{ Steam Turbine } \\
\hline ST 1 & 217,000 & 228,000 & 240,000 & 253,000 & 266,000 & 280,000 & 295,000 & 310,000 & 326,000 & 344,000 & 361,000 & 380,000 & 400,000 & $6,951,000$ \\
\hline ST 3 & 217,000 & 228,000 & 240,000 & 253,000 & 266,000 & 280,000 & 295,000 & 310,000 & 326,000 & 344,000 & 361,000 & 380,000 & 400,000 & $5,863,000$ \\
\hline ST 4 & 217,000 & 228,000 & 240,000 & 253,000 & 266,000 & 280,000 & 295,000 & 310,000 & 326,000 & 344,000 & 361,000 & 380,000 & 400,000 & $6,928,000$ \\
\hline ST5 & 217,000 & 228,000 & 240,000 & 253,000 & 266,000 & 280,000 & 295,000 & 310,000 & 326,000 & 344,000 & 361,000 & 380,000 & 400,000 & $6,906,000$ \\
\hline Subtotal Steam Turbine & 869,000 & 914,000 & 962,000 & $1,012,000$ & $1,065,000$ & $1,121,000$ & $1,179,000$ & $1,241,000$ & $1,306,000$ & $1,374,000$ & $1,446,000$ & $1,521,000$ & $1,601,000$ & $26,648,000$ \\
\hline \multicolumn{15}{|l|}{ Balance of Plant } \\
\hline Coal Handling System & 227,000 & 232,000 & 237,000 & 248,000 & 254,000 & 259,000 & 265,000 & 272,000 & 278,000 & 284,000 & 291,000 & 298,000 & 305,000 & $5,827,000$ \\
\hline Ash System (including Baghouse/ID Fan/Env Cont) & 142,000 & 145,000 & 149,000 & 152,000 & 156,000 & 159,000 & 163,000 & 167,000 & 170,000 & 174,000 & 178,000 & 182,000 & 187,000 & $3,933,000$ \\
\hline Steam Piping System & 64,000 & 66,000 & 67,000 & 64,000 & 65,000 & 67,000 & 68,000 & 70,000 & 74,000 & 76,000 & 77,000 & 79,000 & 81,000 & $1,885,000$ \\
\hline Feedwater / Condensate System & 95,000 & 97,000 & 99,000 & 68,000 & 70,000 & 71,000 & 73,000 & 74,000 & 120,000 & 122,000 & 125,000 & 128,000 & 131,000 & $2,209,000$ \\
\hline Cooling System & 39,000 & 40,000 & 41,000 & 63,000 & 64,000 & 66,000 & 67,000 & 69,000 & 103,000 & 105,000 & 107,000 & 110,000 & 112,000 & $2,301,000$ \\
\hline Water Treatment System & 42,000 & 43,000 & 43,000 & 29,000 & 29,000 & 30,000 & 30,000 & 31,000 & 68,000 & 70,000 & 71,000 & 73,000 & 75,000 & $1,426,000$ \\
\hline Instrumentation / Control Systems & 143,000 & 148,000 & 153,000 & 60,000 & 63,000 & 66,000 & 70,000 & 73,000 & 186,000 & 192,000 & 199,000 & 206,000 & 213,000 & $2,768,000$ \\
\hline Eectrical Distribution System & 124,000 & 129,000 & 135,000 & 98,000 & 103,000 & 108,000 & 113,000 & 119,000 & 125,000 & 132,000 & 139,000 & 146,000 & 153,000 & $2,801,000$ \\
\hline Maintenance Shop Equipment, Small Tools, etc. & 27,000 & 29,000 & 30,000 & 32,000 & 34,000 & 35,000 & 37,000 & 39,000 & 41,000 & 43,000 & 45,000 & 48,000 & 50,000 & 731,000 \\
\hline Maintenance Consumables & 73,000 & 77,000 & 81,000 & 85,000 & 89,000 & 94,000 & 99,000 & 104,000 & 109,000 & 115,000 & 121,000 & 127,000 & 134,000 & $1,950,000$ \\
\hline Subtotal Balance of Plant & 980,000 & $1,010,000$ & $1,040,000$ & 900,000 & 930,000 & 960,000 & 990,000 & $1,020,000$ & $1,270,000$ & $1,310,000$ & $1,350,000$ & $1,400,000$ & $1,440,000$ & $25,830,000$ \\
\hline \multicolumn{15}{|l|}{ New Technology } \\
\hline Computerized Maintenance Management System & 26,000 & 26,000 & 27,000 & 27,000 & 28,000 & 28,000 & 29,000 & 30,000 & 30,000 & 31,000 & 32,000 & 32,000 & 33,000 & 728,000 \\
\hline Vibration Analysis Systems & 3,000 & 3,000 & 3,000 & 3,000 & 3,000 & 3,000 & 3,000 & 3,000 & 36,000 & 3,000 & 3,000 & 3,000 & 3,000 & 147,000 \\
\hline Thermal Imaging & 3,000 & 3,000 & 3,000 & 3,000 & 3,000 & 3,000 & 3,000 & 3,000 & 29,000 & 3,000 & 3,000 & 3,000 & 3,000 & 130,000 \\
\hline Ultrasonic & 3,000 & 3,000 & 3,000 & 3,000 & 3,000 & 3,000 & 3,000 & 3,000 & 18,000 & 3,000 & 3,000 & 3,000 & 3,000 & 102,000 \\
\hline Oil Analysis & 15,000 & 15,000 & 15,000 & 16,000 & 16,000 & 16,000 & 17,000 & 17,000 & 17,000 & 18,000 & 18,000 & 18,000 & 19,000 & 370,000 \\
\hline Subtotal New Technology & 48,000 & 49,000 & 50,000 & 51,000 & 52,000 & 53,000 & 54,000 & 55,000 & 131,000 & 58,000 & 59,000 & 60,000 & 61,000 & $1,477,000$ \\
\hline Subtotal CFPPBare Erected Costs & $3,950,000$ & 4,130,000 & $4, \mathbf{4 3 2 0 , 0 0 0}$ & $\begin{array}{l}\mathbf{4} 200,000 \\
\end{array}$ & $4,4,400,000$ & $4,4,610,000$ & $4,4,830,000$ & $\overline{5,060,000}$ & $\overline{5,600,000}$ & $\overline{5,780,000}$ & 6,050,000 & 6,340,000 & $6,6,640,000$ & $108,670,000$ \\
\hline Ouner's Costs (Engineering @ 5\%) & 198,000 & 207,000 & 216,000 & 210,000 & 220,000 & 230,000 & 241,000 & 253,000 & 280,000 & 289,000 & 303,000 & 317,000 & 332,000 & $5,434,000$ \\
\hline Subtotal Bare Erected Costs and Onner's Costs & $4,150,000$ & $4,340,000$ & $4,530,000$ & $4,410,000$ & $4,620,000$ & $4,840,000$ & $\overline{5,070,000}$ & $5,310,000$ & $5,880,000$ & $6,070,000$ & $6,360,000$ & $6,650,000$ & $6,970,000$ & $1114,110,000$ \\
\hline Project Contingency & $1,450,000$ & $1,520,000$ & $1,590,000$ & $1,770,000$ & $1,850,000$ & $1,940,000$ & $2,030,000$ & $2,120,000$ & $2,350,000$ & $2,430,000$ & $2,540,000$ & $2,660,000$ & $2,790,000$ & $39,850,000$ \\
\hline Total Plant Maintenance Cost (excluding Staffing) & $5,600,000$ & $5,860,000$ & $6,120,000$ & $6,180,000$ & $6,470,000$ & $6,780,000$ & $7,100,000$ & $7,440,000$ & $8,230,000$ & $8,500,000$ & $8,900,000$ & $9,320,000$ & $9,760,000$ & $153,960,000$ \\
\hline Total Plant Labor Cost (Recommended Staffing) & $1,470,000$ & $1,500,000$ & $1,540,000$ & $1,580,000$ & $1,610,000$ & $1,650,000$ & $1,690,000$ & $1,730,000$ & $1,780,000$ & $1,820,000$ & $1,860,000$ & $1,910,000$ & $1,960,000$ & $37,200,000$ \\
\hline Total Plant Cost & $7,070,000$ & $7,360,000$ & $7,660,000$ & $7,750,000$ & $8,080,000$ & $8,430,000$ & $8,790,000$ & $9,170,000$ & $10,010,000$ & $10,320,000$ & $10,760,000$ & $11,230,000$ & $11,710,000$ & $191,160,000$ \\
\hline
\end{tabular}




\section{Results and Discussion}

\subsection{Reliability centered maintenance (RCM)}

A Reliability Centered Maintenance (RCM) program contains the optimum mix of reactive, time-based, condition-based, and proactive maintenance practices. These principal maintenance strategies, rather than being applied independently, are integrated to take advantage of their respective strengths to maximize facility and equipment reliability while minimizing life-cycle costs. RCM is a system based approach that takes into account the overall function of the system rather than the individual parts of that system (Smith and Hinchcliffe 2004). The primary RCM principles emphasize a system that is:

- Function Oriented. RCM seeks to preserve system or equipment function.

- System Focused. RCM is more concerned with maintaining system function than with individual component function.

- Reliability Centered. RCM is not overly concerned with simple failure rate; it seeks to know the probability that failure will occur in each given operating age bracket of the system. The curves in Figure 13 represent seven different models of failure.

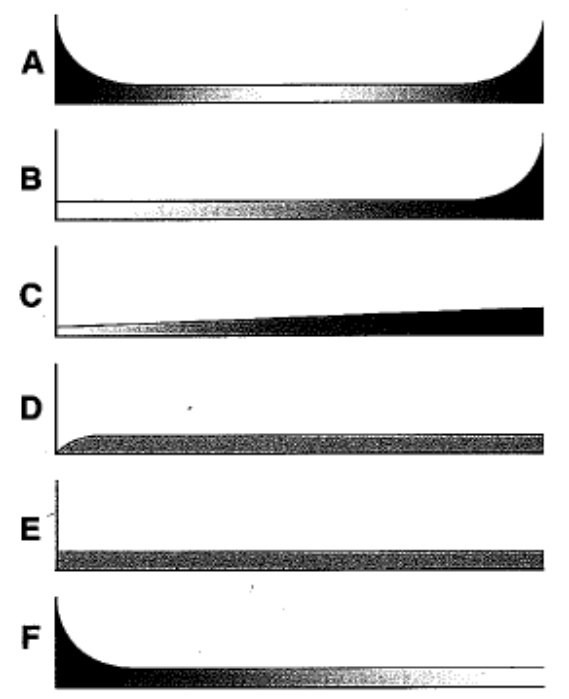

Figure 13. Lifetime failure curves. 
Curve A shows the standard "bathtub" curve that represents an initial high failure rate (also known as infant mortality) followed by a constant failure rate. As the component ages and nears the end of its design life the failure rate increases again.

Curve B represents a constant initial failure rate and as the component ages and nears the end of its design life the rate increases.

Curve $\mathrm{C}$ shows a low initial failure rate followed by a slow linear increase in failure rate as the component ages.

Curve D shows a rapidly increasing failure rate during initial operations to a steady state failure rate during the rest of the design life of the component.

Curve E shows a steady failure rate throughout the life of the component.

Curve F represents a high infant mortality rapidly decreasing failure rate to a steady state rate over the rest of the component's life (Moubray 1997).

These many different modes of failure have led to the concept of mixing different maintenance philosophies and blending their strengths to minimize the likelihood of all the different failure modes cost effectively in a system that:

- Acknowledges Design Limitations. The RCM objective is to maintain the reliability of the equipment, recognizing that changes in reliability are a function of design as well as maintenance. Maintenance can, at best, only achieve and maintain the level of reliability that was provided for by design. However, RCM recognizes that maintenance feedback can improve on the original design. This is accomplished by reviewing maintenance and determining if changing materials, reconfiguration, or any other engineering changes can improve reliability.

- Requires That Maintenance Tasks Be Applicable. The tasks must address the failure mode and consider the failure mode characteristics.

- Requires That Maintenance Tasks Be Effective. The tasks must reduce the probability of failure and be cost-effective. 
- Acknowledges Four Types of Maintenance Tasks: (1) reactive, (2) time-directed or preventive maintenance, (3) condition-directed or predictive maintenance, and (4) failure finding or functional testing. Time-directed tasks are scheduled when appropriate. Predictive tasks are performed to determine when conditions are appropriate to perform a particular task. For example, ultrasonic thickness measurement of boiler tubes shows when a tube needs to be plugged or a retubing is necessary. Failure-finding tasks detect hidden functions that are in danger of causing premature failure such as the failure of a low lube oil pressure trip sensor.

- Is a "Living System." RCM gathers data from the results achieved and feeds this data back to improve design and future maintenance. This feedback is an important part of the Proactive Maintenance element of the RCM program (MRO software 2007).

The implementation of a new RCM system will require the addition of new technologies, equipment, and skills to the existing plant. The addition of some kind of Computerized Maintenance Management System (CMMS) is paramount to the success of any maintenance program and doubly so for an RCM type program. The CMMS is the heart of any system with its ability to store, retrieve, and export vast amounts of data. It will allow the seamless tracking of reactive maintenance actions, the scheduling of time based items, and data storage for the condition based items (Bowman and Moshage September 1994). The data can be analyzed using any number of different tools to determine the statistical probability of failure for different pieces of equipment.

The installation of a secure plant wide computer network would greatly improve the efficiency of any added CMMS system. The adoption of other new technologies including Vibration Analysis, Thermal Imaging, and a real time data collection system to collect data directly from the Distributed Control System (DCS) will be required to perform the condition based portions of the program. These technologies will require the purchase of required diagnostic equipment and supporting computer software. Training of technicians and management in the use of this equipment will be critical to the success of the program. The implementation of the system will be labor intensive and require the commitment from management for the program to be successful. 
During the implementation of the system, the plant personnel will still be repairing equipment that has been suffering from a lack of a maintenance program. This leads to an increased cost initially to implement the program. The cost of repairs will remain high until all of the major repairs have been made. This situation results in the misconception that it actually costs more money to operate with a maintenance program in place then it did when the plant was operating on a purely reactive basis. Costs will eventually come down, but reliability is the major benefit for the facility. RCM type systems have resulted in a 50 percent or more decrease in the breakdown rate of equipment (Smith and Hinchcliffe 2004). This does not necessarily translate directly into added reliability of the equipment. It means that maintenance issues are handled during scheduled outages that can be controlled by the CHPP. This can cascade into cost savings on acquiring needed spare parts or obtaining contractor services over a longer period of time instead of placing rush orders, which often have a price premium attached to them.

\subsection{Estimated implementation schedule}

The implementation plan will be discussed first in terms of items that are common to the whole plant and then will be discussed by items that are specific to each major system.

\subsubsection{General implementation}

The implementation of any new maintenance system is a large and complex task that requires careful planning and forethought. The implementation must be broken down into carefully considered and manageable steps. Infrastructure (i.e., new equipment), software, and tools need to be acquired first.

The easiest portion of the system to implement will be the "reactive maintenance" portion, since reactive maintenance forms the basis for current CHHP maintenance. The installation of the CMMS will allow the creation and tracking of work orders for reactive maintenance actions that will allow for better management and tracking of technician's time, equipment downtime, the root cause of the problem, and reporting. Next, each piece of equipment will have to have its boundaries set, an evaluation performed, and a decision made as to what type of maintenance action will be performed for that piece of equipment. The types of failures and the re- 
sults of each failure mode will be formulated for each piece of equipment. The results of this assessment and a logic tree (Figure 14) will be used to determine the type of maintenance action that will be used.

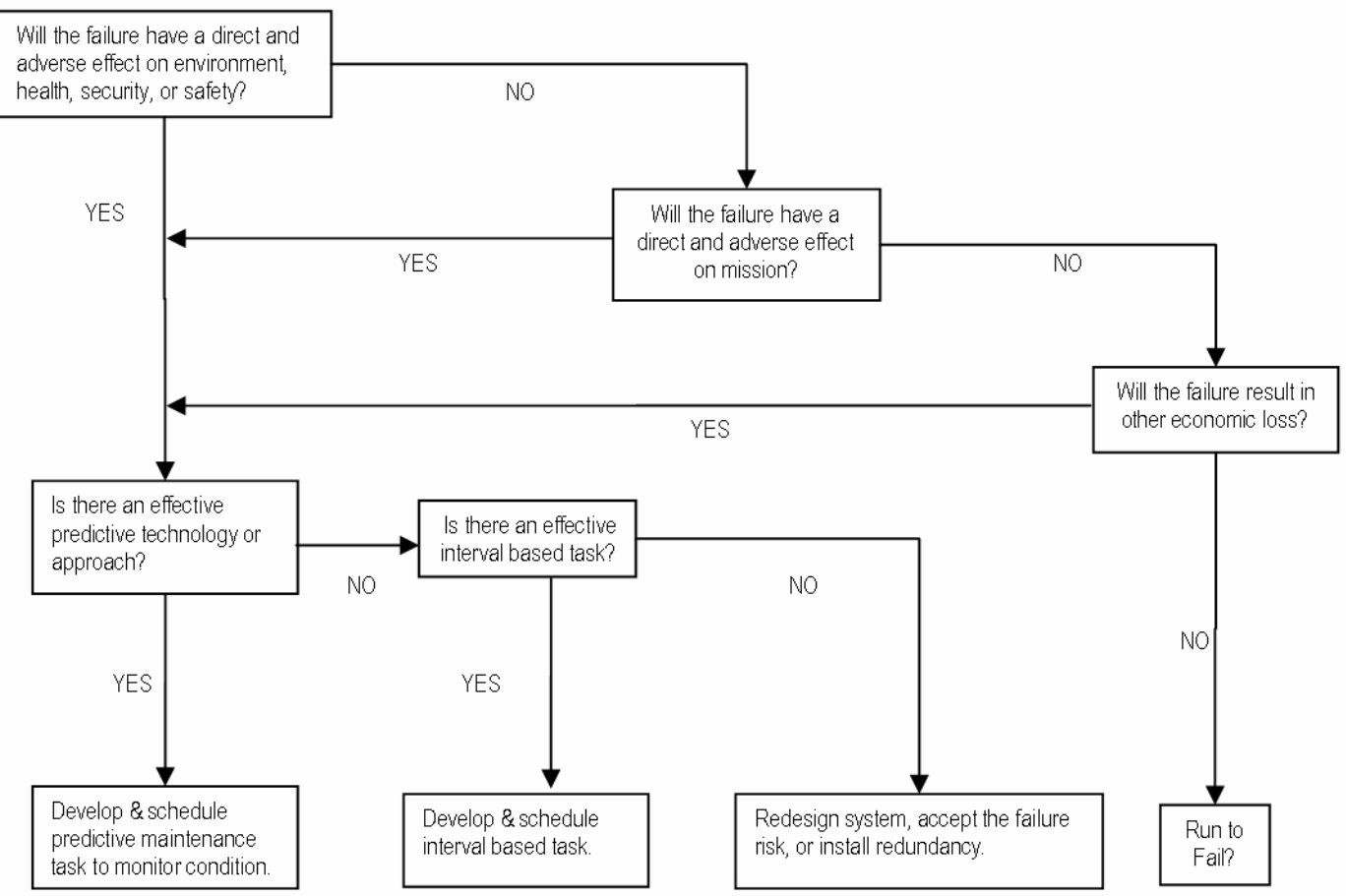

Figure 14. RCM logic tree.

The maintenance actions recommended below are not intended to be an exhaustive list, but to be used as a guide. These recommendations are based on past operating experience, judgment, and manufacturer's recommendations for similar systems.

Table 16 presents actions that are relevant to all the plant systems and are easier to breakout separately then include in the individual system tables. 
Table 16. Plant wide maintenance actions.

\begin{tabular}{|c|c|c|c|}
\hline Maintenance action & Periodicity & Type* & Notes \\
\hline $\begin{array}{l}\text { Radiographic Inspec- } \\
\text { tion }\end{array}$ & 10 yrs & $\mathrm{P}$ & $\begin{array}{l}\text { Perform a radiographic inspection of all major } \\
\text { plant systems }\end{array}$ \\
\hline All pumps & Annually & $\mathrm{P}$ & $\begin{array}{l}\text { All pumps will be inspected for impellor wear, } \\
\text { casing wear, shaft eccentricity, correct coupling } \\
\text { and pump performance }\end{array}$ \\
\hline Oil Sample Analysis & $\begin{array}{l}\text { Semi- } \\
\text { Annually }\end{array}$ & $\mathrm{P}$ & $\begin{array}{l}\text { All equipment that uses oil in any way will have } \\
\text { a sample taken and analyzed to ensure compli- } \\
\text { ance with manufacturer's recommendations }\end{array}$ \\
\hline $\begin{array}{l}\text { All Motors, Pumps, } \\
\text { Conveyors and Fans }\end{array}$ & Monthly & $\mathrm{T}$ & Lubricate all bearings \\
\hline $\begin{array}{l}\text { Vibratory Monitoring of } \\
\text { all rotating equipment }\end{array}$ & Monthly & $\mathrm{P}$ & $\begin{array}{l}\text { The plant will be broken down into six zones and } \\
\text { each zone will be surveyed once a month. This } \\
\text { is so the entire plant will be surveyed every six } \\
\text { months }\end{array}$ \\
\hline $\begin{array}{l}\text { Thermal Imaging of all } \\
\text { Plant Equipment }\end{array}$ & Monthly & $\mathrm{P}$ & $\begin{array}{l}\text { The plant will be broken down into six zones and } \\
\text { each zone will be imaged once a month. This is } \\
\text { so the entire plant will be imaged every six } \\
\text { months }\end{array}$ \\
\hline $\begin{array}{l}\text { All Electrical Boxes, } \\
\text { Control Cabinets, and } \\
\text { Switchgear Clean and } \\
\text { Inspect }\end{array}$ & Monthly & $\mathrm{T}$ & $\begin{array}{l}\text { The plant will be broken down into six zones and } \\
\text { all electrical equipment in each zone will be } \\
\text { cleaned and inspected each month. This is so } \\
\text { all equipment will be cleaned and inspected } \\
\text { every six months. }\end{array}$ \\
\hline $\begin{array}{l}\text { Piping and Weld In- } \\
\text { spection }\end{array}$ & Monthly & $P$ & $\begin{array}{l}\text { The plant will be broken down into } 12 \text { zones } \\
\text { and all process piping, welds and fittings in one } \\
\text { zone will be inspected each month }\end{array}$ \\
\hline Valve Exercising & Monthly & $\mathrm{T}$ & $\begin{array}{l}\text { The plant will be broken down into six zones and } \\
\text { all valves in one zone will be cycled monthly }\end{array}$ \\
\hline $\begin{array}{l}\text { Motor, Generator, and } \\
\text { Distribution Insulation } \\
\text { Resistance Checks }\end{array}$ & Monthly & $\mathrm{P}$ & $\begin{array}{l}\text { The plant will be broken down into six zones and } \\
\text { all motors in one zone will be tested each } \\
\text { month so that all motors will be tested every six } \\
\text { months }\end{array}$ \\
\hline $\begin{array}{l}\text { Belt Driven Equipment } \\
\text { Checks }\end{array}$ & Monthly & $\mathrm{T}$ & $\begin{array}{l}\text { The plant will be broken down into six zones and } \\
\text { all belt driven equipment in a zone will be } \\
\text { checked each month so that all equipment will } \\
\text { be checked every six months }\end{array}$ \\
\hline $\begin{array}{l}\text { Turbine Lubricating Oil } \\
\text { Sample Analysis }\end{array}$ & Monthly & $\mathrm{P}$ & $\begin{array}{l}\text { All turbine lubricating oil will be sampled } \\
\text { monthly and changed when required by sample } \\
\text { analysis }\end{array}$ \\
\hline $\begin{array}{l}\text { Air Lubricator and Filter } \\
\text { Inspection }\end{array}$ & Monthly & $\mathrm{T}$ & Drain and fill all Air Lubricators and filters \\
\hline $\begin{array}{l}\text { Clean and Inspect Suc- } \\
\text { tion Strainers }\end{array}$ & Monthly & $T$ & $\begin{array}{l}\text { Clean and inspect the suction strainer of all } \\
\text { pumps }\end{array}$ \\
\hline
\end{tabular}




\subsubsection{Schedule by system}

This section presents information on the boiler, steam turbines, and the following major plant systems:

- feedwater system

- condensate system

- steam system

- coal handling system

- ash handling system

- cooling system

- water treatment system

- electrical system

- instrument and controls system.

The major maintenance actions and recommended periodic maintenance requirements will be presented in this section. The condition based requirements that may be needed will be addressed, but final determination of maintenance requirements will be performed with the equipment evaluations during system implementation.

\subsubsection{Boilers}

Table 17 details the annual operating hours for the 3-year period (2002 to 2004) for all six operating boilers. The hours of all boilers are within 20 percent of the average of all six. It is therefore assumed that all boilers have been operated a similar number of hours over their operating lives thus far and are in a similar state of repair.

Table 17. Three-year boiler operating hours.

\begin{tabular}{|l|r|c|r|r|c|c|c|}
\hline Year & Boiler \#3 & Boiler \#4 & Boiler \#5 & \multicolumn{1}{c|}{ Boiler \#6 } & Boiler \#7 & Boiler \#8 & Average \\
\hline 2002 & 6326.9 & 7369.05 & 5664.7 & 3098.93 & 4053.87 & 7020.75 & 5589.033 \\
\hline 2003 & 6895.7 & 3081.8 & 6368.9 & 6407.8 & 7245.7 & 2630.4 & 5438.4 \\
\hline 2004 & 6757.1 & 5955.6 & 4658.1 & 4677.6 & 4214.0 & 3824.7 & 5014.5 \\
\hline Total & $19,979.6$ & $16,406.5$ & $16,691.7$ & $14,184.3$ & $15,513.6$ & $13,475.9$ & $16,041.9$ \\
\hline
\end{tabular}

The maintenance actions recommended below are not intended to be an exhaustive list, but to be used as a guide. These recommendations are based on past operating experience, judgment, and manufacturer's recommendations for similar systems. Table 18 lists the recommended boiler maintenance schedule. 
Table 18. Boiler recommended maintenance actions.

\begin{tabular}{|c|c|c|c|}
\hline Maintenance action & Periodicity & Type* & Notes \\
\hline Safety relief valves test & Annually & $\mathrm{F}$ & Test pressure at which valve lifts \\
\hline $\begin{array}{l}\text { Boiler inspection by regula- } \\
\text { tory agency }\end{array}$ & Annually & $\mathrm{T}$ & $\begin{array}{l}\text { Inspection by the required regulatory } \\
\text { agency to ASME standards }\end{array}$ \\
\hline Boiler inspection & $\begin{array}{l}\text { Semi- } \\
\text { Annually }\end{array}$ & $\mathrm{T}$ & $\begin{array}{l}\text { Check fastener tightness, boiler supports, } \\
\text { setting for cracks, baffles, blowdown pip- } \\
\text { ing, boiler drain valves }\end{array}$ \\
\hline $\begin{array}{l}\text { Water wall tubes and head- } \\
\text { ers ultrasonic inspection }\end{array}$ & $\begin{array}{l}\text { Semi- } \\
\text { Annually }\end{array}$ & $\mathrm{P}$ & $\begin{array}{l}\text { Perform on one boiler semi-annually on a } \\
\text { rotating basis. }\end{array}$ \\
\hline $\begin{array}{l}\text { Superheater tubes and } \\
\text { headers ultrasonic inspec- } \\
\text { tion }\end{array}$ & $\begin{array}{l}\text { Semi- } \\
\text { Annually }\end{array}$ & $\mathrm{P}$ & $\begin{array}{l}\text { Perform on one boiler semi-annually on a } \\
\text { rotating basis. }\end{array}$ \\
\hline $\begin{array}{l}\text { Economizer tubes and head- } \\
\text { ers ultrasonic inspection }\end{array}$ & $\begin{array}{l}\text { Semi- } \\
\text { Annually }\end{array}$ & $\mathrm{P}$ & $\begin{array}{l}\text { Perform on one boiler semi-annually on a } \\
\text { rotating basis. }\end{array}$ \\
\hline Boiler refractory inspection & $\begin{array}{l}\text { Semi- } \\
\text { Annually }\end{array}$ & $\mathrm{T}$ & $\begin{array}{l}\text { Perform on one boiler semi-annually on a } \\
\text { rotating basis. }\end{array}$ \\
\hline $\begin{array}{l}\text { Steam and mud drums in- } \\
\text { spection and nde }\end{array}$ & $\begin{array}{l}\text { Semi- } \\
\text { Annually }\end{array}$ & $P$ & $\begin{array}{l}\text { Perform on one boiler semi-annually on a } \\
\text { rotating basis. }\end{array}$ \\
\hline Fd fans inspection & $\begin{array}{l}\text { Semi- Annu- } \\
\text { ally }\end{array}$ & $\mathrm{T}$ & $\begin{array}{l}\text { Perform on all Fans Visual Inspection of } \\
\text { expansion joints, casing and blades. En- } \\
\text { sure rotates freely. }\end{array}$ \\
\hline Boiler grate drives lubrication & $\begin{array}{l}\text { Semi- Annu- } \\
\text { ally }\end{array}$ & $\mathrm{T}$ & $\begin{array}{l}\text { Oil chains and inspect for broken or de- } \\
\text { formed links }\end{array}$ \\
\hline Casing & $\begin{array}{l}\text { Semi- } \\
\text { Annually }\end{array}$ & $\mathrm{T}$ & Inspect, repair as required \\
\hline Boiler grate drives inspection & Monthly & $\mathrm{T}$ & Inspect seals, rails, bearings, and VFDs \\
\hline $\begin{array}{l}\text { Boiler coal spreader stoker } \\
\text { inspection }\end{array}$ & Monthly & $\mathrm{T}$ & $\begin{array}{l}\text { Inspect all mechanicals including under- } \\
\text { throw feeder }\end{array}$ \\
\hline Sootblower inspection & Monthly & $\mathrm{T}$ & Inspect all mechanicals including piping \\
\hline Overfire air fans & Monthly & $\mathrm{T}$ & Inspect all mechanicals \\
\hline $\begin{array}{l}\text { Safety relief valves manual } \\
\text { lift }\end{array}$ & Monthly & $\mathrm{T}$ & $\begin{array}{l}\text { Use mechanical override device to open } \\
\text { valve and blow material clear of seat }\end{array}$ \\
\hline $\begin{array}{l}\text { Water whistle test and in- } \\
\text { spect }\end{array}$ & Monthly & $\mathrm{F}$ & Inspect and Test repair as required \\
\hline
\end{tabular}

\subsubsection{Steam turbines}

The steam turbines will require periodic maintenance to maintain efficiency and reliability. Other maintenance will be required on the turbine support systems including oil analysis on the lubricating and control oil, lube oil pumps, governor equipment, etc. The steam turbines will require an overhaul to bring their material condition to the highest level. After these overhauls are performed the regular maintenance schedule will en- 
sure these overhaul items are conducted only when they are required to maintain the turbines. This will result in a levelized budget since overhaul items are spread out over several maintenance cycles. It is recommended that they receive overhauls on the following schedule: Steam Turbine \# 5 in 2008, Steam Turbine \# 4 2009, and Steam Turbine \# 1 in 2010. Steam Turbine \# 3 was just overhauled in 2005.

It is assumed that, during their life time, each turbine (except STG-1) has been operated on average a similar number of hours each year and are in similar condition. ${ }^{*}$ STG-1 is assumed to be in operation November through April each year.

The maintenance actions recommended below are not intended to be an exhaustive list, but to be used as a guide. These recommendations are based on past operating experience, judgment, and manufacturer's recommendations for similar systems. Table 19 lists the recommended steam turbine maintenance schedule.

Table 19. Recommended steam turbine maintenance.

\begin{tabular}{|c|c|c|c|}
\hline Maintenance action & Periodicity & Type* & Notes \\
\hline Borescope steam flow path & Annually & $\mathrm{P}$ & $\begin{array}{l}\text { Inspect entire steam flow path from } \\
\text { turbine stop valve to turbine exit }\end{array}$ \\
\hline Lube oil pump capacity test & Annually & $\mathrm{F}$ & $\begin{array}{l}\text { Ensure Lube Oil pump is pumping to } \\
\text { specs }\end{array}$ \\
\hline $\begin{array}{l}\text { Inspect all control, admis- } \\
\text { sion/extraction, and non-return } \\
\text { valves }\end{array}$ & Annually & $\mathrm{T}$ & $\begin{array}{l}\text { Conduct functional tests, inspect } \\
\text { and repair as required }\end{array}$ \\
\hline Steam seal system inspection & Annually & $\mathrm{T}$ & $\begin{array}{l}\text { Inspect and check tolerances repair } \\
\text { as required }\end{array}$ \\
\hline Governor inspection & Annually & $\mathrm{T}$ & $\begin{array}{l}\text { Inspect all aspects of governor and } \\
\text { test overspeed trip }\end{array}$ \\
\hline Generator polarization index & Annually & $\mathrm{T}$ & $\begin{array}{l}\text { Measure Polarization of generator } \\
\text { windings }\end{array}$ \\
\hline Generator inspection & Annually & $\mathrm{T}$ & Inspection of all mechanicals \\
\hline Change lube oil filters & Monthly & $\mathrm{T}$ & Change lube oil filters \\
\hline External inspection & Monthly & $\mathrm{T}$ & $\begin{array}{l}\text { Visual Inspection of the exterior of } \\
\text { TG and all auxiliary equipment }\end{array}$ \\
\hline
\end{tabular}

* An attempt was made to use operating data from the DCS logger software. However, the data was believed to be unreliable. 


\subsubsection{Feedwater}

Periodic and condition based maintenance actions will be required to be performed on the feedwater pumps. These items will include vibration analysis to determine bearing health, oil analysis on lubricating oil, replacement of seals and wear rings, periodic disassembly and inspection, turbine overhaul, etc.

The maintenance actions recommended below are not intended to be an exhaustive list, but to be used as a guide. These recommendations are based on past operating experience, judgment, and manufacturer's recommendations for similar systems. Table 20 lists the recommended feedwater system maintenance schedule.

Table 20. Recommended feedwater system maintenance.

\begin{tabular}{|c|c|c|c|}
\hline Maintenance action & Periodicity & Type* & Notes \\
\hline $\begin{array}{l}\text { Measure wear sur- } \\
\text { faces }\end{array}$ & Annually & $\mathrm{T}$ & $\begin{array}{l}\text { Inspect and check tolerances of OD of the inte- } \\
\text { gral impeller wear surfaces and the ID of the cas- } \\
\text { ing rings repair as required }\end{array}$ \\
\hline $\begin{array}{l}\text { Measure OD of inter- } \\
\text { stage sleeves }\end{array}$ & Annually & $\mathrm{T}$ & Inspect and check tolerances repair as required \\
\hline $\begin{array}{l}\text { Examine impeller } \\
\text { passages for cracks, } \\
\text { dents, gauges }\end{array}$ & Annually & $\mathrm{T}$ & Inspect and check tolerances repair as required \\
\hline $\begin{array}{l}\text { Inspect shaft sleeves } \\
\text { for excessive wear }\end{array}$ & Annually & $\mathrm{T}$ & Inspect and check tolerances repair as required \\
\hline $\begin{array}{l}\text { De-aerator inspection } \\
\text { and NDE }\end{array}$ & Annually & $\mathrm{P}$ & $\begin{array}{l}\text { Open and Inspect De-Aerators perform NDE on } \\
\text { welds and vessel surface }\end{array}$ \\
\hline $\begin{array}{l}\text { Feedwater pump tur- } \\
\text { bine annual inspec- } \\
\text { tion }\end{array}$ & Annually & $\mathrm{T}$ & $\begin{array}{l}\text { Open and inspect turbine steam flow path, check } \\
\text { bearings and blade wear, throttle valve internals, } \\
\text { carbon ring gland seals, and overspeed trip valve } \\
\text { internals }\end{array}$ \\
\hline $\begin{array}{l}\text { Feedwater pump tur- } \\
\text { bine steam strainer } \\
\text { clean and inspect }\end{array}$ & Annually & $\mathrm{T}$ & Clean and inspect the steam strainer \\
\hline $\begin{array}{l}\text { Feedwater pump tur- } \\
\text { bine overspeed trip } \\
\text { test }\end{array}$ & Monthly & $\mathrm{F}$ & Test turbine overspeed trip device \\
\hline $\begin{array}{l}\text { Feedwater pump tur- } \\
\text { bine monthly inspec- } \\
\text { tion }\end{array}$ & Monthly & $\mathrm{T}$ & $\begin{array}{l}\text { Check bearing housings, check oil rings, check } \\
\text { and lubricate throttle and overspeed trip linkage }\end{array}$ \\
\hline
\end{tabular}




\subsubsection{Condensate}

Periodic and condition based maintenance actions will be required to be performed on the condensate pumps. These items will include vibration analysis to determine bearing health, oil analysis on lubricating oil, replacement of seals and wear rings, periodic disassembly and inspection, turbine overhaul, etc.

The maintenance actions recommended below are not intended to be an exhaustive list, but to be used as a guide. These recommendations are based on past operating experience, judgment, and manufacturer's recommendations for similar systems. Table 21 lists the recommended condensate system maintenance schedule.

Table 21. Recommended condensate system maintenance.

\begin{tabular}{|c|c|c|c|}
\hline Maintenance action & Periodicity & Type* & Notes \\
\hline $\begin{array}{l}\text { Sodium cation pol- } \\
\text { isher resin replace- } \\
\text { ment }\end{array}$ & Every 5 yrs & $\mathrm{T}$ & $\begin{array}{l}\text { Sodium cation polisher resin replace- } \\
\text { ment (one unit at a time) }\end{array}$ \\
\hline $\begin{array}{l}\text { Sodium cation pol- } \\
\text { isher resin treatment }\end{array}$ & Annually & $\mathrm{T}$ & $\begin{array}{l}\text { Sodium cation polisher resin treatment } \\
\text { (one unit at a time) }\end{array}$ \\
\hline $\begin{array}{l}\text { Condensate pump } \\
\text { turbine Annual inspec- } \\
\text { tion }\end{array}$ & Annually & $\mathrm{T}$ & $\begin{array}{l}\text { Open and inspect turbine steam flow } \\
\text { path, check bearings and blade wear, } \\
\text { throttle valve internals, carbon ring } \\
\text { gland seals, and overspeed trip valve } \\
\text { internals }\end{array}$ \\
\hline $\begin{array}{l}\text { Condensate pump } \\
\text { turbine steam } \\
\text { strainer clean and } \\
\text { inspect }\end{array}$ & Annually & $\mathrm{T}$ & Clean and inspect the steam strainer \\
\hline $\begin{array}{l}\text { Condensate pump } \\
\text { turbine overspeed trip } \\
\text { test }\end{array}$ & Monthly & $\mathrm{F}$ & Test turbine overspeed trip device \\
\hline $\begin{array}{l}\text { Condensate pump } \\
\text { turbine monthly in- } \\
\text { spection }\end{array}$ & Monthly & $\mathrm{T}$ & $\begin{array}{l}\text { Check bearing housings, check oil } \\
\text { rings, check and lubricate throttle and } \\
\text { overspeed trip linkage }\end{array}$ \\
\hline
\end{tabular}

\subsubsection{Steam}

This steam system review is limited to related equipment inside of the CHPP. Maintenance of the district heating system is not considered in this report. Periodic and condition based maintenance actions such as the in- 
spection of carbon steel piping, the cleaning of steam traps, etc. will need to be performed.

The maintenance actions recommended below are not intended to be an exhaustive list, but to be used as a guide. These recommendations are based on past operating experience, judgment, and manufacturer's recommendations for similar systems. Table 22 lists The recommended steam system maintenance schedule.

Table 22. Recommended steam system maintenance

\begin{tabular}{|l|c|c|l|}
\hline \multicolumn{1}{|c|}{ Maintenance action } & Periodicity & Type* & \multicolumn{1}{c|}{ Notes } \\
\hline $\begin{array}{l}100 \text { psig system bellow expansion } \\
\text { joints inspection }\end{array}$ & Every 5 yrs & $\mathrm{T}$ & $\begin{array}{l}\text { Inspect expansion joints } \\
\text { and replace if required }\end{array}$ \\
\hline $\begin{array}{l}\text { Pressure reducing stations inspec- } \\
\text { tion }\end{array}$ & Annually & $\mathrm{T}$ & $\begin{array}{l}\text { Clean and inspect pressure } \\
\text { reducing stations }\end{array}$ \\
\hline $\begin{array}{l}\text { Control, shutoff and check valves } \\
\text { inspections }\end{array}$ & Annually & $\mathrm{T}$ & $\begin{array}{l}\text { Clean and Inspect valve } \\
\text { operation, seats and inter- } \\
\text { nals }\end{array}$ \\
\hline $\begin{array}{l}\text { * T-Time based (Preventative) maintenance item, P-Predictive maintenance item, F-Failure } \\
\text { finding maintenance item }\end{array}$
\end{tabular}

\subsubsection{Coal handling}

A major fire occurred in February 2006 in the south coal handling system. This fire caused extensive damage to that system such that it is no longer operational. At this time the cause of the fire is still under investigation and it is outside the scope of this study to speculate as to the reasons that the fire started. However, a comprehensive system of maintenance can likely mitigate the risk of such an event occurring in the future. The cleaning of coal dust accumulations from different points in the system and the testing and maintenance of fire suppression equipment aid in mitigating the risk of fire and / or explosion. The maintenance actions recommended below are not intended to be an exhaustive list, but to be used as a guide. These recommendations are based on past operating experience, judgment, and manufacturer's recommendations for similar systems. Table 23 lists the recommended coal handling system maintenance. 
Table 23. Recommended coal handling maintenance.

\begin{tabular}{|c|c|c|c|}
\hline Maintenance Action & Periodicity & Type* & Notes \\
\hline Inspect Crusher & Annually & $\mathrm{T}$ & $\begin{array}{l}\text { Inspect hammer and suspension bars, check } \\
\text { tightness and general condition of fasteners, } \\
\text { check shafts and pulleys }\end{array}$ \\
\hline $\begin{array}{l}\text { Inspect Crusher and } \\
\text { Conveyor Clutch As- } \\
\text { semblies }\end{array}$ & Annually & $\mathrm{T}$ & $\begin{array}{l}\text { Inspect Crusher and Conveyor Clutch Assem- } \\
\text { blies }\end{array}$ \\
\hline $\begin{array}{l}\text { Inspection of Wear } \\
\text { Parts }\end{array}$ & Annually & $\mathrm{T}$ & $\begin{array}{l}\text { Grizzlies, apron, belt cleaner and plows, } \\
\text { idlers, pulley assemblies, conveyor and feed- } \\
\text { ing belting, storage pile discharger, chutes, } \\
\text { magnetic separator, belt scale, duct collec- } \\
\text { tors, exhaust fan }\end{array}$ \\
\hline $\begin{array}{l}\text { Vibratory Feeder } \\
\text { Inspection }\end{array}$ & $\begin{array}{l}\text { Semi- } \\
\text { Annually }\end{array}$ & $\mathrm{T}$ & $\begin{array}{l}\text { Check all welds and general condition ensure } \\
\text { all vibrators are operating clean coal dust } \\
\text { build-up }\end{array}$ \\
\hline $\begin{array}{l}\text { Bucket Elevator In- } \\
\text { spection }\end{array}$ & $\begin{array}{l}\text { Semi- } \\
\text { Annually }\end{array}$ & $\mathrm{T}$ & $\begin{array}{l}\text { Check buckets, belt, bearings, and drives } \\
\text { clean coal dust build-up }\end{array}$ \\
\hline $\begin{array}{l}\text { Conveyor Belts In- } \\
\text { spection }\end{array}$ & Quarterly & $\mathrm{T}$ & $\begin{array}{l}\text { Inspect all conveyor belts, bearings, rollers } \\
\text { clean coal dust build-up }\end{array}$ \\
\hline $\begin{array}{l}\text { Fire Suppression } \\
\text { System Inspection }\end{array}$ & Quarterly & $F$ & $\begin{array}{l}\text { Inspect fire suppression system controls, pip- } \\
\text { ing, and equipment to ensure it is functioning } \\
\text { properly }\end{array}$ \\
\hline $\begin{array}{l}\text { Clean Conveyor Sys- } \\
\text { tem }\end{array}$ & Monthly & $\mathrm{T}$ & $\begin{array}{l}\text { Clean coal conveyor system and adjust belt } \\
\text { scrappers to prevent coal build-up }\end{array}$ \\
\hline
\end{tabular}

\subsubsection{Ash handling}

The maintenance actions recommended below are not intended to be an exhaustive list, but to be used as a guide. These recommendations are based on past operating experience, judgment, and manufacturer's recommendations for similar systems. Table 24 lists the recommended ash handling maintenance schedule.

Table 24. Recommended ash handling maintenance.

\begin{tabular}{|l|c|c|l|}
\hline \multicolumn{1}{|c|}{ Maintenance action } & Periodicity & Type* & \multicolumn{1}{|c|}{ Notes } \\
\hline Replace Bags & 5 yrs & T & Replace all bags in baghouse \\
\hline $\begin{array}{l}\text { Vacuum System Inspec- } \\
\text { tion }\end{array}$ & Annually & $\mathrm{T}$ & $\begin{array}{l}\text { Inspect vacuum system integrity espe- } \\
\text { cially elbows }\end{array}$ \\
\hline $\begin{array}{l}\text { Screw Conveyor Inspec- } \\
\text { tion }\end{array}$ & Annually & $\mathrm{T}$ & $\begin{array}{l}\text { Inspect screw conveyor mechanicals for } \\
\text { operation and check liner thickness }\end{array}$ \\
\hline $\begin{array}{l}\text { Valve Liner Inspection/ } \\
\text { Replacement }\end{array}$ & Annually & $\mathrm{T}$ & Valve Liner Inspection/ Replacement \\
\hline
\end{tabular}




\begin{tabular}{|l|c|c|l|}
\hline \multicolumn{1}{|c|}{ Maintenance action } & Periodicity & Type* $^{*}$ & \multicolumn{1}{c|}{ Notes } \\
\hline $\begin{array}{l}\text { Change Air Compressor } \\
\text { Oil }\end{array}$ & Quarterly & T & $\begin{array}{l}\text { Change the oil in the bag house air com- } \\
\text { pressors and send for analysis }\end{array}$ \\
\hline $\begin{array}{l}\text { Bottom Ash Unloader } \\
\text { Inspections }\end{array}$ & Monthly & $T$ & $\begin{array}{l}\text { Inspect the bottom ash gates, associ- } \\
\text { ated hydraulic lines and transport piping }\end{array}$ \\
\hline $\begin{array}{l}\text { * T-Time based (Preventative) maintenance item, P-Predictive maintenance item, F-Failure } \\
\text { finding maintenance item }\end{array}$ \\
\hline
\end{tabular}

\subsubsection{Cooling}

The immediacy of the replacement of the current water cooled surface condensers indicate that only minimal reactive maintenance should be performed to keep the units operating until all steam turbines are tied into the air cooled condenser.

The maintenance actions recommended below are not intended to be an exhaustive list, but to be used as a guide. These recommendations are based on past operating experience, judgment, and manufacturer's recommendations for similar systems. Table 25 lists the recommended cooling system maintenance schedule (GEA Power Cooling Systems September 1996).

Table 25. Recommended ACC system maintenance.

\begin{tabular}{|l|l|l|l|}
\hline \multicolumn{1}{|c|}{ Maintenance action } & Periodicity & \multicolumn{1}{|c|}{ Type $^{*}$} & \multicolumn{1}{c|}{ Notes } \\
\hline Condenser Inspection & Annually & T & $\begin{array}{l}\text { Check fan blade pitch, clean blades, clean } \\
\text { weep holes, clean motor, }\end{array}$ \\
\hline Air Ejector Inspection & Annually & T & $\begin{array}{l}\text { Inspect nozzles, inspect inter/after con- } \\
\text { denser for fouling }\end{array}$ \\
\hline Fin Cleaning & Annually & T & $\begin{array}{l}\text { High pressure water cleaning of fin tube } \\
\text { bundles }\end{array}$ \\
\hline Fastener Inspection & $\begin{array}{l}\text { Semi- } \\
\text { Annually }\end{array}$ & T & $\begin{array}{l}\text { Inspect all hold down fasteners, check for } \\
\text { corrosion and retorque }\end{array}$ \\
\hline $\begin{array}{l}\text { Air Ejector Steam Strainer } \\
\text { Clean and Inspect }\end{array}$ & $\begin{array}{l}\text { Semi- } \\
\text { Annually }\end{array}$ & T & $\begin{array}{l}\text { Air Ejector Steam Strainer Clean and In- } \\
\text { spect }\end{array}$ \\
\hline Vibration Switch Test & $\begin{array}{l}\text { Semi- } \\
\text { Annually }\end{array}$ & F & $\begin{array}{l}\text { Test vibration switches for proper function } \\
\text { tighten all hardware }\end{array}$ \\
\hline $\begin{array}{l}\text { Vacuum Decay Test } \\
\text { Monthly }\end{array}$ & F & $\begin{array}{l}\text { Perform vacuum decay test to ensure } \\
\text { proper function of air ejectors }\end{array}$ \\
\hline $\begin{array}{l}\text { * T-Time based (Preventative) maintenance item, P-Predictive maintenance item, F-Failure find- } \\
\text { ing maintenance item }\end{array}$
\end{tabular}




\subsubsection{Water treatment}

The maintenance actions recommended below are not intended to be an exhaustive list, but to be used as a guide. These recommendations are based on past operating experience, judgment, and manufacturer's recommendations for similar systems. Table 26 lists the recommended water treatment maintenance schedule.

Table 26. Recommended water treatment maintenance schedule.

\begin{tabular}{|l|c|c|l|}
\hline \multicolumn{1}{|c|}{ Maintenance Action } & Frequency & Type* & \multicolumn{1}{c|}{ Notes } \\
\hline RO Membrane CIP Procedure & Annually & $T$ & $\begin{array}{l}\text { Clean RO membranes in } \\
\text { accordance with the Clean } \\
\text { In Place (CIP) procedure }\end{array}$ \\
\hline $\begin{array}{l}\text { Plate and Frame Heat Exchanger } \\
\text { Cleaning }\end{array}$ & Annually & $T$ & $\begin{array}{l}\text { Disassemble, clean, and } \\
\text { inspect heat exchanger } \\
\text { plates, gaskets and pas- } \\
\text { sages }\end{array}$ \\
\hline $\begin{array}{l}\text { Pre-filtration Skid Media Re- } \\
\text { placement (sand-anthracite) }\end{array}$ & Every 5 yrs & $T$ & $\begin{array}{l}\text { Replace filter media in the } \\
\text { Pre-filter }\end{array}$ \\
\hline $\begin{array}{l}\text { RO Skid Membrane Replacement } \\
\text { Every 5 yrs }\end{array}$ & T & $\begin{array}{l}\text { Replace RO membranes for } \\
\text { all passes }\end{array}$ \\
\hline $\begin{array}{l}\text { * T-Time based (Preventative) maintenance item, P-Predictive maintenance item, F-Failure } \\
\text { finding maintenance item }\end{array}$ & \\
\hline
\end{tabular}

\subsubsection{Electrical}

The Power Plant Electrical system includes 12.47 kV, $4160 \mathrm{~V}, 2400 \mathrm{~V}, 480$ VAC, 120 VAC, and 125 VDC systems and a backup diesel generator for lighting. Tables 27 and 28 lists the recommended maintenance schedule and tests for the transformers, and Table 29 lists the recommended maintenance for the Electrical distribution system.

The maintenance actions recommended below are not intended to be an exhaustive list, but to be used as a guide. These recommendations are based on past operating experience, judgment, and manufacturer's recommendations for similar systems.

Table 27. Transformer inspection/maintenance program.

\begin{tabular}{|l|l|l|l|}
\hline Maintenance action & Periodicity & Type* & \multicolumn{1}{|c|}{ Notes } \\
\hline $\begin{array}{l}\text { Inspect for Sagging } \\
\text { or Damaged Cables }\end{array}$ & Annually & T & \\
\hline Protective Relays & Annually & F & $\begin{array}{l}\text { Calibrate protective relays and measure ratio } \\
\text { of CTs }\end{array}$ \\
\hline
\end{tabular}




\begin{tabular}{|l|l|l|l|}
\hline Maintenance action & Periodicity & Type* & \multicolumn{1}{|c|}{ Notes } \\
\hline Turns Ratio Test & Annually & P & Measure turns ratio \\
\hline $\begin{array}{l}\text { Ground and Power } \\
\text { Factor Test }\end{array}$ & Annually & P & $\begin{array}{l}\text { Conduct ground test, verify resistance to } \\
\text { ground is within acceptable range and meas- } \\
\text { ure insulation power factor }\end{array}$ \\
\hline Oil Sample & $\begin{array}{l}\text { Semi- } \\
\text { Annually }\end{array}$ & P & Oil sample for dissolved combustible gasses \\
\hline Bushing Inspection & $\begin{array}{l}\text { Semi- } \\
\text { Annually }\end{array}$ & T & $\begin{array}{l}\text { Inspect bushings and lightning arrestors for } \\
\text { contamination and cracks }\end{array}$ \\
\hline Oil Samples & Quarterly & P & See Table 27 \\
\hline Resistance Testing & $\begin{array}{l}\text { Quarterly } \\
\text { * T-Time based (Preventative) maintenance item, P-Predictive maintenance item, F-Failure } \\
\text { finding maintenance item }\end{array}$ & $\begin{array}{l}\text { Measure core ground resistance, winding } \\
\text { resistance, and resistance to ground }\end{array}$ \\
\hline
\end{tabular}

Table 28. Transformer tests list.

Quarterly Oil samples to be tested for:
a) Acidity
b) Interfacial tension
c) Dielectric Strength (D1816)
d) Water Content
e) Power Factor
f) Color

Table 29. Recommended electrical maintenance schedule.

\begin{tabular}{|c|c|c|c|}
\hline Maintenance Action & Periodicity & Type* & Notes \\
\hline Internal Inspection & Annually & $\mathrm{T}$ & $\begin{array}{l}\text { Inspect Internals of all switchgear, check bus } \\
\text { bars, insulations, cables, retorque bus con- } \\
\text { nectors }\end{array}$ \\
\hline Protective Relays & Annually & $\mathrm{F}$ & $\begin{array}{l}\text { Calibrate protective relays and measure ratio } \\
\text { of CTs }\end{array}$ \\
\hline $\begin{array}{l}\text { Circuit Breaker Test- } \\
\text { ing }\end{array}$ & Annually & $\mathrm{F}$ & $\begin{array}{l}\text { Rack out and inspect main circuit breakers, } \\
\text { lubricate operating mechanism, test inter- } \\
\text { locks and trips }\end{array}$ \\
\hline $\begin{array}{l}\text { Ground and Power } \\
\text { Factor Test }\end{array}$ & Annually & $\mathrm{P}$ & $\begin{array}{l}\text { Conduct ground test, verify resistance to } \\
\text { ground and between phases is within accept- } \\
\text { able range and measure insulation power } \\
\text { factor }\end{array}$ \\
\hline $\begin{array}{l}\text { Circuit Breaker In- } \\
\text { spection }\end{array}$ & Quarterly & $\mathrm{T}$ & $\begin{array}{l}\text { Inspect contact surfaces, linkages, arc chutes } \\
\text { and bus connection equipment }\end{array}$ \\
\hline $\begin{array}{l}\text { Diesel Engine Oil } \\
\text { Change }\end{array}$ & Quarterly & $\mathrm{P}$ & Change oil and send sample for analysis \\
\hline Cable Inspection & Monthly & $\mathrm{T}$ & $\begin{array}{l}\text { The plant will be broken down into } 12 \text { zones } \\
\text { and all external cables will be thermal } \\
\text { scanned and physically inspected. This is so } \\
\text { that all cables will be inspected once a year }\end{array}$ \\
\hline
\end{tabular}




\begin{tabular}{|l|c|c|l|}
\hline Maintenance Action & Periodicity & Type* $^{*}$ & \multicolumn{1}{|c|}{ Notes } \\
\hline $\begin{array}{l}\text { Instor Controller } \\
\text { Insection }\end{array}$ & Monthly & T & $\begin{array}{l}\text { The Plant will be broke down into six zones } \\
\text { and all motor controllers in one zone will be } \\
\text { cleaned and inspected per month. This is so } \\
\text { all Controllers will be inspected semi-annually }\end{array}$ \\
\hline $\begin{array}{l}\text { Battery Bank In- } \\
\text { spection }\end{array}$ & Monthly & T & $\begin{array}{l}\text { Both battery banks will be cleaned and in- } \\
\text { spected each month }\end{array}$ \\
\hline $\begin{array}{l}\text { Emergency Lighting } \\
\text { Test }\end{array}$ & Monthly & F & $\begin{array}{l}\text { Conduct test to ensure that diesel auto starts } \\
\text { and auto transfers. Verify that the generator } \\
\text { fuel tank has adequate fuel. }\end{array}$ \\
\hline $\begin{array}{l}\text { * T-Time based (Preventative) maintenance item, P-Predictive maintenance item, F-Failure } \\
\text { finding maintenance item }\end{array}$
\end{tabular}

\subsubsection{Instrumentation and control}

Proper calibration of the plant instrumentation is paramount to ensure correct decisions are made by the plant operators. Faulty calibration can lead to excessive loads on equipment and increased repair costs due to operating outside of equipment design specifications. Underutilization of equipment can also occur resulting in the loss of value and unnecessary use of additional equipment and energy. Having personnel properly trained and certified to perform calibrations is imperative to any operation. The expansion of the calibration program from just the EPA required instruments (Continuous Emissions Monitoring System, Continuous Opacity Monitoring System, Steam Flow Orifice, and Coal Scales) to all plant instrumentation including all flow, pressure, temperature, electrical, and metering instruments and associated control loops in the DCS. The use of plant instrumentation by both maintenance and operations to monitor trends needs to be addressed. The operators currently only monitor instantaneous data from the DCS and do not use the DCS' ability to trend that data overtime. Using the trending capability of the DCS would allow operators to take actions to stop plant excursions before they came near operating limits. The operators currently wait for alarms before taking corrective actions. Training in trend analysis would increase plant reliability by expanding the operations staff capability of addressing issues before they become large problems. Maintenance could also benefit from trend analysis from the DCS especially relating to the steam turbine generator bearings. The current vibration monitoring system is linked to the DCS and has the capability of being displayed in a trend to show when bearings are encountering problems. 
The DCS is a Westinghouse legacy system that is no longer supported by Westinghouse. Spare parts are expensive, require long lead times, or are unattainable. The CHPP staff would like it to be replaced with an updated system. This would also aid in the effort to create a preventative maintenance program by allowing easier collection of information from the DCS database to be analyzed to determine long-term trends in equipment performance. Tracking performance can indicate if a problem is developing with equipment. If a problem is indicated additional measures can be taken to identify and remedy the problem before it becomes a major performance or capability issue for the plant.

Recording and monitoring are equally important aspects of environmental permit compliance. Compliance with permit recording conditions would benefit if routine trend analyses were implemented. Because trending is not routine, the recording function of the DCS is often neglected. As such, recording of information required by the Title $\mathrm{V}$ permit can terminate and go uncorrected for an unfavorable period time, leading to large gaps in the permit-required data record. This has been a major cause of past violations. For this reason and due to the overall unreliability of the DCS and long lead times involved in repair, permit-required data should be fed to a second data logging system as backup until the DCS is replaced or a program is implemented to minimize gaps in the permit-required data record.

\subsection{Estimated budget}

Appendix D contains the recommended budget detailed by system and new technology (diagnostic equipment/tests). The estimated cost in constant 2006 dollars to operate the new RCM system is presented in Table 30. The apparent escalation shown in the budget is actually the increase in cost of repairs as the equipment ages and more problems are discovered with the equipment that requires repairs. The budget includes a contingency amount for unforeseen catastrophic failures that could occur. This amount is included to ensure the CHPP can mount a rapid response to any catastrophic failure. The contingency is separate so it can be applied to any system. The RCM approach to the maintenance program will not require extensive overhauls performed every few years, but calls for spreading this maintenance out over the years and only performing it when the equipment needs it. This results in the levelized budget numbers seen for the Steam Turbines and the Boilers. It is recommended that the Steam Tur- 
bines receive one additional (i.e., one last) major overhaul to bring the maintenance actions up to date. That is, it is recommended that they receive overhauls on the following schedule: Steam Turbine \# 5 in 2008, Steam Turbine \#4 2009, and Steam Turbine \#1 in 2010. Steam Turbine \#3 was just overhauled in 2005 (Personal communication with Pat Driscoll and Mike Meeks). If possible, this schedule could be accelerated to perform these overhauls while the turbines are in an extended outage for the ACC installation. That schedule is presented in Table 1 (p 12). The cost estimates provided in Table 30 are based on the overhauls being conducted on the 2008 to 2010 schedule.

The 2005 Budget presented in Table 2 (p 26) shows that the maintenance labor costs were approximately $\$ 930,000^{*}$ and the total maintenance related expenses were approximately $\$ 1,400,000$ (exclusive of reactive maintenance and repair costs, which were unavailable). The estimated budget presented in Table 30 for 2006 shows labor costs as $\$ 1,100,000$, which includes the additional staffing recommended earlier in this report. Table 30 also shows the total cost of implementing and operating the preventative maintenance system for the first year to be $\$ 5,730,000$ including labor, equipment, and training.

The lack of budgetary records regarding the maintenance of the equipment at the CHPP has required that the budget estimate be based on judgment and past operating experience on similar equipment. The budget is not intended to build on the $M \& R$ budget presented in the previous $M \& R$ report, but to be a standalone budget reflecting the cost to operate a RCM system. The budget has line items in the balance of plant section that show the cost of consumables and the budget has been developed with an accuracy of $+/-30$ to 35 percent. The scope of the estimated maintenance activities is limited to maintenance of the existing equipment. That is, future upgrades or modifications are not included in the budget. Excluded costs in this category, include, but are not limited to:

- future environment control equipment or increased maintenance to meet future environmental requirements

- future capacity to meet heating or electrical capacity needs.

* Maintenance crew labor of $\$ 875,692$ and electrician labor cost of $\$ 54,731$ totals $\$ 930,423$ for maintenance labor. 
Table 30. Estimated maintenance program cost summary (\$ 2006).

\begin{tabular}{|c|c|c|c|c|c|c|c|c|c|c|c|c|c|}
\hline \multirow[b]{2}{*}{ Year } & \multicolumn{13}{|c|}{ Estimated Maintenance Program Cost, (2006 dollars) } \\
\hline & 2006 & 2007 & 2008 & 2009 & 2010 & 2011 & 2012 & 2013 & 2014 & 2015 & 2016 & 2017 & 2018 \\
\hline Boilers 1 through 6 & $1,500,000$ & $1,500,000$ & $1,500,000$ & $1,500,000$ & $1,500,000$ & $1,320,000$ & $1,360,000$ & $1,400,000$ & $1,430,000$ & $1,470,000$ & $1,520,000$ & $1,560,000$ & $1,600,000$ \\
\hline \multicolumn{14}{|l|}{ Steam Turbine } \\
\hline ST 1 & 200,000 & 100,000 & 125,000 & 129,000 & $1,133,000$ & 137,000 & 141,000 & 145,000 & 149,000 & 154,000 & 158,000 & 163,000 & 168,000 \\
\hline ST 3 & 200,000 & 100,000 & 125,000 & 129,000 & 133,000 & 137,000 & 141,000 & 145,000 & 149,000 & 154,000 & 158,000 & 163,000 & 168,000 \\
\hline ST 4 & 200,000 & 100,000 & 125,000 & $1,129,000$ & 133,000 & 137,000 & 141,000 & 145,000 & 149,000 & 154,000 & 158,000 & 163,000 & 168,000 \\
\hline ST 5 & 200,000 & 100,000 & $1,125,000$ & 129,000 & 133,000 & 137,000 & 141,000 & 145,000 & 149,000 & 154,000 & 158,000 & 163,000 & 168,000 \\
\hline Subtotal Steam Turbine & 800,000 & 400,000 & $1,500,000$ & $1,515,000$ & $1,530,000$ & 546,000 & 563,000 & 580,000 & 597,000 & 615,000 & 633,000 & 652,000 & 672,000 \\
\hline \multicolumn{14}{|l|}{ Balance of Plant } \\
\hline Coal Handling System & 173,000 & 173,000 & 173,000 & 173,000 & 173,000 & 176,000 & 176,000 & 176,000 & 176,000 & 176,000 & 172,000 & 172,000 & 172,000 \\
\hline Ash System (including Baghouse/ID Fan/Env Cont) & 161,000 & 161,000 & 161,000 & 161,000 & 161,000 & 118,000 & 118,000 & 118,000 & 118,000 & 118,000 & 108,000 & 108,000 & 108,000 \\
\hline Steam Piping System & 107,000 & 107,000 & 107,000 & 107,000 & 107,000 & 50,000 & 50,000 & 50,000 & 50,000 & 50,000 & 50,000 & 50,000 & 50,000 \\
\hline Feedwater / Condensate System & 63,000 & 63,000 & 63,000 & 63,000 & 63,000 & 73,000 & 73,000 & 73,000 & 73,000 & 73,000 & 73,000 & 73,000 & 73,000 \\
\hline Cooling System & 187,000 & 187,000 & 187,000 & 187,000 & 187,000 & 44,000 & 44,000 & 44,000 & 44,000 & 44,000 & 30,000 & 30,000 & 30,000 \\
\hline Water Treatment System & 98,000 & 98,000 & 98,000 & 98,000 & 98,000 & 34,000 & 34,000 & 34,000 & 34,000 & 34,000 & 32,000 & 32,000 & 32,000 \\
\hline Instrumentation / Control Systems & 99,000 & 100,000 & 101,000 & 101,000 & 102,000 & 32,000 & 33,000 & 34,000 & 35,000 & 37,000 & 108,000 & 110,000 & 111,000 \\
\hline Electrical Distribution System & 115,000 & 117,000 & 118,000 & 120,000 & 121,000 & 53,000 & 55,000 & 56,000 & 58,000 & 60,000 & 92,000 & 94,000 & 96,000 \\
\hline Maintenance Shop Equipment, Small Tools, etc. & 15,000 & 15,000 & 16,000 & 16,000 & 17,000 & 17,000 & 18,000 & 18,000 & 19,000 & 20,000 & 20,000 & 21,000 & 21,000 \\
\hline Maintenance Consumables & 40,000 & 41,000 & 42,000 & 44,000 & 45,000 & 46,000 & 48,000 & 49,000 & 51,000 & 52,000 & 54,000 & 55,000 & 57,000 \\
\hline Subtotal Balance of Plant & $1,060,000$ & $1,060,000$ & $1,070,000$ & $1,070,000$ & $1,070,000$ & 640,000 & 650,000 & 650,000 & 660,000 & 660,000 & 740,000 & 740,000 & 750,000 \\
\hline \multicolumn{14}{|l|}{ NewTechnology } \\
\hline Computerized Maintenance Management System & 100,000 & 20,000 & 20,000 & 20,000 & 20,000 & 20,000 & 20,000 & 20,000 & 20,000 & 20,000 & 20,000 & 20,000 & 20,000 \\
\hline Vibration Analysis Systems & 24,000 & 2,000 & 2,000 & 2,000 & 2,000 & 2,000 & 2,000 & 2,000 & 2,000 & 2,000 & 24,000 & 2,000 & 2,000 \\
\hline Thermal Imaging & 20,000 & 2,000 & 2,000 & 2,000 & 2,000 & 2,000 & 2,000 & 2,000 & 2,000 & 2,000 & 20,000 & 2,000 & 2,000 \\
\hline Ultrasonic & 12,000 & 2,000 & 2,000 & 2,000 & 2,000 & 2,000 & 2,000 & 2,000 & 2,000 & 2,000 & 12,000 & 2,000 & 2,000 \\
\hline Oil Analysis & 11,000 & 11,000 & 11,000 & 11,000 & 11,000 & 11,000 & 11,000 & 11,000 & 11,000 & 11,000 & 11,000 & 11,000 & 11,000 \\
\hline Subtotal New Technology & 167,000 & 37,000 & 37,000 & 37,000 & 37,000 & 37,000 & 37,000 & 37,000 & 37,000 & 37,000 & 87,000 & 37,000 & 37,000 \\
\hline Subtotal CHPP Bare Erected Costs & $3,530,000$ & $3,000,000$ & $4,100,000$ & $4,120,000$ & $4,140,000$ & $2,550,000$ & $2,610,000$ & $2,670,000$ & $2,730,000$ & $2,790,000$ & $2,970,000$ & $2,990,000$ & $3,060,000$ \\
\hline Owner's Costs (Engineering @ 5\%) & 176,000 & 150,000 & 205,000 & 206,000 & 207,000 & 127,000 & 130,000 & 133,000 & 136,000 & 139,000 & 149,000 & 150,000 & 153,000 \\
\hline Subtotal Bare Erected Costs and Omner's Costs & $3,700,000$ & $3,150,000$ & $4,310,000$ & $4,330,000$ & $4,350,000$ & $2,680,000$ & $2,740,000$ & $2,800,000$ & $2,860,000$ & $2,930,000$ & $3,120,000$ & $3,140,000$ & $3,210,000$ \\
\hline Project Contingency & 930,000 & 790,000 & $1,080,000$ & $1,080,000$ & $1,090,000$ & 800,000 & 820,000 & 840,000 & 860,000 & 880,000 & $1,090,000$ & $1,100,000$ & $1,120,000$ \\
\hline Total Plant Maintenance Cost (excluding Staffing) & $4,630,000$ & $3,940,000$ & $5,390,000$ & $5,410,000$ & $5,440,000$ & $3,480,000$ & $3,560,000$ & $3,640,000$ & $3,720,000$ & $3,810,000$ & $4,220,000$ & $4,240,000$ & $4,340,000$ \\
\hline Total Plant Labor Cost (Recommended Staffing) & $1,100,000$ & $1,100,000$ & $1,100,000$ & $1,100,000$ & $1,100,000$ & $1,100,000$ & $1,100,000$ & $1,100,000$ & $1,100,000$ & $1,100,000$ & $1,100,000$ & $1,100,000$ & $1,100,000$ \\
\hline Total Plant Cost & $5,730,000$ & $5,040,000$ & $6,480,000$ & $6,510,000$ & $6,540,000$ & $4,580,000$ & $4,660,000$ & $4,740,000$ & $4,820,000$ & $4,910,000$ & $5,320,000$ & $5,340,000$ & $5,440,000$ \\
\hline
\end{tabular}


Table 30. Estimated maintenance program cost summary (\$ 2006) (cont'd).

\begin{tabular}{|c|c|c|c|c|c|c|c|c|c|c|c|c|c|}
\hline \multirow[b]{2}{*}{ Year } & \multicolumn{13}{|c|}{ Estimated Maintenance Program Cost, (2006 dollars) } \\
\hline & 2019 & 2020 & 2021 & 2022 & 2023 & 2024 & 2025 & 2026 & 2027 & 2028 & 2029 & 2030 & Total \\
\hline Boilers 1 through 6 & $1,650,000$ & $1,690,000$ & $1,640,000$ & $1,680,000$ & $1,740,000$ & $1,790,000$ & $1,840,000$ & $1,900,000$ & $1,950,000$ & $2,010,000$ & $2,070,000$ & $2,130,000$ & $41,250,000$ \\
\hline \multicolumn{14}{|l|}{ Steam Turbine } \\
\hline ST 1 & 173,000 & 178,000 & 184,000 & 189,000 & 195,000 & 201,000 & 207,000 & 213,000 & 219,000 & 226,000 & 233,000 & 240,000 & $5,357,000$ \\
\hline ST 3 & 173,000 & 178,000 & 184,000 & 189,000 & 195,000 & 201,000 & 207,000 & 213,000 & 219,000 & 226,000 & 233,000 & 240,000 & $4,357,000$ \\
\hline ST 4 & 173,000 & 178,000 & 184,000 & 189,000 & 195,000 & 201,000 & 207,000 & 213,000 & 219,000 & 226,000 & 233,000 & 240,000 & $5,357,000$ \\
\hline ST 5 & 173,000 & 178,000 & 184,000 & 189,000 & 195,000 & 201,000 & 207,000 & 213,000 & 219,000 & 226,000 & 233,000 & 240,000 & $5,357,000$ \\
\hline Subtotal Steam Turbine & 692,000 & 713,000 & 734,000 & 756,000 & 779,000 & 802,000 & 826,000 & 851,000 & 877,000 & 903,000 & 930,000 & 958,000 & $20,426,000$ \\
\hline \multicolumn{14}{|l|}{ Balance of Plant } \\
\hline Coal Handling System & 172,000 & 172,000 & 176,000 & 176,000 & 176,000 & 176,000 & 176,000 & 176,000 & 176,000 & 176,000 & 176,000 & 176,000 & $4,361,000$ \\
\hline Ash System (including Baghouse/ID Fan/Env Cont) & 108,000 & 108,000 & 108,000 & 108,000 & 108,000 & 108,000 & 108,000 & 108,000 & 108,000 & 108,000 & 108,000 & 108,000 & $3,021,000$ \\
\hline Steam Piping System & 50,000 & 50,000 & 46,000 & 46,000 & 46,000 & 46,000 & 46,000 & 48,000 & 48,000 & 48,000 & 48,000 & 48,000 & $1,502,000$ \\
\hline Feedwater / Condensate System & 73,000 & 73,000 & 49,000 & 49,000 & 49,000 & 49,000 & 49,000 & 77,000 & 77,000 & 77,000 & 77,000 & 77,000 & $1,669,000$ \\
\hline Cooling System & 30,000 & 30,000 & 44,000 & 44,000 & 44,000 & 44,000 & 44,000 & 66,000 & 66,000 & 66,000 & 66,000 & 66,000 & $1,857,000$ \\
\hline Water Treatment System & 32,000 & 32,000 & 21,000 & 21,000 & 21,000 & 21,000 & 21,000 & 44,000 & 44,000 & 44,000 & 44,000 & 44,000 & $1,146,000$ \\
\hline Instrumentation / Control Systems & 112,000 & 113,000 & 44,000 & 45,000 & 46,000 & 48,000 & 49,000 & 121,000 & 123,000 & 125,000 & 126,000 & 128,000 & $2,084,000$ \\
\hline Electrical Distribution System & 98,000 & 100,000 & 71,000 & 73,000 & 75,000 & 78,000 & 80,000 & 82,000 & 85,000 & 87,000 & 90,000 & 92,000 & $2,167,000$ \\
\hline Maintenance Shop Equipment, Small Tools, etc. & 22,000 & 23,000 & 23,000 & 24,000 & 25,000 & 26,000 & 26,000 & 27,000 & 28,000 & 29,000 & 30,000 & 30,000 & 547,000 \\
\hline Maintenance Consumables & 59,000 & 61,000 & 62,000 & 64,000 & 66,000 & 68,000 & 70,000 & 72,000 & 74,000 & 77,000 & 79,000 & 81,000 & $1,458,000$ \\
\hline Subtotal Balance of Plant & 760,000 & 760,000 & 650,000 & 650,000 & 660,000 & 660,000 & 670,000 & 820,000 & 830,000 & 840,000 & 840,000 & 850,000 & $19,810,000$ \\
\hline \multicolumn{14}{|l|}{ New Technology } \\
\hline Computerized Maintenance Management System & 20,000 & 20,000 & 20,000 & 20,000 & 20,000 & 20,000 & 20,000 & 20,000 & 20,000 & 20,000 & 20,000 & 20,000 & 580,000 \\
\hline Vibration Analysis Systems & 2,000 & 2,000 & 2,000 & 2,000 & 2,000 & 2,000 & 2,000 & 24,000 & 2,000 & 2,000 & 2,000 & 2,000 & 116,000 \\
\hline Thermal Imaging & 2,000 & 2,000 & 2,000 & 2,000 & 2,000 & 2,000 & 2,000 & 20,000 & 2,000 & 2,000 & 2,000 & 2,000 & 103,000 \\
\hline Ultrasonic & 2,000 & 2,000 & 2,000 & 2,000 & 2,000 & 2,000 & 2,000 & 12,000 & 2,000 & 2,000 & 2,000 & 2,000 & 80,000 \\
\hline Oil Analysis & 11,000 & 11,000 & 11,000 & 11,000 & 11,000 & 11,000 & 11,000 & 11,000 & 11,000 & 11,000 & 11,000 & 11,000 & 285,000 \\
\hline Subtotal New Technology & 37,000 & 37,000 & 37,000 & 37,000 & 37,000 & 37,000 & 37,000 & 87,000 & 37,000 & 37,000 & 37,000 & 37,000 & $1,164,000$ \\
\hline Subtotal CHPP Bare Erected Costs & $3,130,000$ & $3,200,000$ & $3,050,000$ & $3,130,000$ & $3,210,000$ & $3,290,000$ & $3,380,000$ & $3,660,000$ & $3,700,000$ & $3,790,000$ & $3,880,000$ & $3,980,000$ & $82,650,000$ \\
\hline Ouner's Costs (Engineering @ 5\%) & 157,000 & 160,000 & 153,000 & 156,000 & 160,000 & 165,000 & 169,000 & 183,000 & 185,000 & 189,000 & 194,000 & 199,000 & $4,133,000$ \\
\hline Subtotal Bare Erected Costs and Ouner's Costs & $3,290,000$ & $3,360,000$ & $3,210,000$ & $3,290,000$ & $3,370,000$ & $3,460,000$ & $3,540,000$ & $3,840,000$ & $3,880,000$ & $3,980,000$ & $4,080,000$ & $4,180,000$ & $86,790,000$ \\
\hline Project Contingency & $1,150,000$ & $1,180,000$ & $1,280,000$ & $1,310,000$ & $1,350,000$ & $1,380,000$ & $1,420,000$ & $1,540,000$ & $1,550,000$ & $1,590,000$ & $1,630,000$ & $1,670,000$ & $29,530,000$ \\
\hline Total Plant Maintenance Cost (excluding Staffing) & $4,440,000$ & $4,540,000$ & $4,490,000$ & $4,600,000$ & $4,720,000$ & $4,840,000$ & $4,960,000$ & $5,380,000$ & $5,430,000$ & $5,570,000$ & $5,710,000$ & $5,850,000$ & $116,320,000$ \\
\hline Total Plant Labor Cost (Recommended Staffing) & $1,100,000$ & $1,100,000$ & $1,100,000$ & $1,100,000$ & $1,100,000$ & $1,100,000$ & $1,100,000$ & $1,100,000$ & $1,100,000$ & $1,100,000$ & $1,100,000$ & $1,100,000$ & $27,470,000$ \\
\hline Total Plant Cost & $5,540,000$ & $5,640,000$ & $5,590,000$ & $5,700,000$ & $5,820,000$ & $5,940,000$ & $6,060,000$ & $6,470,000$ & $6,530,000$ & $6,670,000$ & $6,810,000$ & $6,950,000$ & $143,790,000$ \\
\hline
\end{tabular}


Notes / Clarifications:

1. Asbestos Abatement: No asbestos abatement costs have been included in this analysis, as it is assumed that past refurbishment projects have previously removed the asbestos containing materials (Alaska District August 1998) documented a total plant asbestos abatement cost of \$1.5 million.

2. Lead Abatement: No lead containing paint (LCP) abatement costs have been included in this analysis, as it is assumed that past refurbishment projects have previously removed the LCP.

3. In general, WorleyParsons used two sources of cost estimates to develop the estimated costs. 1. Those developed in-house by WorleyParsons, and 2. Those previously estimated for Ft Wainuright (Alaska District August 1998). The values in this reference were escalated from 1998 dollars to 2006 dollars by a 1.25 escalation factor.

4. Maintenance Labor: Routine maintenance is assumed to be performed by plant personnel. Major overhauls, such as the steam turbine overhauls and boiler overhauls are assumed to be performed by outside contractors.

5. Imported Labor: No costs (e.g., travel, per diem, wage premium) for imported labor have been assumed. It is assumed that the local labor force will be able to satisfy the skilled labor requirements.

6. Overhead and Profit: For the estimates developed by WorleyParsons, the overhead and profit were estimated as 8 and $10 \%$ respectively. The corresponding information was not detailed by Reference (Alaska District August 1998)

7. Engineering costs. The Contractor's engineering costs are included. The Ommer's engineering costs are included and limited to procurement and construction support and estimated at $5 \%$ of bare erected cost.

8. Project Management (PM) Costs: PM costs for the contractors are included. PM costs of the Omner are not included.

9. Contingency. A contingency level of 25 to $40 \%$ has been assumed to cover the design \& construction contingencies and the uncertainties of predicting maintenance and repair requirements 5 to 20 years into the future. To capture an increasing uncertainty with time, the following time dependent contingency factors were used: [2006-10: 25\%; 2011-15: 30\%; 2016-20: 35\%; 2021-30: 40\%]

10. Rounding. The above values might not necessary sum up to the indicated totals due to rounding

11. The replacement cost of the $12.47 \mathrm{KV}$ switchgear and associated equipment is not included in this budget estimate, because that scope is captured under the electrical distribution study.

12.The line labeled "Total Plant Labor Cost" represents in-house staffing costs. Labor included in other maintenance cost areas is contracted labor. 


\section{Conclusions and Recommendations}

\subsection{Conclusions}

This work has:

1. Assessed the state of the maintenance management system at the CHPP at Fort Wainwright, AK

2. Identified areas in the current process requiring improvement

3. Recommended changes to implement these improvements

4. Produced proposed maintenance schedules for the major systems

5. Estimated staffing requirements, materials, and equipment required for the maintenance program

6. Estimated a budget required to execute the recommended program over a period of 25 years.

The following section details the recommendations.

\subsection{Recommendations}

This study recommends that:

1. The existing maintenance program is too reactive; it should be transitioned to a proactive, Reliability Centered Maintenance (RCM) system. This work recommends that the CHPP adopt a RCM approach as detailed in Section 6.1 (p 52).

2. Long range planning be addressed at the Plant Management level for large maintenance actions and for outage planning. Major equipment must be overhauled on a regular basis to maintain plant efficiency and re-liability. Section 6.2 (p 55) describes a general RCM implementation, and Section 6.2.2 (p 58) details a system-specific implementation schedule.

3. A consistent budget be prepared to identify the costs of planned overhauls, major maintenance, regular maintenance actions, and day-today consumables. Section 6.3 (p 69) details an estimated budget.

4. Operations and maintenance training and manning be addressed to ensure that the plant has the proper number and properly trained personnel to operate and maintain the plant. Adding an overall Maintenance Manager/Planner will greatly increase the tracking of mainte- 
nance actions and productivity of the maintenance department. The addition of an EI\&C Supervisor will help the EI\&C department coordinate and plan work better to keep items from falling through the crack and coordinating maintenance schedules. The implementation of a RCM program will include an increase in the workload of the Mechanical Maintenance Technicians as well. The addition of two more experienced Mechanical Maintenance Technicians will provide enough additional manpower to cover this workload. The last manning item involves filling the two open EI\&C positions with experienced technicians. Table 5 (p 33) lists the recommended manning additions.

5. The CHPP undertake a formal training and qualification program including Standard Operating Procedures (SOP) and Emergency Operating Procedures (EOP) that would set a standard and provide a means of consistently training new operators and technicians. The cross training of maintenance personnel as operators would add the benefit of maintenance personnel better understanding the impact of faulty equipment on operations. Original Equipment Manufacturer (OEM) training needs to be done to ensure maintenance personnel can perform all job functions at the desired level of technical competency. OEM training allows the technician to understand how the equipment operates and how it is put together before the item breaks. The time for a technician to learn how an item works and its required maintenance procedures is not after the item has failed. OEM training can also impart helpful troubleshooting tips to speed the troubleshooting and repair process.

6. All manuals be maintained onsite. Interviews with the technicians revealed that new technical manuals are kept by the Army Corps of Engineer's office at Fort Wainwright only until the equipment warranty period is over, or if the CHPP personnel have a defined need for them. This slows down the troubleshooting and repair process and prevents technicians and operators from studying the manuals. The plant needs to establish an organized technical library and keep all pertinent drawings on site. All operators and technicians need to be trained in the use and importance of the plant Piping and Instrumentation Diagrams (P\&IDs). 


\section{References}

Alaska District, U.S. Army Corps of Engineers. 1998. Revitalization of the CHPP Fort Wainwright, Alaska. Contract DACA85-97-C-0033.

Bowman, Lyndell, and Moshage, Ralph E.. 1994. Improved maintenance management for Army central energy plants. Special Report FE-94/03/ADA276909.a. Champaign, IL: Construction Engineering Research Laboratory.

Brown, William. 2006. Mail correspondence. 28 March 2006.

Defense Energy Support Center (DEFC). 2005. Section J 9 - Central heat \& power plant and distribution system utilities privatization, Fort Wainwright, AK. www.desc.dla.mil/DCM/Files/J9\%20CHPP\%20FWA.pdf.

DPSI. 2007. Maintenance management software that works as hard as you do. http://www.dpsi.com/products/overview.asp?prod=iMaint\&sec=0verview.

Driscoll, Pat, and Meeks, Mike. Personal communication.

Environmental conservation air quality operating permit. 2003. No. 236TVPo1 Application No.000236. Issue Date: 14 April 2003; Expiration Date: 13 May 2008.

Fort Wainwright, AK. 2004. Assurance plan for continuous emission monitoring systems (CEMS) central heat and power plant.

GEA Power Cooling Systems. 1996. Operation and maintenance manual for the air cooled condenser.

H. W. Beecher Architects-Engineers. 1952. Power plant extension heat balances. Drawing 26-03-11, sheet 73. Rev. 22 July 1952.

Headquarters, Department of the Army (HQDA). 2005. Utility services. Army Regulation (AR) 420-49.

Jaeke, Darrell. Personal communication with U.S. Army Corps of Engineers Project Manager for ACC.

Lemay, Vic, and Brenner, Dave. Telephone conversation. 2005. Fort Wainwright, AL. 12 April 2005

Lemay, Vic. Personal communciation with Vic Lemay, Plant Engineer, Fort Wainwright, AK.

Levitt, Joel. 2003. Complete guide to preventive and predictive maintenance. New York: Industrial Press.

Moubray, John. 1997. Reliability centered maintenance. New York: Industrial Press. 
MRO software. 2007. Maximo asset management. http://www.mro.com/corporate/mrosolutions/index.php.

Personal communication with operator. 2006. Note: Operators provided information on condition of anonymity. Week of 27 March 2006.

POLARIS Laboratories, Inc. 2007. http://www.Polarislabs1.Com/

Raytheon Engineers and Constructors. 1996. Central heating and power plant refurbishment study. Technical Report 96-MB-17L.

Raytheon Engineers and Constructors. 1996. Central heating and power plant refurbishment study. Technical Report 96-MB-17L.

Smith, Anthony, and Hinchcliffe, Glenn. 2004. RCM-gateway to world class maintenance. Elsevier Butterworth-Heinemann.

U.S. Army Corps of Engineers Alaska District. 2005. Project status update. FTW 183.

U.S. Army Corps of Engineers, Alaska District. 20 September 2004. Solicitation offer and award - Fort Wainwright CHPP cooling system. Contract W911KB-04-C-0027, U.S. Army Corps of Engineers, Alaska District.

U.S. Army Corps of Engineers. 200o. Upgrade of CHPP—make-up water treatment system flow diagram. Drawing M12-1, sheet 113.

U.S. Army Corps of Engineers. CHPP upgrade - 100 psig steam system schematic. Drawing M7-1, sheet 90.

U.S. Army Corps of Engineers. CHPP upgrade -400 psig steam schematic. Drawing M61 , sheet 87 .

U.S. Environmental Protection Agency (USEPA), Office of Air Quality Planning and Standards (OAQPS). 1997. Fabric filter bag leak detection guidance. EPA454/R-98-015.

Vavrin, John L. 2 June 2006. E-mail correspondence.

Vavrin, John L., Brown, William T., Kemme, Michael R., Allen, Marcus A., Percle, Wayne J., Lorand, Robert T., Stauffer, David B., and Hudson, Kenneth. 2007. Electrical assessment, capacity, and demand study for Fort Wainwright, Alaska. ERDC/CERL TR-07-36. Champaign, IL: Construction Engineering Research Laboratory.

Vavrin, John L., Kemme, Michael R., Brown, William T., Boddu, Veera, Phetteplace, Gary E., Bonk, Donald L., Westerman, John, Lorand, Robert T., Vaysman, Vladimir, Stauffer, David, Hudson, Kenneth, DeLallo, Michael, and Buchanan, Thomas. 2006. Technology requirements study for a new central heating and power plant at Fort Wainwright, AK, ERDC TR-o6-8, Champaign, IL: Construction Engineering Research Laboratory. 


\section{Appendix A: Sample E\&IC and Mechanical Log Entries}

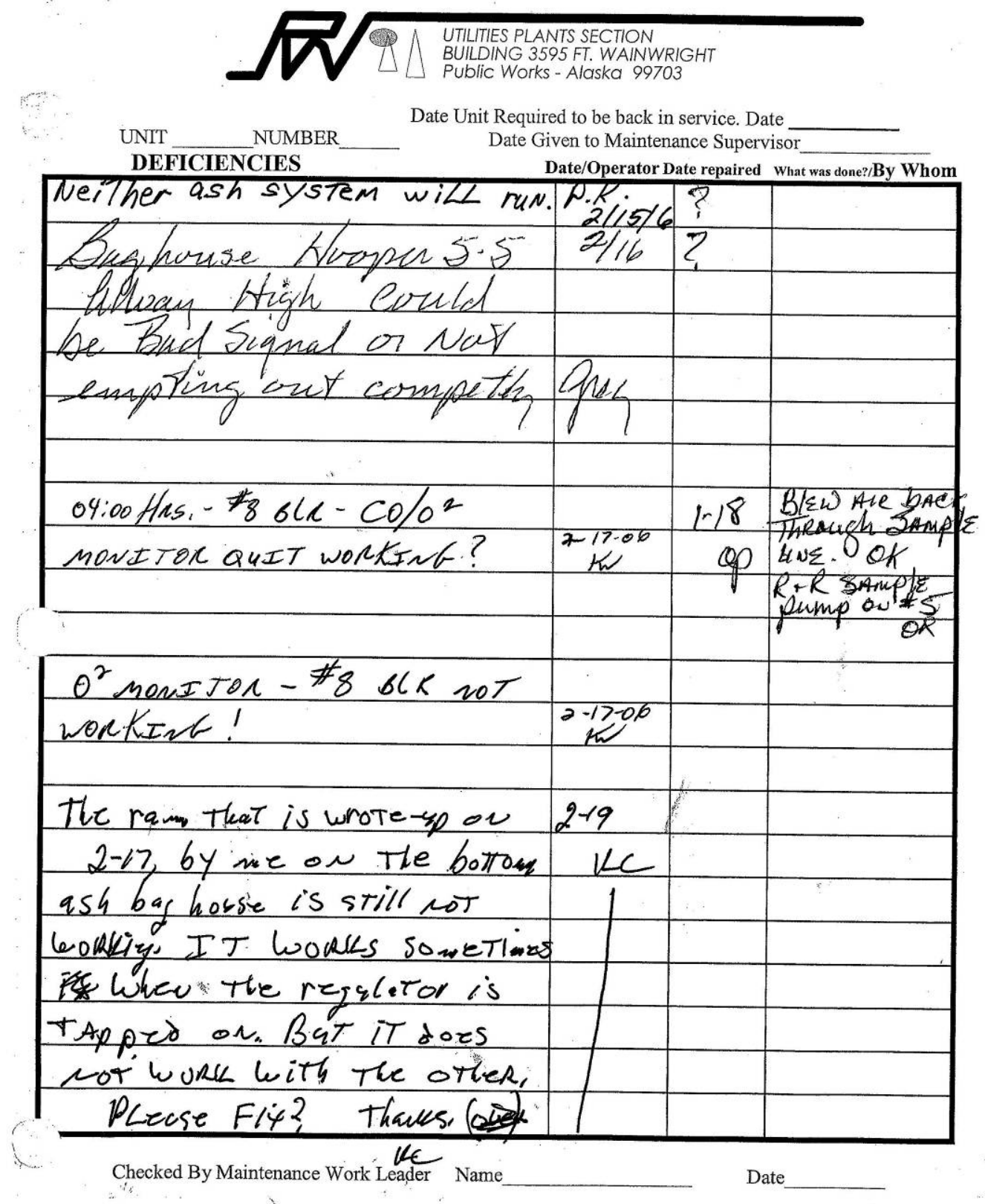

Figure A1. Example E\&IC log. 
ERDC/CERL TR-07-35

79

$18-066^{\text {th }}$ flook Exhurter

\# 1 outside Beatt is

Loose. Please Check

heforre symping uplaban

ok p

troopuch

1-8-06 $6^{\text {th }}$ Flook Coal

Crews' Storege Room

Elbow is Bloroling Stern

1-9 outside Feny vecorder gll

on TG control panel inop.

1-9-06 BCL:A3-STOKER

\#3-FEEDER CHADIN BROKE

Q 02:30thes. Th

1-9-06 $4^{\text {th }}$ Flook Boiler

\# 4 Dorth DRum Vent

Line an Elbow is Blowiges

Steam

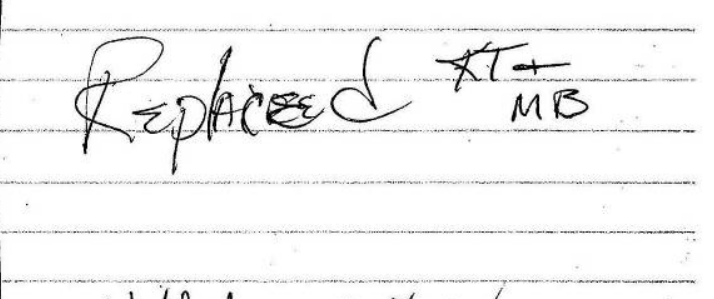

$O K K^{M B}$

1-9-06 $4^{\text {th }}$ Ploor Bolier

Welded 1.11.06

\# 4 NoRth Whistle

Stuck open

1-9-ole 4th Flook

Boilek \# F Firiekex, supper

heater Seann Bloreling

Mish from Center to

North End of five bat.

(2) Iea hole in five box Blowing Dust Head to be culdad / flusged.

(3) South End between 2. Supper Hteater Blowing Ifsh, Itll durning

Dustain Tub. Ash pilling upe

welded

$1-11-06 \mathrm{jM}$

ok nos

N

I. . .

Wh 


\section{Appendix B: Sample CHPP Monthly Inspection and Lubrication Checklist}

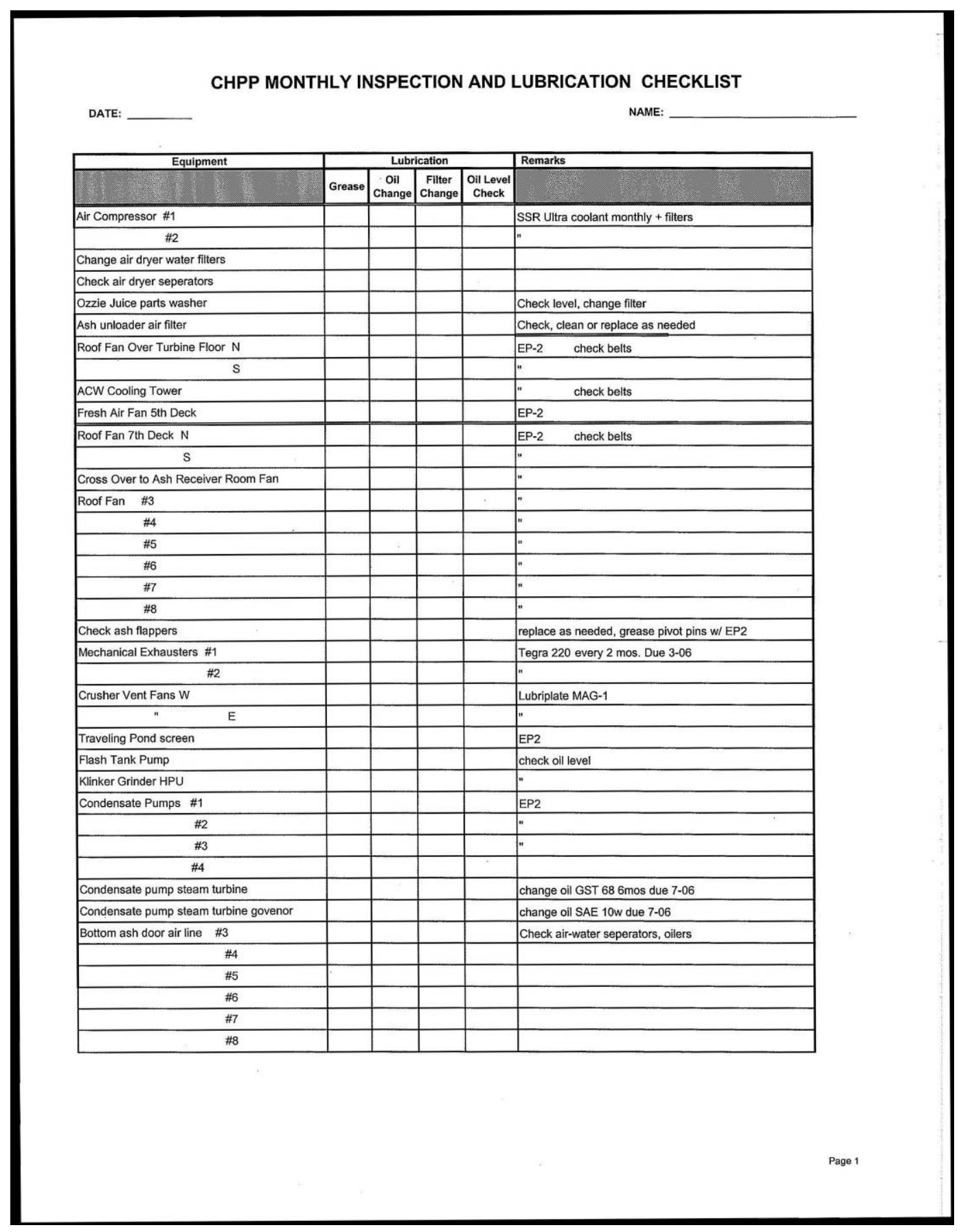

Figure B1. CHPP monthly inspection and lubrication checklist. 


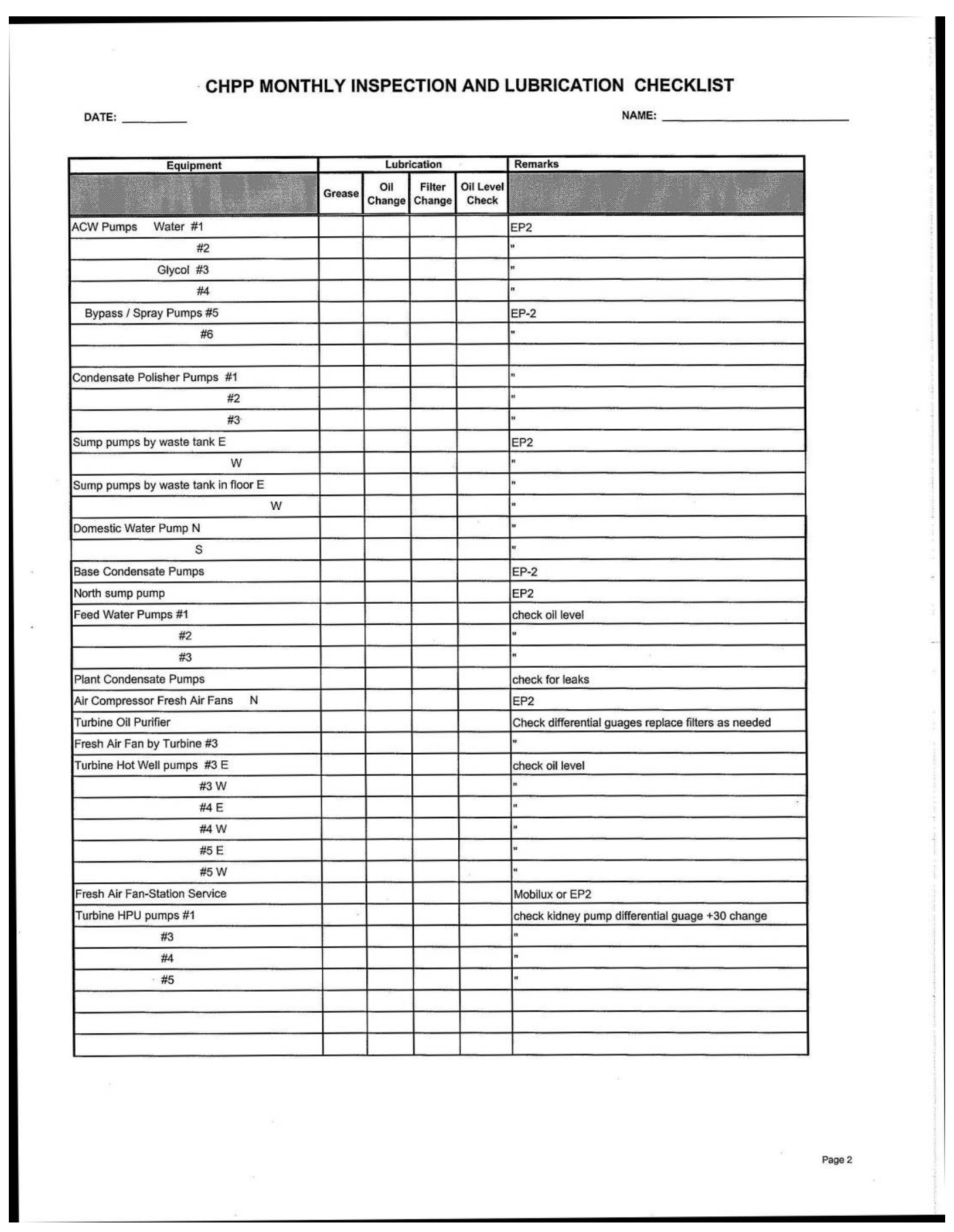

Figure B1. (cont'd). 


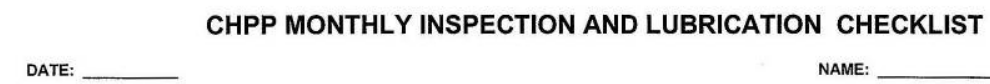

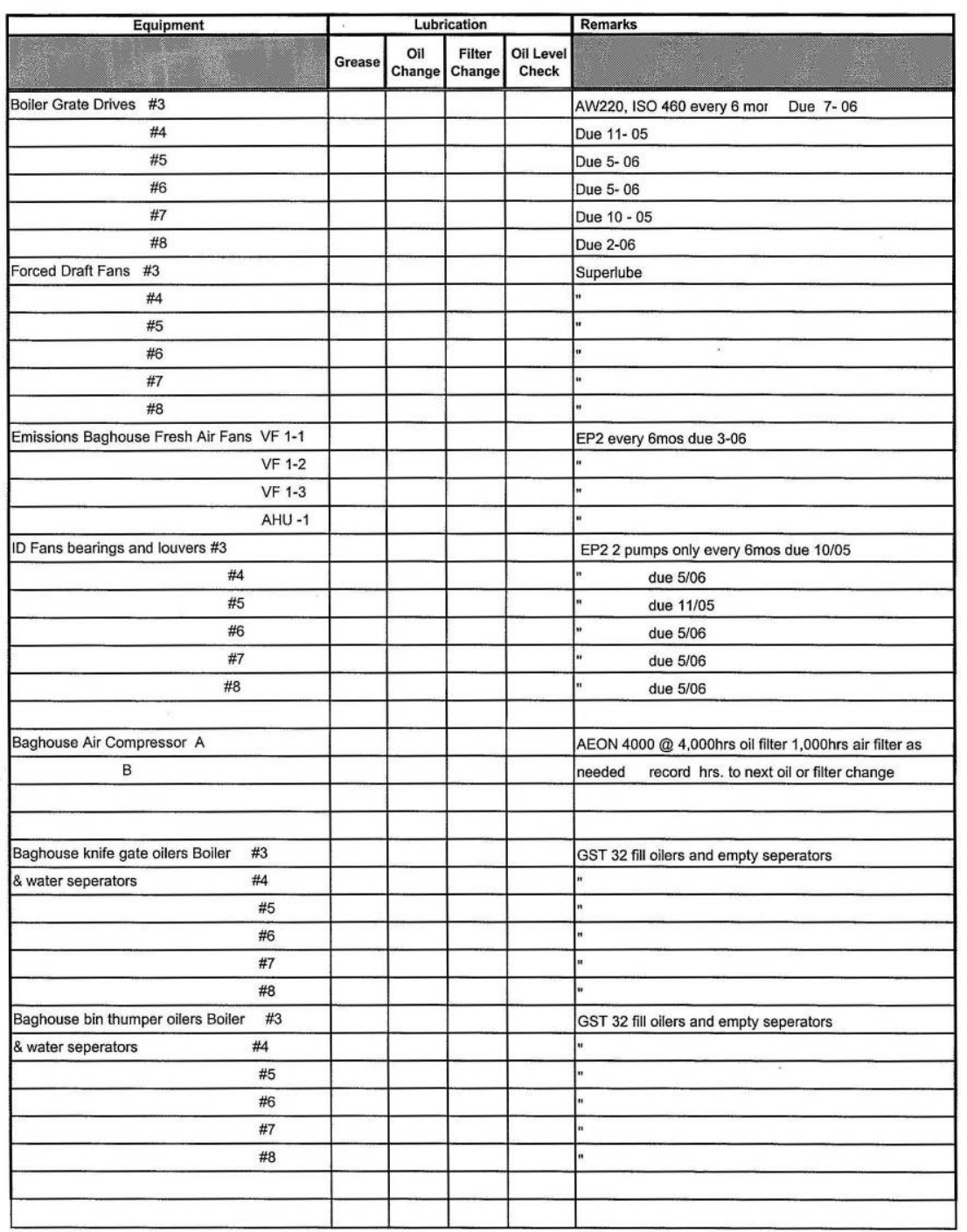

Figure B1. (cont'd). 


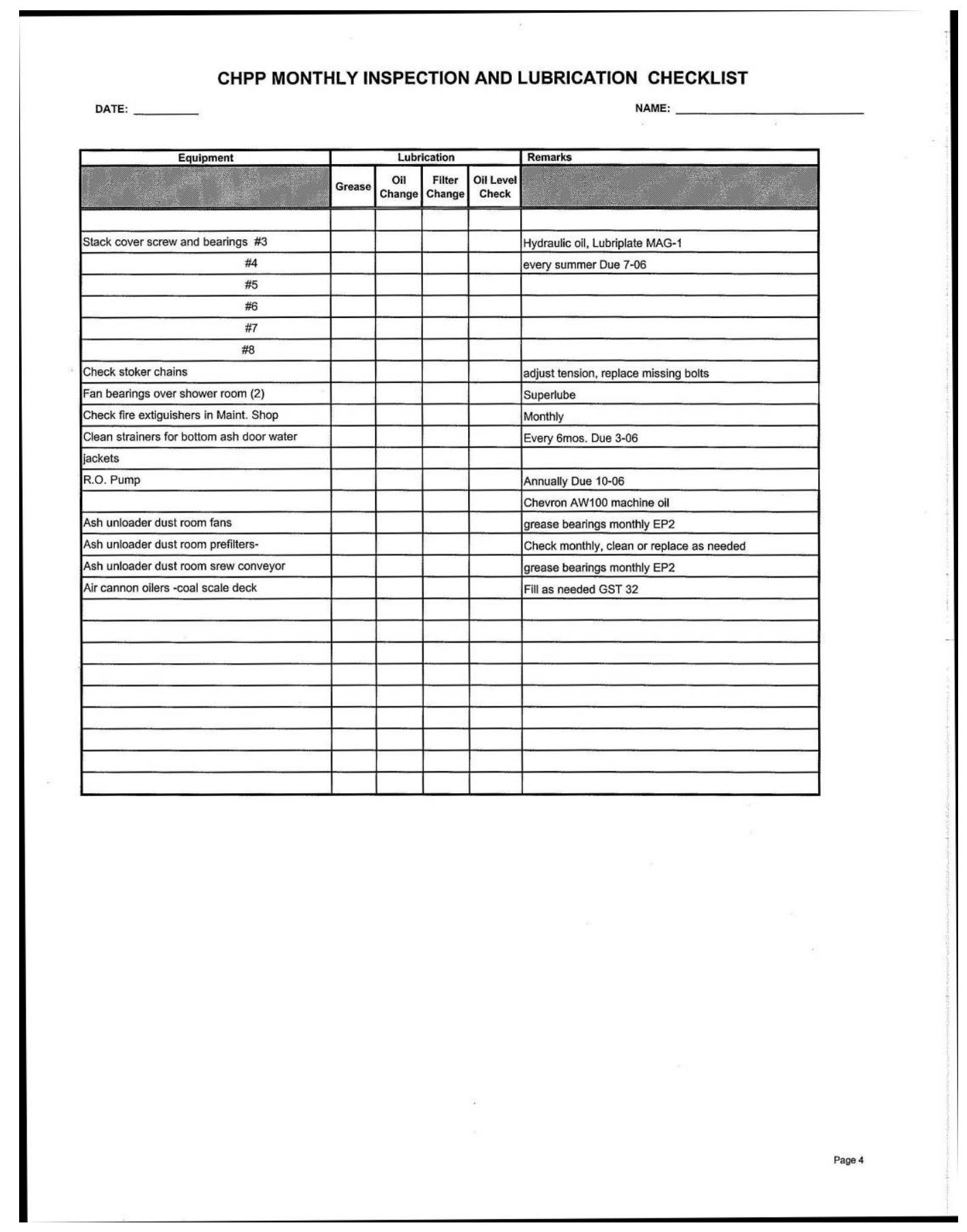

Figure B1. (cont'd). 


\title{
Appendix C: TM 5-650, Chapter 5, "Inspection and Preventative Maintenance"
}

TM 5-650

\author{
CHAPTER 5 \\ INSPECTION AND PREVENTIVE MAINTENANCE
}

\section{SECTION I. INTRODUCTION}

\section{5-1. PURPOSE AND SCOPE.}

This chapter is presented for the information and guidance of those responsible for maintenance of boiler plant equipment. It establishes a complete preventive maintenance system. The use of DA Form 4177, the Utilities Inspection and Service Record, is described. This system of maintenance assignments and records is sufficiently flexible to be applicable to most boiler plant installations. Although this manual schedules most of the maintenance called for by manufacturers, it is not intended to take the place of manufacturer's instruction sheets. Each plant must maintain for ready reference and use a manufactuerer's instruction file on all installed equipment.

\section{5-2. TYPES OF MAINTENANCE.}

a. Forced Maintenance. Forced outages for the repair or replacement of equipment parts that have failed in service can be, and often are, very costly. Through the application of proper operating procedures and careful inspection, it is possible to increase the length of time over which a boiler can be carried on the line before any repairs are required. This, in turn, will prolong the useful life of the equipment and minimize forced maintenance. The principal causes of forced outages and excessive maintenance are:

- Sustained and frequent overloading of fuel burning equipment

- Operating with improper air flow conditions

- Fouling of external heating surfaces

- Inadequate water conditioning

- Improper lubrication

Forced maintenance is outside the scope of this manual. Normally, forced maintenance and major overhauls are not performed by operating personnel, but rather by assigned maintenance personrel or outside contractors.

b. Preventive Maintenance. Preventive maintenance can be defined as the systemic and periodic inspection and servicing required to keep equipment in proper operating condition. It means ixing things before they break, thus keeping equipment in continuous service or ready for service. The life of boiler plant equipment depends liargely upon its maintenanc:, and the cost of operation in a welimaintained piant is consistently lower than in a pooriy ma:ntained one. In ac dition. proper preventive maintenance results in improved working conditions and better worker morale.

\section{5-3. RESPONSIBILITY}

The chief operator or plant supervisor has the ultimate responsibility for boiler plant equipment, its proper operation, and the scheduling and performance of preventive maintenance. The chief operator should assign to himself responsibility for all inspection and servicing required for plant safety. He will assign other operating or maintenance personnel the responsibility for maintenance of specific pieces of equipment, as required by the preventive maintenance record card system. Some items listed for daily inspection by an assigned individual also require hourly inspections by the operating personnel. These hourly inspections do not relieve the assigned operator of his responsibility to inspect, service, and record the equipment condition.

\section{5-4. INSPECTION.}

Inspection is the first step in a preventive maintenance program. The early detection of a problem can greatty reduce the amount of damage, simplify maintenance, and prolong equipment life. The key to effective inspection is a complete understanding of the equipment's operating characteristics. The operator should know the condition, sound, temperature, pressure, speed, vibration, and performance characteristics of each piece of equipment in the plant, and particularly those for which he is assigned responsibility. Any change in normal characteristics should be immediately reported, investigated, and corrected.

\section{5-5. HOUSEKEEPING.}

A neat boiler plant generally indicates a well run plant. The boiler plant should be kept free of all unnecessary material and equipment. Good housekeeping should be encouraged and procedures established to maintain the desired level of cleanliness. Equipment should be kept clean. Sometimes cleaning is all that is required to keep equipment in trouble-free operation. Mcisture, dirt, dust, cobwebs, bugs, and oil in the wrong piace are all enemies of mechinical and eiectricai equipment. Stop leaks as soon as they are detected. Unrepaired leaks at best represer: waste and at worst may cause extensive damage. 
$\operatorname{TM} 5-650$

\section{5-6. UTILITIES INSPECTION AND SERVICE RECORDS.}

Preventive maintenance programs are effective only if careful, accurate, and complete records are kept. In no other way can the Director of Engineering and Housing ensure that all personnel are carrying out their responsibilities and that equipment is being properly maintained. DA Form 4177, shown in figure 5-1, is the basic card from which the record system is assembled. Two separate cards, a field card and a master card, are made up for each major piece of plant equipment. A complete set of master c ards is kept in a loose-leaf binder in the plant office, which the field card becomes a written assignment of work for the operator. The record is complete within itself and is available for inspection by the Director of Engineering and Housing or Army command inspector. A copy of this manual should be kept in each plant to fa cilitate references to the items listed on the cards.

a. Record Card Entries. Care is required to initially fill in the cards properly. Each entry is discussed below.

(1) Equipment Number. The equipment number entry is made up of three parts separated by dashes. The first part is the boiler plant building number. The second part may refer to the paragraph in this chapter which discusses the equipment, or it may be a number assigned by the Director of Engineering and Housing, or an equipment classification code. The third part distinguishes between a number of identical or similar pieces of equipment.

(2) Description. Describe equipment briefly but in enough detail so that it can be readily identified.

(3) Preventive Maintenance To Be Done By. Show the job title and name of the person responsible for maintenance; this should normally be the person who actually operates the equipment. He is also responsible for reminding the chief operator, superintendent, or other supervisor of any special semiannual or annual inspections required, and for ensuring that the supervisor makes the appropriate entry on the card after the inspection is completed.

(4) Work To Be Done. Study this manual and the equipment manufacturers manual, noting all inspection and service required. Enter in this space the paragraph or subparagraph heading describing the operation. Add any operations not covered in the manual but needed to maintain the unit. Ensure that all necessary inspections and services are shown on the record card. List operations in order of frequency of performance, with daily service first.

(5) Item Number. Identify each operation with the proper item number. Usually the item number is the subparagraph number unless an item number is noted. Where the same item number is used to identify more than one operation, differentiate between them by adding a letter to one of the numbers; thus, if " ${ }^{n}$ " is used twice, write one of them as " $1 \mathrm{a}$ ".

(6) Reference. Insert paragraph numbers to facilitate reference to the appropriate manual.

(7) Frequency. Record frequency of operations, as shown in Time-Schedule columns. Modify suggested frequencies as required to fit local conditions.

(8) Time. Show specific day or month when service is due. Stagger quarterly semiannual, and annual inspections so as to minimize rush periods and schedule conflicts. Choose the season when the work can be best accomplished.

(9) Tab Index. Mark an $X$ at the top of the form alongside each month during which work is to be done or a report submitted. This helps to schedule operations, since overall work required in a given month can be quickly determined by reference to the tab index.

(10) Service Record. On the back of the card, record the date and item number whenever maintenance is performed, and initial. If service is required beyond the ability or authority of the inspector, he must request the proper help and enter the request in the Work Done column. For example, if inspection of a motor reveals a grooved commutator, the entry would read Electrician needed t complete Item 51 - commutator grooved. The work order number is entered under the column headed Signed and is initialed. When all spaces on the Service Record are filled in, a blank card should be stapled to the original.

b. Assignment of Work. Only general rules covering assignment of preventive maintenance work are given here. Actual assignments will necessarily depend upon the specific plant and the qualifications of operating personnel. Work loads of all personnel should be substantially equal, and duties assigned must be in keeping with the qualifications of the individual. A coal handler, for example, may inspect the stack and breeching for fly-ash accumulations, and examine guy wires, coal bunkers, elevators, and conveyors. He should not be expected to maintain and adjust flow meters or combustion controls.

(1) Chief Operator/Supervisor. The chief operator is charged with overall responsibility for the plant. Therefore, inspections having to do with safety of operation or the possibility of serious damage to equipment are assigned to him. These items must be checked at frequent intervals. Likewise, items of major importance such as internal inspection of boilers and furnaces should be under his personal supervision.

(2) Regulag Operators. Shift operators, firemen, or other qualified personnel usually have maintenance duties in addition to their regular assignments. The man to whom a given piece of equipment is assigned should perform the required maintenance during whatever shift he happens 
to be working on a given day. During this man's time off, the relief operator or the chief operator performs the scheduled maintenance. Maintenance activity can sometimes be assigned entirely to day-shift operators. This arrangement necessitates close supervision to guard against neglect, but maintenance work during daylight hours is more pleasant and frequently more effective.

(3) Maintenance Men. In plants where regular maintenance men are available, assignment of preventive maintenance work is simplified. Here day-shift work is usual. However, certain special items should still be assigned to skillful operators.

c. Record Card Example. Figure 5-1 illustrates a Master Record Card for a typical boiler. In this example the boiler is the No. 2 boiler located in building NN11. A Field Record Card would be similar, but would also include initials for all daily inspection and servicing performed.

d. Use of the Record Card System. The Record Card System consists of duplicate sets of the DA Form 4177 card, one set making up a Field File and the other the Master File. The Field File is made up of the forms forwarded to the operator who maintains the equipment. A copy of this manual is maintained in the plant to explain duties. The assigned operator makes all service entries and keeps his copies of the forms up to date. Forms in the Field File are kept in the operator's possession except at the beginning of the month, when they are sent to the supervisor for transfer of consolidated data to the Master File. Record cards in the Master File are arranged by equipment number and kept in the work supervisor's of fice. A movable tab is placed on the tab index of each card, above the month during which maintenance for the unit is next scheduled. When operators turn in the Field File at the beginning of the month, entries are checked to ensure that all work was done and a summary of the entries is transferred to the Master File. The summary includes any special difficulties encountered by the operator, work orders required for maintenance, and the consolidated entry of items checked. After all entries are made, movaable tabs are then shifted to the next month when maintenance is scheduled and Field File cards are returned to the operator. Any tabs in the Master File that are not moved are readily apparent. Since they indicate that a Field File card was not turned in or that work was not completed, immediate follow-up is essential. Careful supervision and attention to detail in setting up the system will pay dividends in accomplished maintenance and more efficient operation.

\section{5-7. TOOLS.}

Proper preventive maintenance requires proper tools and instruments. Review the operations listed on the maintenance cards and determine the tools required for each operation. There is no single list of tools which will apply to all plants. However, each plant should be equipped with a workbench with a pipe vise, a machinists vise, and a tool board.

a. Special Tools. Some maintenance operations require tools which would be used too infrequently to justify their purchase for the central boiler plant. If possible, such tools should be borrowed from other departments on the post; otherwise, requisition them. Indicate on the maintenance card the department from which they may be borrowed.

b. Care of Tools. Maintain all tolls in first-class condition. Take defective tools out of service immediately and repair or replace them. Use tools properly. If the proper tool for an operation is not available, immediate arrangements should be made for its procurement.

c. Tool Board. Keep all tools on a well-planned tool board or tool box, not in binx, benches, or drawers. Keeping tools on a tool board helps prevent loss and makes them instantly available when required. Locate the tool board in a conspicuous place, convenient to the majority of operators. Space should be provided on the board for additions to the tool supply. A board made of wood is especially sattisfactory since it is easily constructed and special hangers and brackekts required for the tools can easily be fastened to it. Steel tool boards are mor durable and are also frequently used. The shape or size of a tool should not prevent its being installed on the tool board. Extension cords, oil cans, flashlights, and electric drills can be installed on the board by use of special brackets. The outline of each tool should be painted on the board in a contrasting color to assist in replacing tools in their proper place and to serve as a ready check on missing tools.

\section{5-8. SPARE PARTS.}

Preventive maintenance requires an adequate stock of spare parts. Service conditions, the importance of the part to service continuity, and the ease of procurement all help to determine the kind and number of spare parts kept in stock. Examine the equipment requirements in the plant and prepare a spare parts inventory. Do not neglect to include small parts such as nuts, bolts, shear pins, steam traps, gaskets, valve seats, packing, and cotter pins.

\section{5-9. SPECIAL SUPPLIES.}

ubricants and cleaning solvents are needed for proper equipment operation and long life. Clean, properly lubricated equipment is required for successful plant operation.

a. Lubricants. Lubricants are frequently referred to in the Scheduled Preventive Maintenance section. Because of the extreme variations in equipment and service 
TM 5-650

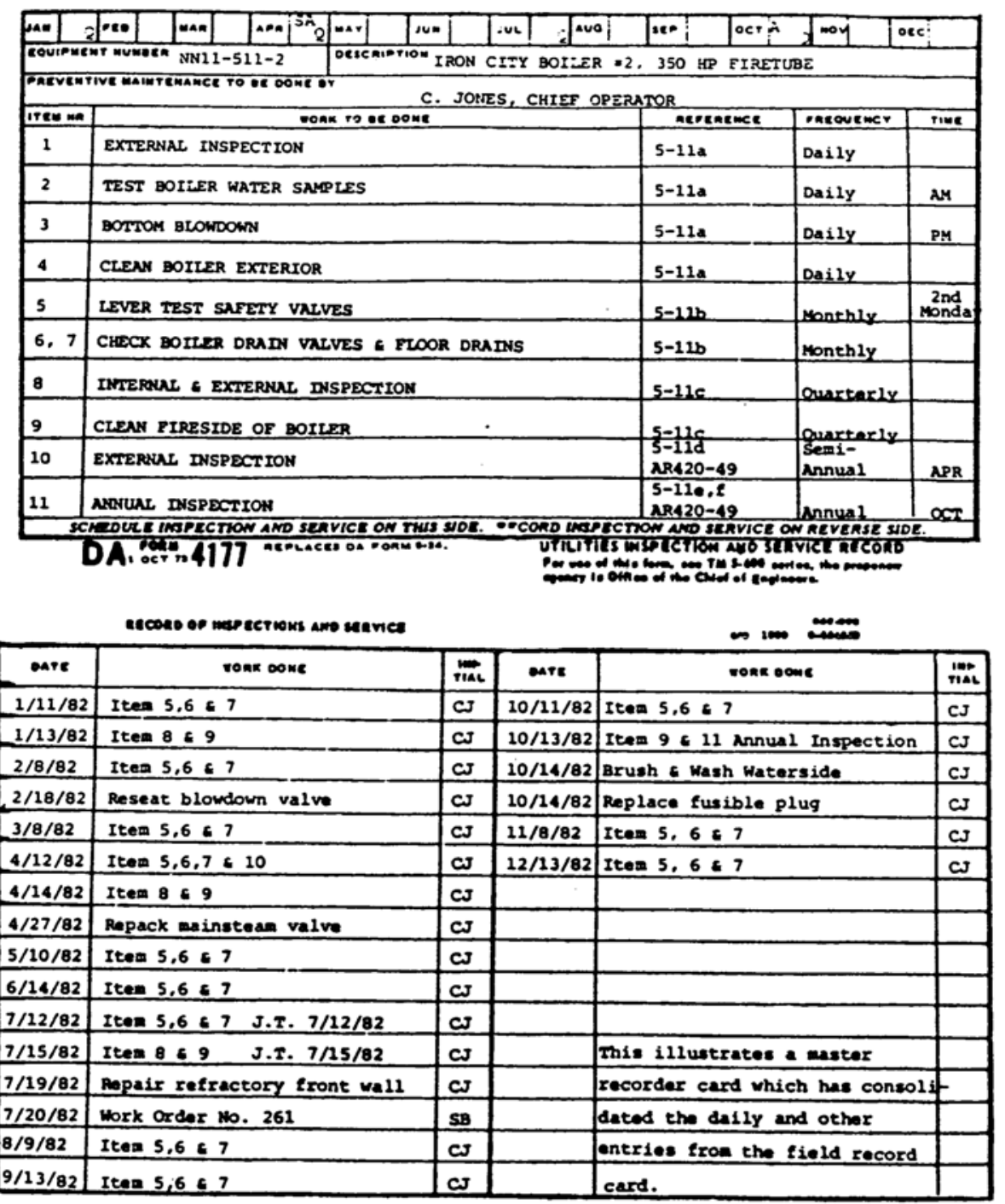

FIGURE 5-1. RECORD CARD EXAMPLE 
TM 5-650

conditions, the types of lubricants required for a given plant must be determined locally. The equipment manufacturers instructions, advice from lubricant manufactuerers, and advice of the Director of Engineering and Housing help to determine the lubricant requirements. Tables 5-1 and 5-2 are provided to list stock numbers and uses for standard Army lubricants.

b. Cleaning Solvents. Cleaning solvents such as mineral spirits, kerosene, and Varsol can be used in central boiler plants. Petroleum derivatives such as naphtha and gasoline present an explosion and fire danger and must never be used. Benzene especially must never be used, as it not only has a low flashpoint, but is also extremely toxic. Follow the precautions for use and storage that are provided with the solvents. When using cleanilng solvents, be sure the solvent is completely evaporated before placing the equipment back into service. When using solvents for cleaning electrical equipment, first remove all loose dirt and dust, then dip a rag into the solvent and wipe the insulation. When spraying solvents, extra precautions against fire or health hazards must be observed. When spraying solvents, extra precautions against fire or health hazards must be observed. When cleaning bearings or machined parts, place the cleaned parts on clean rags or paper, allow them to dry and immediately dip them in oil or apply lubricant. Do not allow rust-susceptible parts tơ remain exposed to air after cleaning.

\section{SECTION II. SCHEZDULED PREVENTIVE MAINTENANCE}

\section{5-10. SCHEDULING AND USE OF THE INFORMATION.}

The following sections provide suggested preventive maintenance schedules for many types of central boiler plant equipment. The subparagraph designates the frequency for preventive maintenance: daily, weekly, monthly, quarterly, semiannually, and annually. The second subparagraph numbers are numbered consecutively and can be used as index numbers on the record cards. The lists of inspection and work presented here should not be considered to be complete. Review the manufacturers operating and maintenance instructions and add additional required items. Review the applicable ASME Code and the National Board Inspection Code published by the National Board of Boiler and Pressure Vessel Inspectors, 1055 Crupper Avenue, Columbus, Ohio 43229, for additional requirements and suggestions. Other equipment will be found which is not discussed in this section. Such equipment should be researched with the manufacturer and appropriate record cards prepared. The frequency suggested here is based on good practice. Modify the suggested frequency to best match local conditions and experience.

\section{5-11. BOILERS.}

The successful operation and maintenance of a boiler is greatly dependent on the operation and maintenance of its auxiliaries. Boiler operation and boiler preventive maintenance both involve the inspection of the boiler operating conditions.

a. Daily

(1) Check the following conditions and take action as required (a) Water level.

(b) Steam pressure or water temperature stability.

(c) Flue gas temperature at two loads, compared to clean boiler temperatures.

(d) Flue gas oxygen or carbon dioxide levels at two loads, compared with baseline data.

(e) Water or steam leaks.

(f) Air leaks in casing, ducts, or setting.

(2) Take water samples and perform necessary tests per chapter 4. Adjust internal treatment and continuous blowdown.

(3) Blow down steam boilers through the bottom blowdown connection to remove sludge.

(4) Clean boiler exterior.

b. Monthly.

(1) Item 5. Lever test all safety valves. Reference paragraph 5-15.

(2) Item 6. Check all boiler drain valves for proper opening and closing.

(3) Item 7. Check boiler room floor drains for proper function.

c. Quarterly. One of the quarterly inspections should be timed to coincide with the annual inspection by the Authorized Inspector.

(1) Item 8 . Internally and externally inspect the boiler. Reference semi-annual and annual procedues.

(2) Item 9. Clean the fireside of the boiler.

d. Semi-Annually. Semi-annually or as required by AR 420-49 an external inspection of the boiler by an Authorized Inspector is required. Item 10 . With the boiler operating, inspect for the following:

(1) Any evidence of steam or water leakage.

(2) Pressure gage accuracy and function.

(3) Safety or safety relief valves. 
TM 5-650

Table 5-1. Lubricating Oils, Greases, and Preservatives

\begin{tabular}{|c|c|c|c|c|c|}
\hline Product & $\begin{array}{l}\text { Military } \\
\text { Specification } \\
\text { Number }\end{array}$ & Symbol & $\begin{array}{l}\text { Approximate } \\
\text { SAE } \\
\text { Grade(1) }\end{array}$ & $\begin{array}{l}\text { National } \\
\text { Stock } \\
\text { Number(2) }\end{array}$ & $\begin{array}{l}\text { Temperature } \\
\text { Above }\end{array}$ \\
\hline Lubricating oil, general purpose & MIL-L-15016A & $\begin{array}{l}2075 \\
2110(3) \\
2135 \\
2190 \\
2250 \\
3050(3) \\
3065 \\
3080 \\
3150\end{array}$ & $\begin{array}{l}20 \mathrm{~W} \\
10 \mathrm{~W}-75 \mathrm{~W} \\
20 \mathrm{~W}-75 \mathrm{~W} \\
30 \mathrm{~W} \\
40 \mathrm{~W} \\
20 \mathrm{~W} \\
30 \mathrm{~W}-80 \mathrm{~W} \\
40 \mathrm{~W} \cdot 90 \mathrm{~W} \\
140 \mathrm{~W}\end{array}$ & $\begin{array}{r}9150-00-223-4137 \\
9150-00-231-6664 \\
9150-00-231-6639 \\
9150-00-223-4138 \\
9150-00-223-8890 \\
9150-00-240-2258\end{array}$ & $\begin{array}{r}-10^{\circ} \mathrm{F} \\
0^{\circ} \mathrm{F} \\
0^{\circ} \mathrm{F} \\
35^{\circ} \mathrm{F} \\
35^{\circ} \mathrm{F} \\
0^{\circ} \mathrm{F} \\
5^{\circ} \mathrm{F} \\
15^{\circ} \mathrm{F} \\
25^{\circ} \mathrm{F}\end{array}$ \\
\hline Lubricating oil, compounded & MIL-L-15019B & $\begin{array}{l}4065 \\
6135 \\
8190\end{array}$ & $\begin{array}{l}40 \mathrm{~W} \\
140 \mathrm{~W} \\
30 \mathrm{~W}\end{array}$ & $\begin{array}{l}9150-00-243-3196 \\
9150-00-231-6645 \\
9150-00-231-9033\end{array}$ & $\begin{array}{l}35^{\circ} \mathrm{F} \\
60^{\circ} \mathrm{F} \\
35^{\circ} \mathrm{F}\end{array}$ \\
\hline Lubicating oil, mineral, cylinder & MIL-L-15018B & 5190 & $140 \mathrm{~W}$ & $9150-00-240-2260$ & $60^{\circ} \mathrm{F}$ \\
\hline $\begin{array}{l}\text { Lubicating oil, steam turbine } \\
\text { (noncorrosive) }\end{array}$ & MIL-L-17331B & 2190TEP & $30 \mathrm{~W}$ & $9150-00-235-9061$ & $60^{\circ} \mathrm{F}$ \\
\hline $\begin{array}{l}\text { Lubricating oil, internal } \\
\text { combustion engine, subzero }\end{array}$ & MIL-L-10295A & OES & & $9150-00-242-7603$ & $-65^{\circ}$ to $0^{\circ} \mathrm{F}$ \\
\hline $\begin{array}{l}\text { Lubricating oil, instrument } \\
\text { jewel-bearing, nonspreading } \\
\text { low temperature }\end{array}$ & MIL-L-3918 & ocw & & $9150-00-2270-0063$ & $-40^{\circ} \mathrm{F}$ \\
\hline $\begin{array}{l}\text { Lubricants; chain, exposed-gear } \\
\text { and wire rope }\end{array}$ & VV-L-751A & CW-11B & & $9150-00-246-3276$ & All \\
\hline $\begin{array}{l}\text { Lubricating oil, internal } \\
\text { combustion engine }\end{array}$ & MIL-L-2104A & $\begin{array}{l}\text { OE-10 } \\
\text { OE-30 } \\
\text { OE-50 }\end{array}$ & $\begin{array}{l}10 \mathrm{~W} \\
30 \mathrm{~W} \\
50 \mathrm{~W}\end{array}$ & $\begin{array}{l}9150-00-265-9425 \\
9150-00-265-9433 \\
9150-00-265-9440\end{array}$ & $\begin{aligned} 20^{\circ} \mathrm{F} \\
0^{\circ} \mathrm{F} \\
15^{\circ} \mathrm{F}\end{aligned}$ \\
\hline Grease, automotive and artillery & MIL-G-10924A & GAA & & $9150-00-190-0907$ & $-65^{\circ}$ to $125^{\circ} \mathrm{F}$ \\
\hline Grease, ball and roller bearing & MIL-G-18709 & BR & & $9150-00-249-0908$ & $125^{\circ}$ to $200^{\circ} \mathrm{F}$ \\
\hline Grease, graphite & VV-G-471C & GG-1 & & $9150-00-272-7652$ & $125^{\circ} \max$ \\
\hline $\begin{array}{l}\text { Lubricating oil, internal } \\
\text { combustion, preservative }\end{array}$ & MIL-L-21260 & PE-1 & & $\begin{array}{l}9150-00-111-02-1 \\
9150-00-111-0208\end{array}$ & \\
\hline $\begin{array}{l}\text { Lubricating oil, preservative, } \\
\text { medium }\end{array}$ & PL-MED & & & $9150-00-231-2356$ & \\
\hline $\begin{array}{l}\text { Corrosive preventive, } \\
\text { petroleum, hot application }\end{array}$ & MIL-G-11796A & CL-3 & & $8030-00-231-2353$ & \\
\hline $\begin{array}{l}\text { Corrosion preventive, } \\
\text { compound, solvent cutback, } \\
\text { cold application }\end{array}$ & MIL-C-16173B & CT-1 & & $8030-00-231-2362$ & \\
\hline
\end{tabular}

NOTES

(1) $\mathrm{SAE}$ numbers $10 \mathrm{~W}$ through $50 \mathrm{~W}$ are for crankcase lubrication. SAE numbers $75 \mathrm{~W}$ through $140 \mathrm{~W}$ are for transmission lubrication.

(2) National stock numbers are for 5-gallon containers for lubricating oils and 35-pound containers for grease, except 1/2-ounce can for MIL-L-3918. For other containers, see Federal Supply Catalog.

(3) Quenched. 
TM 5-650

Table 5-2. Lubricating Oil and Grease Uses

\begin{tabular}{|c|c|c|c|}
\hline Equipment & $\begin{array}{l}\text { Oil or } \\
\text { Grease Symbol }\end{array}$ & Equipment & $\begin{array}{l}\text { Oil or } \\
\text { Grease Symbol }\end{array}$ \\
\hline 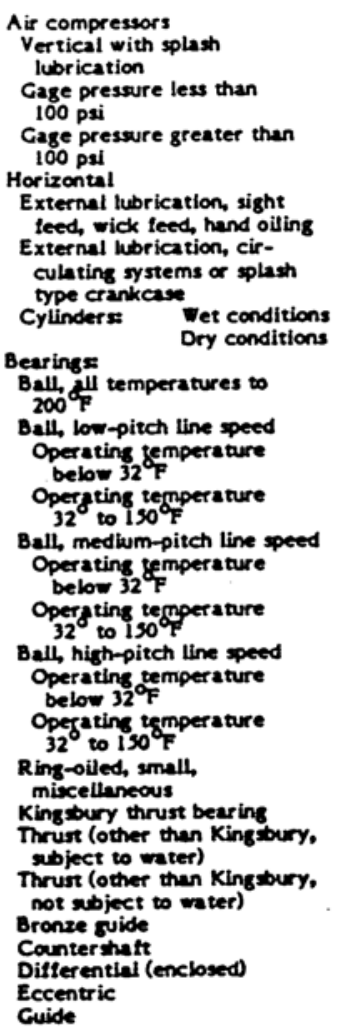 & 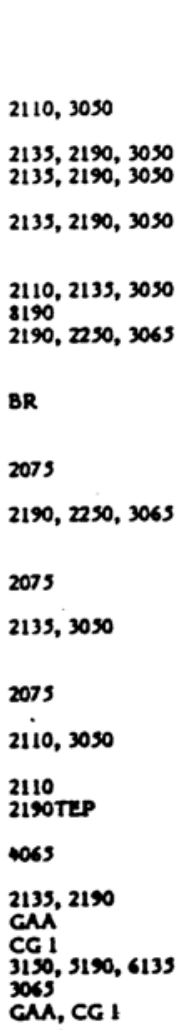 & $\begin{array}{l}\text { Oilite bronze bushings } \\
\text { Pillow block } \\
\text { Underwater-baboitted } \\
\text { Universal joint, slip splines } \\
\text { Chain Drives } \\
\text { Roller } \\
\text { Roller (enclosed) } \\
\text { Roller (semienclosed) } \\
\text { Slow-speed } \\
\text { Medium-speed } \\
\text { Chemical feeders } \\
\text { Clarifier equipment } \\
\text { Coupllngss } \\
\text { Drive jaw clutch } \\
\text { Gear case or gear head } \\
\text { Gears } \\
\text { Herr ingtone } \\
\text { Hellal } \\
\text { Motor reducers } \\
\text { Open } \\
\text { Planetary } \\
\text { Dorm and pump transmiasion } \\
\text { Instruments } \\
\text { Motors }\end{array}$ & 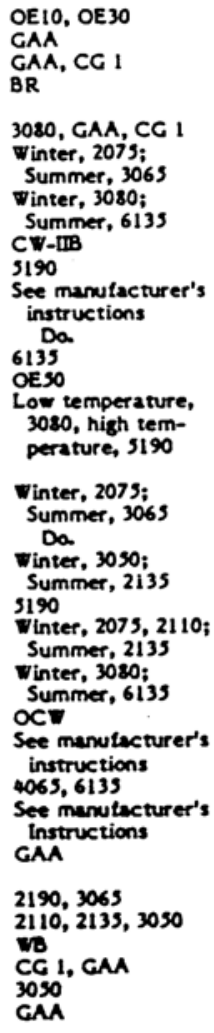 \\
\hline
\end{tabular}


TM 5-650

(4) Water level gage function.

(5) Pressure controls function.

(6) Low water fuel cutoff and level control function.

(7) Steam, water, and blowdown piping for leakage, vibration, proper rating, and freedom to expand.

(8) Review the boiler log, maintenance records, and water treatment records to ensure that regular and adequate tests have been made.

e. Annually. Annual inspections are required by AR 420-49. Boiler inspections are to be made in accordance with Rules for Inspections in Section VII of the ASME Boiler and Pressure Vessel Code. An Authorized Inspector is required. Preparation for an annual inspection is discussed in the next subparagraph. The most recent copy of Boiler Inspection Report, DA Form 416, must be posted for each boiler in the plant.

(1) Item 11. Inspect the boiler for the following; clean and repair as required:

(a) Water side of tubes for deposits caused by water treatment, scale, or oil. Remove excessive deposits by mechanical or chemical means.

(b) Stays and stay bolts. Repair or replace as required.

(c) Water side of tubes and boiler for corrosion, grooving, and cracks.

(d) All manholes, internals, and connections to the boiler for cracks, corrosion, erosion and clean passages.

(e) Fusible plugs. Replace annually.

(f) Tube sheets, tube ends and drums for signs of thinning, leaking, corrosion, or cracks. expansion.

(g) Boiler supports and setting for freedom of

(h) Fire side of tubes for bulging, blistering, leaks, corrosion or erosion.

(i) Setting for cracks, settlemlent, loose bricks, spallilng, and leakage.

(j) Safety valves and their connections and piping. Test the safety valves.

(k) Baffles.

(I) Blowdown piping.

(m) Boiler appliances.

(n) When required by the Authorized Inspector, hydrostatically test the boiler. records.

(o) Review past inspection reports and plant

(p) Make any other inspection required by the ASME Code or National Board Inspection Code.

(2) Preparation for an Annual Inspection. Make the following preparations for annual inspection. Other preparations may also be required by the ASME or National Board Inspection Codes.

(a) Where sootblowers are installed, blow soot before reducing boiler load below 50 percent. (b) Shut down the boiler per paragraph 3-33. Shut off fuel supply lines and lock when possible. Sufficiently cool the boiler before draining the water. Internally wash the boiler to remove sludge deposits, suspended solids sediment, and loose scale. Do not clean drums or tubes until after the inspection unless prior agreement has been reached with the Authorized Inspector.

(c) Before opening or entering any part of the boiler ensure that the nonreturn and stcp valves are closed, tagged, and preferably padlocked and drain valves between the two are opened. The feed and check valves must be closed, tagged, and padlocked and drain valves between the two must be opened. After draining the boiler blowoff valves must be closed and padlocked. All drain and vent lines should be opened.

(d) Proper low voltage lighting should be provided for internal inspection.

(e) The fire side walls, baffles, and tubes should be thoroughly swept and ash and soot removed.

(f) If the installation burns coal, remove the grate bars, and clean the firebox plates along the grate line until the bare metal is exposed. Take care not to damage the metal during the cleaning.

(g) Have available a supply of gaskets for manholes and handholes, and suitable wrenches for removing and replacing covers.

(h) Replace fusible plugs.

(i) If insulation conceals manufactuerers inscribed data, remove the lagging and clean the surface carefully so that die-cut letters and figures can be easily read.

(j) Assign a qualified boiler plant operator to assist the Inspector throughout the tests.

(k) Be prepared to run a hydrostatic pressure test. A hand pump should be provided for this test if required. Provide gags to prevent safety valves from lifting when test pressure is applied. If hydrostatic pressure tests on more than one boiler are contemplated, sufficient gags should be provided for all the boilers. If boiler gages and controls are not designed for the proposed test pressure, be prepared to isolate or remove them and plug the openings.

(1) Have boiler records available.

f. Taking a Boiler Out of Servicf. Whenever a boiler is to be out of service for more than 'wo days, thoroughly clean the fire side of the boiler, flues, economizer and air heater. Ash and soot deposits must he removed. Dry ash and soot are not corrosive but moisture in combination with the ash and soot of sulfur bearing fuel is. To avoid acid attack and corrosion of the metal, ash and soot must be removed.

\section{5-12. ECONOMIZERS}


Reference paragraph 2-7.

a. Daily: Inspect for leaks in piping, valves, packings, gasketed joints, handhole openings, casing, etc. Make repairs as required.

b. Monthly. Check the following under identical load conditions:

(1) Item 2. Water pressure drop through the economizer.

(2) Item 3. Draft losses across the economizer.

(3) Item 4. Gas temperature drop across the economizer. An increase in draft loss and a decrease in gas temperature drop normally indicates a fouling condition.

c. Annually. During the annual boiler overhaul, clean and inspect the economizer. AR 420-49 and ASME Boiler and Pressure Vessel Code requires inspection of the economizer in addition to the boiler.

(1) Item 5. Externally look for signs of overheating, leakage, wear, or corrosion in pressure parts. Check the baffles and tubes in the area of sootblowers for signs of abrasion caused by fly ash or steam cutting. Check the elements of the sootblower.

(2) Item 6. Internally look for corrosion, erosion, scale, sludge deposits, or oil in tubes and headers.

\section{5-13. AIR HEATERS.}

Reference paragraph 2-8.

a. Daily.

(1) Inspect the air heater for gas or air leaks in duct, casing, gasketed joints, etc.

(2) Inspect for abnormal air or gas temperatures.

(3) Inspect for mechanical drive problems on rotary air heaters, if supplied.

(4) Establish a lubrication schedule for rotary air heaters in accordance with the manufacturers recommendations.

b. Monthly: Item 5. Check the following under idential load conditions:

(1) Air and gas side draft losses.

(2) Gas temperature drop through the air heater.

(3) Inspect for mechanical drive problems on rotary air heaters, if supplied.

(4) Establish a lubrication schedule for rotary air heaters in accordance with the manufacturers recommendations.

b. Monthly: Item 5. Check the following under identical load conditions:

(1) Air and gas side draft losses.

(2) Gas temperature drop through the air heater.

(3) Air temperature rise through the air heater. An increase in gas side draft losses combined with a decrease in air temperature rise indicates excessive soot deposits in the tubes or gas passages.

(4) Make an orsat or oxygen analysis of the flue gas at the air heater inlet and outlet. The difference in total air content between the analyses indicates air leakage. Repair if leakage is excessive.

c. Annually.

(1) Item 6. During the boiler overhaul, clean and inspect the air heater. Look for indications of corrosion, erosion, leakage, and wear.

(2) Item 7. In rotary regenerative air heaters, inspect the motor drive, speed reducer, auxiliary air motor if provided, lubricating system, cooling system, bearings, rotor seals, etc.

(3) Item 8. Check the condition of sootblowers and washing equipment.

\section{5-14. WATER COLUMNS.}

Reference paragraph 2-11.

a. Daily.

(1) Blow down and inspect all water columns, gage glasses, level indicators, and level alarm devices for leaks, correct operation, correct level indication, and adequate lighting. Repair leaks immediately.

(2) Check to see that valves between boiler and gage glass are free and operational.

(3) When provided, test high and low automatic alarm to ensure that it is in perfect order. Repair when faulty

b. Annually: Item 4. During annual boiler overhaul, or more often if necessary, dismantle, clean, and inspect all parts such as valves, alarm linkages, floats, chains, alarms, glasses, diaphragms, or electrodes. Replace or repair damaged or worn parts are required to ensure proper functioning.

\section{5-15. SAFETY VALVES.}

Reference paragraph 2-13.

a. Daily.

(1) Check for steam leakage indicating damaged seat, defective parts or lodged scale. Correct immediately such faults as leaking, simmering or chattering.

(2) Check supports and anchors of discharge pipe.

(3) Check the drain line from safety valve outlet to ensure that it is open and will function when needed.

b. Monthly: Item 4 . Check each safety valve by raising the valve off the seat by listing the lever. Keep the valve wide open for at least 10 seconds to blow dirt and scale clean from the seat. Close the valve by suddenly releasing the lever.

c. Annually: Item 5. Before and after the annual steam generator inspection and overhaul, test the operation of all safety valves. Testing is also required whenever the spring or blow back ring has been reset or adjusted. 
TM 5-650

\section{5-16. FUSIBLE PLUGS.}

Reference paragraph 2-16. These items should be put on the boiler record card where applicable.

a. Quarterly: Inspect fusible plugs during boiler inspections. Scrape the surface clean and bright. Replace if the metal does not appear sound.

b. Annually: Item 2. Replace fusible plugs at least once a year.

\section{5-17. SOOTBLOWERS.}

Reference paragraph 2-17b.

a. Daily.

(I) Check for leaks. Repair if required.

(2) Check for correct operation of the system components.

b. Semi-Annually.

(l) Item 3. During the boiler outages, inspect the following items and repair if required:

(a) Defective elements (warped, corroded, eroded, or otherwise damaged).

(b) Worn, loose, or defective nozzles. (c) Incorrect blowing and adjustment.

(d) Incorrect location of elements or nozzles. bearings.

(e) Alignment and tightness of the supporting

(f) Defective chains, control valves, and control system components.

(g) Condition of sootblower piping system. of the jet.

(h) Evidence of abrasion caused by impingement leakage.

(2) Item 4. Repack and adjust glands to prevent

\section{5-18. STOKERS.}

Reference paragraph 2-18.

a. Daily.

(1) Clean exposed parts of the stoker.

(2) Inspect all accessible parts. Pay special attention to bolts and connections in shear pins or safety release mechanisms. Be sure there is no binding which may keep the protective devices from functioning. Operating personnel should inspect the following items hourly:

(a) Hot bearings.

(b) Foreign material in coal.

(c) Mechanical linkages.

(d) Damaged, overheated, or burned out parts.

(e) Oil leaks. systems.

(f) Proper oil level and condition of hydraulic

(g) Correct oil pressures and oil temperature.

(h) Clinkers.
(3) Establish lubrication requirements and a schedule in accordance with the manufacturers requirements.

b. Quarterly. Make the following general inspection and overhaul whenever a boiler is removed from service.

(1) Item 4. Inspect the complete stoker. Check for wear on surfaces of feeder-box sides, conveyor areas, and all moving parts. Check alignment and condition of the grates. Replace broken, warped, or distorted parts promptly. Check the following:

(a) Clearances between grate elements.

(b) Tightness of all nuts, bolts, and holding parts.

(c) Drive mechanism and drive unit. Clean and repair any damage to gears and other components.

(d) Bearings of drive unit. Lubricate as required.

(e) Electrical controls and connections.

(f) Fan and its bearings. Check and lubricate bearings.

(g) Fly-ash reinjection system. Look for worn areas and plugged lines. Repair if required.

(h) Air seals. Repair if required.

(2) Item 5. Remove slag from furnace walls adjacent to stoker or fuel-bed surface. Take care to avoid injury to the brickwork.

\section{5-19. PULVERIZED COAL EQUIPMENT.}

Preventive maintenance procedures for pulverized coal equipment may be found in manufacturers instructions and Navy Manual MO-205.

\section{5-20. COAL HANDLING EQUIPMENT.}

Reference paragraph 2-19.

a. Daily.

(1) Inspect for the following hourly:

(a) Unusual noise or vibration.

(b) Motor overheating.

(c) Hot bearings.

(d) Coal accumulation. Clean as required.

(e) Correct chain or belt tension.

(f) Damaged or loose drag flights or buckets.

(g) Damaged chain, chain sprockets, or belts.

(h) Proper operating conditions.

(i) Oil or water leaks. Repair as required.

(j) Proper lubricant levels.

(2) Establish lubrication requirements and schedule as required by manufacturers instructions.

(3) Inspect scales for zero load balance.

b. Monthly: Item 4. Inspect for the following:

(1) Gear boxes, sheaves, rollers, shafts for proper lubrication, freedom of movement and bearing play.

(2) Screens for holes or plugging. Repair or clean as required.

(3) Structural frame for broken or bent parts and 
loose or damaged joints.

(4) Proper alignment of pulleys and other parts.

(5) Proper operation of control and safety devices. c. Semi-Annually: Item 5. Inspect for the following:

(1) Corrosion or erosion of hoppers, chutes, and gates.

(2) Lining and protective coatings for damage.

(3) Scale levers, knife edges, and bearings for wear or damage. Repair or replace as required.

(4) Concrete structures for cracks or other damage.

d. Annually: Item 6. Prepare applicable metal surfaces and repaint.

\section{5-21. ASH HANDLING EQUIPMENT.}

Reference paragraph 2-20.

a. Daily.

(1) Inspect for the following:

(a) Piping leaks. Repair immediately.

(b) Proper operation of steam or mechanical exhauster.

(c) Proper operation of air wsher, if provided. grinders.

(d) Proper operation of ash gates and clinker

(e) Proper operation of automatic steam valves and automatic controls, ilncluding maintenance of correct steam pressue.

b. Quarterly.

(1) Item 2. Inspect conveyor piping, especially at elbows, for accumulated ash and erosion. Rotate, repair, or replace as necessary.

(2) Item 3. Inspect steam exhauster for corrosion and erosion.

(3) Item 4. Inspect wsher internals for wear, ash accumulation, and nozzle condition. Clean and repair as necessary.

\section{5-22. OIL BURNERS.}

Reference paragraphs 2-21 and 3-18.

a. Daily.

(1) Inspect for the following hourly:

(a) Oil, steam, or air leaks. Repair immediately.

(b) Unburned oil deposits and overheating of burner parts.

(c) Burner flame for proper shape, color and stability.

(d) Proper operating pressures and temperatures.

(2) Remove and clean the oil atomizer.

(3) Clean burner exterior.

(4) Follow the established schedule for cleaning burner strainers.

b. Annually.

(1) Item 5. Completely remove and clean the burner and igniter.
(2) Item 6. Inspect all air register and burner parts for freedom of movement, warpage and wear. Repair or replace as required. Adjust all parts for proper operation. The services of a burner servicemen may be required.

(3) Item 7. Replace atomizer tips or nozzles that have been in normal service with new tips or nozzles.

(4) Item 8. Calibrate burner pressue and temperature gages.

\section{5-23. OIL HANDLING EQUIPMENT.}

Reference paragraphs 2-22 and 3-18.

a. Daily.

(1) Inspect for the following:

(a) Oil, steam water, or air leaks. Repair immediately. (b) Proper operation of traps, controls, and instrumentation levels.

(c) Proper operating pressures, temperatures, and

(2) Clean equipment as required.

(3) Establish a schedule for cleaning strainers.

(4) Inspect and maintain pumps as outlined in paragraphs 5-34, 5-35, and 5-36.

b. Annually.

(1) Item 5. Inspect and clean heaters and tanks internally and externally. Inspect carefully for corrosion, erosion, pitting, plugged tubes, damaged baffles, sludge deposits, water accumulations, and scale deposits.

(2) Item 6. Inspect for damage to protective coatings or paint. Repair or repaint as required.

(3) Item 7. Test relief valve settings and operation.

(4) Item 8. Clean, inspect, and calibrate all controls and instrumentation.

\section{5-24. GAS BURNERS.}

Reference paragraphs 2-23 and 3-19.

a. Daily. Inspect for the following hourly:

(1) Gas or air leaks. Repair immediately.

(2) Proper gas and air pressures.

(3) Burner flame for proper shape, color, and stability.

(4) Overheating or binding of burner parts.

b. Annually.

(l) Item 2. Completely remove and clean the burner and igniter.

(2) Item 3. Inspect all burner parts for freedom of movement, warpage, and wear. Inspect gas nozzles. Repair or replace as required. Adjust all parts for proper operation. The services of a burner serviceman may be required.

(3) Item 4. Calibrate burner pressure gages.

\section{5-25.} CONTROLS.

Reference paragraph 2-25. a. Daily.

(1) Inspect :or water leaks. Repair immediately. 
TM 5-650

(2) Observe operation of all control devices. Report and repair any malfunction immediately.

(3) Establish a lubrication schedule for all componurts in the control system in accordance with manufacturers recommendations.

b. Annually.

(i) Item 4. During the boiler overhaul, or more often if necessary, clean and inspect all control components. Look for signs of corrosion, erosion, or wear and for deposits, leaks, and defective parts. Repair as required.

(2) Item 5. Check settings, adjustments, and operation of all components.

\section{5-26. COMBUSTION CONTROLS.}

Reference paragraphs 2-26 ard 3-20.

a. Daily.

(1) Inspect for air, oil, gas and water leaks. Repair immediately.

(2) Blow down compressed air drip legs and filters.

(3) Check jackshafts, dampers and linkages for slippage and freedom of movement.

(4) Inspect for stable and proper operation.

(5) Clean exterior of controls.

(6) Establish lubrication requirements and schedule in accordance with the manufacturers instructions.

b. Monthly: Item 7. Replace or clean all system filters. c. Annually.

(1) Item 8. Inspect and completely clean all control devices internally. Replace any worn, corroded, or damaged parts.

(2) Item 9. Test for correct calibration. Adjust as required.

(3) Item 10. Test control settings under operating conditions. Optimize control function to improve plant efficiency.

(4) Item 11. Obtain the assistance of a fully trained combustion control service engineer as required to calibrate, clean and adjust the controls.

\section{5-27. BOILER SAFETY CONTROLS.}

Reference paragraphs 2-27 and 3-21.

a. Daily.

(1) Inspect all safety controls for leaks and cleanliness. Repair and clean immediately.

(2) Blow down the water column, gage glass, and low water fuel cutoff each shift. Test function.

b. Monthly.

(1) Item 3. Inspect all safety controls for such problems as dirty switch contacts, defective diaphragms or sensing elements, loose wires, dirty flame scanner lens or flame rod. Clean or repair immediately.

(2) Item 4. Test all safety controls for proper calibration aud operation.

\section{5-28. INSTRUMENTATION.}

Reference paragraph 2-28.

a. Daily.

(1) Inspect for leaks. Repair immediately.

(2) Check for proper operation. Report any malfunction. Only trained personnel should place in service, remove from service, calibrate, or maintain instruments.

(3) Inspect for undue vibration, broken glass, lighting, and readability.

b. Annually. Once a year, or more often if necessary, make a thorough inspection of all instruments and gages for corrosion, deposits, or other defects. Item 4. Inspect carefully for the following:

(1) Ruptured or distorted pressue parts.

(2) Incorrect calibrations or adjustments.

(3) Badly worn pins or bushings.

(4) Damaged or burned thermocouple wire insulation.

(5) Leaking or damaged diaphragms, bellows, and gaskets.

(6) Mercury separations in thermometers.

(7) Loose pointers.

(8) Broken balance-arm screws.

(9) Plugged piping or tubing.

(10) Broken or damaged adjustment assemblies.

(11) Defective clockwork mechanism or electric motor operation.

\section{5-29. MECHANICAL COLLECTORS.}

Reference paragraph 2-32.

a. Daily.

(1) Observe draft gage readings and compare with normal readings for that cperating condition.

(2) Check dust level in hopper to ensure hoppers are being emptied on a regular basis.

b. Quarterly. At the time of boiler outage, inspect for the following:

(1) Item 3. Check all gasketed joints for leaks. Replace damaged or defective gaskets as required.

(2) Item 4. Check the interior of dust collector for caked deposits, corrosion, erosion, loose parts, and other damage. Clean and repair as required.

(3) Item 5. Check the exterior of dust collector for damaged parts, paint, corrosion, etc. Clean and repair as required.

c. Annually: Item 6. Paint the entire assembly.

\section{5-30. STACKS.}

Reference paragraph 2-40.

a. Daily: Inspect for possible defects, leaks, damage, deterioration of lining, cracks, or settlement in foundation. 
Report promptly any such observation.

b. Quarterly.

(1) Item 2. Make a more thorough examination of the chimney exterior using high powered binoculars quarterly or after every severe storm to look for cracks, spalls, corrosion, loose guy wires (if provided), damaged lightning rod and connectors, loose parts, etc.

(2) Item 3. Remove soot and fly-ash accumulation from base of stack.

(3) Item 4. Clean accumulation of soot and fly ash from connecting flues and inspect them for corrosion, erosion, and moisture. If moisture is found, clean more frequently. Remove the cause of water formation if possible.

c. Semi-Annually: Item 5. Carefully examine stack supports for corrosion, cracking, or movement of anchor blocks, and proper guy wire tension. Check for corrosion of the ladder.

d. Annually: Item 6. Clean and inspect the stack internally and externally. Inspect lightning rod tips and ground connections. Paint.

\section{5-3I. ZEOLITE WATER SOFTENERS.}

Reference paragraph 4-6a and 4-16b.

a. Daily.

(1) Check for the following:

(a) Flow rates. Service, backwash, regenerant solution, and rinse rates should be carefully maintained.

(b) Adherence to manufacturers instructions for length of time for backwash, regeneration, and rinse operations.

(c) Proper operation of flow regulators, meters, pressure gages, temperature indicators.

(d) Chemical or water leaks.

(e) Hardness of water leaving softener to determine when to regenerate.

(f) Density of brine.

(g) Sump for zeolite carryover.

(2) Establish lubrication requirements and schedule in accordance with manufacturers recommendations.

\section{b. Semi-Annually.}

(1) Item 3. Inspect ion exchange vessel, valves, and piping for corrosion, rust, and pecling of paint.

(2) Item 4. Drain and internally inspect the ion exchange vessel for loss of resin, dirt, slime, or oil fouling of the bed, uneven bed, or corrosion or erosion in distributor piping.

c. Annually: Item 5. Calibrate instruments annually or more often as required.

\section{5-32. HOT LIME-SODA SOFTENERS.}

Reference paragraph 4-6b and 4-16b.

a. Daily.
(1) Check for the following:

(a) Alkalinity and hardness several times each day to determine proper chemical additions.

(b) Chemical feed pump for operation.

(c) Plugging of feed lines.

(d) Chemical proportioner for operation.

(e) Temperature of water in reaction tank to verify heater function. Temperature should be greater than $212^{\circ} \mathrm{F}$ at sea level.

(f) Heater vent for proper venting.

(g) Live steam makeup valve for operation and pressure control.

(h) Pressure differential across filters to determine necessity of backwashing. required.

(i) Chemical solution tank. Add chemicals as immediately.

(j) All lilnes and valves for leakage. Repair or replace

(2) Blow down rection tank daily or more often according to sludge accumulation.

(3) Lubricate motors and pumps according to manufacturers directions and schedule.

b. Monthly.

(1) Item 4. Clean chemical solution tank. Clean outlet strainer.

(2) Item 5. Clean and flush chemical feed pump.

(3) Item 6. Lubricate and adjust chemical proportioner. c. Semi-Annually.

(1) Item 7. Open and clean heater. Level and adjust trays and spray nozzles. Clean and drain vent condenser. Repack and reseat live steam regulator valve. Check diaphragm in regulator and replace if worn. Adjust regulator. Repack and reseat water inlet control valve.

(2) Item 8. Open, examine, clean, and recharge filters in accordance with manufacturers recommendations.

d. Annually.

(1) Item 9. Drain, open, and clean reaction tank. Repair or replace damaged insulation. If corrosion is excessive on interior of tank, scrape thoroughly and apply protective paint or other similar coating. If exterior is exposed, paint after thoroughly cleaning.

(2) Item 10. Dismantle, clean, overhaul, and repack pumps.

(3) Item 11. Repack valves.

(4) Item 12. Paint exposed surfaces.

\section{5-33. DEAERATING HEATERS AND DEAERATORS.}

Refernce paragraph 4-6h and 4-16c.

a. Daily.

(1) Check for correct operation of relief valve, steam pressure reducing valve, overflow, controls, alarms, and 
TM 5-650

steam pressure and temperature indicators. Report any malfunctions immediately.

(2) Inspect for steam and water leaks. Repair immediately.

b. Annually: Item 3. Once a year, or more often under severe service conditions, clean the unit and inspect the following:

(1) Spray valves for corrosion, erosion, scaling, and proper seating.

(2) Water discharge nozzles for clogging, corrosion, and wear.

(3) Trays (on tray type units). Remove and inspect for corrosion, warping, and scaling.

(4) Oil separator. Inspect interior of heater for evidence of oil, corrosion, or scaling.

(5) Condition of relief, steam prssure reducing, float, vent, and overflow valves.

(6) Condition of gage glass, controls, alarms, and instruments.

(7) Condition of piping and valves.

(8) Vent condenser. Open and check for corrosion, wear, clogging of tubes, and scaling.

(9) Condition of insulation. Check for cracks and peeling.

\section{5-34. PUMPS.}

Reference paragraph 2-37.

a. Daily. Inspect for the following hourly:

(1) Unusual noise or vibration.

(2) Electric motors for overheating.

(3) Hot bearings.

(4) Abnormal suction or discharge pressures.

(5) Hot stuffing box.

(6) Abnormal leakage through glands/seals.

b. Monthly. Item 2. Inspect all external gear and bearing housings for correct lubricant condition. Establish lubrication requirements and schedule in accordance with the manufacturers recommendations.

c. Annually. Item 3. Completely disassemble, clean, and inspect the pump. Check for the following:

(1) Excessive clearances.

(2) Hot and cold alignment.

(3) Corrosion or erosion of parts.

(4) Excessive wear of shafts, sleeves, bearings, and seals.

(5) Cracks, scrapes, wastage, or corrosion of gear teeth if provided.

\section{5-35. CENTRIFUGAL PUMPS.}

Reference paragraph 2-37b.

a. Daily: Inspect for the following hourly:

(1) Abnormal vibration and noise.
(2) Abnormal pressure and flow conditions.

(3) Excessive or inadequate packing leakage.

(4) Hot bearings.

(5) Hot stuffing box.

b. Semi-Annually.

(1) Item 2. Check alignment of pump and driver with the unit at stand-still and normal operating temperature.

(2) Item 3. Check shaft sleeves for scoring.

(3) Item 4. Replace packing if required.

(4) Item 5. Drain the oil from oil-lubricated bearings, flush, and refill with clean oil.

(5) Item 6. Check grease-lubricated bearings. Do not overgrease the bearings. When adding grease, remove drain plug or use a safety fitting to prevent overgreasing.

c. Annually: Item 7. Completely disassemble, clean, and inspect the pump. Check for the following:

(1) Wearing ring clearances according to manufacturers instructions. Diametric clearance between 0.005 and 0.025 inch is usual.

(2) Bearing wear and clearances. Overhaul if required, according to manufacturers instructions.

(3) Shaft for scoring, corrosion, or wear at seals, and alignment.

(4) Impellers for corrosion, erosion, or excessive wear.

(5) Calibrate pressure gages, thermometers, and flowmeters.

(6) Suction and discharge strainers for cleanliness.

\section{5-36. RECIPROCATING PUMPS.}

Reference paragraph 2-37c.

a. Daily.

(1) Inspect for the following hourly:

(a) Abnormal speed.

(b) Improper stroke length.

(c) Defective operation of lubricator.

(d) Ineffective operation of governor.

(e) Improper action of the air chamber.

(f) Steam and water leaks.

(2) Establish lubrication requirements and schedule in accordance with manufacturers instructions.

b. Monthly: Item 3. Inspect for the following:

(1) Scoring of piston rods.

(2) Binding of valve operating mechanism.

(3) Lost motion.

(4) Tilted glands in stuffing boxes.

(5) Defective condition of strainers.

c. Annually:

(1) Item 4. Dismantle the pump once a year or more often if required; clean and inspect the poump.

(2) Item 5. Check the following in the liquid end: (a) Condition of valves, springs, and retaining bolts. (b) Condition of cylinder liner. 
(c) Piston rings or packings.

(d) Piston rod packing.

(e) Relief valve, if used, and setting.

(f) Alignment.

(g) Strainers, if used.

(2) Item 6. Also look for corrosion, erosion, or excessive wear of parts, and for transmission of strains from piping to pump.

(3) Item 7. Check the following in the steam end:

(a) Condition of pistons and piston rings, slide valves and seals.

(b) Alignment.

(c) Clearance between piston and cylinder liner.

(d) Lubricator.

(e) Governor.

(4) Item 8. Check for plugged steam passages in steam chest, scoring of shoulders or cyliners, corrosion, erosion, and excessive wear of parts.

(5) Item 9. Calibı ate instruments.

(6) Item 10. Replace packings.

\section{5-37. STEAM INJECTORS.}

Reference paragraph 2-37e.

a. Daily.

(1) Inspect for steam and water leaks. Repair as required.

(2) Check for correct feedwater flow.

(3) Check for correct temperature and pressure readings.

(4) Check for erratic overflow.

b. Annually: Item 5. Dismantle injector. Clean and inspect for the following:

(1) Injectors for corrosion, erosion, excessive wear, and clogging passages. Pay particular attention to nozzles.

(2) Valves for corrosion, excessive wear, and leakage. Check packing.

(3) Piping for corrosion, scaling, and erosion.

(4) Insulation.

\section{5-38. STEAM TURBINES (NON-CONDENSING).}

Reference paragraph 2-41. Institute preventive maintenance schedule in accordance with manufacturers recommendations. The following program is suggested for a singel stage impulse non-condensing steam turbine typically used at Army installations to drive auxiliary equipment.

a. Daily.

(1) Inspect for the following:

(a) Proper oil levels, pressures, and temperatures.

(b) Hot bearings.

(c) Dirty or emulsified oil

(d) Unusual noise or vibration. (e) Steam, water and oil leaks. Repair as necessary. (f) Proper operation of governor under varying load.

(g) Proper operation of all ilnstruments, gages, and throttle valve.

(2) Establish lubrication requirements and schedule in accordance with manufacturers instructions.

b. Weekly.

(1) Item 3. Blow down steam strainer connection.

(2) Item 4. Lubricate governor and overspeed trip linkages.

(3) Item 5. Trip emergency valve by hand trip lever to check its operability.

c. Monthly.

(1) Item 6. Change bearing oil and clean reservoir.

(2) Item 7. Make visual inspection of governor parts, bearings, and linkage for lost motion.

(3) Item 8. Check coupling for looseness, wear, and alignment.

d. Annually: Item 9. Make a thorough inspection of the unit after the first year of operation. Subsequent internal inspection intervals should be based upon operating conditions and the operating record of the machine. Follow manufacturers recommendations for such inspections. The following may be adopted as guidelines for an annual overhaul:

(1) Dismantle speed governor and check and rectify play in linkage.

(2) Check overspeed trip governor for proper opoeration. Repair if necessary.

(3) Clean and examine governor valve, bushing, valve stem, etc. Replace stem packing.

(4) Check thrust bearing for end play.

(5) Clean and examine turbine blades and shrouds for cracks, damage, erosion, and debris.

(6) Clean steam strainer.

(7) Clean and inspect packing rings for damage and axial rubs.

(8) Inspect turbine bearings. Change if necessary.

\section{5-39. AIR COMPRESSORS.}

Reference paragraph 2-45.

a. Daily.

(1) Inspect for the following:

(a) Unusual noise or vibration.

(b) Abnormal temperature and prssure of compressed air, cooling water, or lubricating oil.

(c) Proper operation of unloader.

(d) Hot bearings and stuffing box.

(e) Correct lubricating oil level and oil consistency.

(2) Establish lubrication requirements and schedule in accordance with manufacturers recommendations.

b. Quarterly: Item 3. Inspect for the following: 
TM 5-650

(1) Compressor valves for wear, dirt, and improper seating.

(2) Operation of all safety valves.

(3) Belts for tension, wear, and deterioration.

(4) Cleanliness of air intake filter.

(5) Tightness of cylinder head bolts and gaskets.

c. Annually.

(1) Item 4. Check cylinders for wear, scoring, corrosion, and dirt.

(2) Item 5. Inspect pistons and rings for leakage, wear, scoring, security to the piston rod, and head clearances.

(3) Item 6. Inspect crank shaft and crank shaft bearings for wear and proper operation.

(4) Item 7. Check alilgnment of the compressor with respect to the driver.

\section{5-40. STEAM TRAPS.}

Reference paragraph 2-46. Establish a comprehensive and coordinated maintenance and inspection program for all steam traps, strainers, and separators. As a minimum, the following must be done for central boiler plants.

2. Daily: Inspect the traps, strainers, and separators for the followiing:

(1) Pining reaks. Repair as necessary.

(2) Correct operation.

(3) Abnormal pressure drop across strainers.

(4) Unusual accumulations of foreign matter in strainer baskets.

(5) Unusual and excessive discharge of condensate and oil from separators.

(6) Damage to insulation at traps. Repair as necessary. b. Monthly.

(1) Item 2. Blow down steam trap to eliminate dirt accumulations.

(2) Item 3. Open the air vents on float traps to vent accumulated air.

(3) Item 4 Test traps for correct operation.

c. Annually.

(1) Item 5. Completely disassemble all steam traps and inspect them carefully for the following:

(a) Cracked, corroded, broken, loose, or worn parts.

(b) Excessive wear, grooving, and wire drawing of valves and seats.

(c) Defective bellows, buckets, or floats.

(2) Item 6. Replace or repair all defective gaskets, linkages, and orifices.

(3) Item 7. Reassemble and test for proper operation.

\section{5-41. ELECTRIC MOTORS.}

Reference paragraph 2-42. Also reference TM 5-683 entitled Facilities Engineering Electrical Interior Facilities. a. Daily.
(1) Inspect for the following:

(a) Cleanliness.

(b) Overheating.

(c) Hot bearings.

(d) Correct lubrication.

(e) Proper operation of instruments and controls.

(f) Unusual noise or vibration. or brushes.

(g) Continuous or excessive sparking at commutator

(h) Loose belts, if provided.

(2) Establish lubrication and motor maintenance in accordance with manufacturers recommendatins.

b. Annually.

(1) Item 3. Inspect squirrel cage rotors for broken or loose bars. Check for loose or broken fan blades.

(2) Item 4. Thoroughly inspect all ball, roller, and sleeve bearings for wear and dirt.

(3) Item 5. Check and record insulation resistance.

(4) Item 6. Check windings for dirt, moisture, cracks, and loose wedges.

(5) Item 7. Check coupling alignment.

\section{5-42. FORCED DRAFT AND INDUCED-DRAFT FANS.}

Reference paragraphs 2-38 and 2-39.

a. Daily.

(1) Inspect for the following:

(a) Abnormal noises.

(b) Abnormal vibration.

(c) Overheating of drive.

(d) Abnormal bearing temper ature.

(e) Condition of oil and bearing oil level.

(f) Proper flow and temperature of bearing-cooling water.

(g) Freedom of damper motion.

(2) Establish lubrication requirements and schedule in accordance with manufacturers recommendations.

b. Quarterly.

(1) Item 3. Examine water cooling system for corrosion and clogging.

(2) Item 4. Clean rotor and casing and inspect for corrosion, erosion, and damage. Check clearances between rotor and casing.

(3) Item 5. Check alignment of shaft and coupling; inspect coupling.

(4) Item 6. Check condition of foundation and tightness of bearing and foundation bolts. Defective foundation or loose bolts may promote heavy vibration.

(5) Item 7. Inspect bearings.

c. Annually: Item 8. Annually, or more often if required, inspect and perform the following maintenance work:

(1) Complete by overhaul bearings. 
(2) Clean and flush cooling system.

(3) Repair or replace fan blades, as required. After replacing blades, rebalance rotor.

(4) Repair or replace defective parts.

(5) Repair insulation.

\section{5-43. COMMAND INSPECTIONS.}

Command inspections are a function of commanding officers. They are made to determine the general condition and effective use of central boiler plant equipment, causes of neglect or carelessness, and need for additional instruction or training of operating personnel. Command inspections may be formal, informal, or spot checks.

a. Procedure. Command inspections are made on accessible central boiler plant equipment at any time that causes the least possible interference with boiler plant routine. All equipment, accessories, and connections are checked during formal inspections; equipment is selected at random for informal inspections and spot checks. Inspectors look for the following:

(1) Cleanliness of equipment, pipes, walks, floors, walls, and instruments.

(2) Any leaks from water, steam, oil, or air equipment.

(3) Neat and orderly storage tools, spare parts, upplies, and fuel.

(4) Deficiencies of equipment, working order of parts.

(5) Prompt notification to the Director of Engineering and Housing of all opoerating deficiencies.

(6) Methods and procedures used in hazardous opertions.

b. Follow-Up. After inspections have been completed, personnel are advised of the deficiencies and irregularities noted.

\section{5-44. TECHNICAL INSPEZCTION.}

Technical inspections are made by the Director of Engineering and Housing or designated personnel of his organizatrion to determine the general condition of boiler plant equipment, effectiveness of preventive maintenance , and need for additional instruction or training of maintenance personnel.

a. Procedure. Boiler plant equipment is selected at random and inspected without previous notification so that the overall condition of equipment and efficiency of maintenance personnel can be determined. Technical inspections are preferably made while equipment is being dismantled for routine inspection. In thoroughness, the technical inspection should equal inspections made by insurance or other authorized inspecting agencies. The ollowing are checked at each piece of boiler plant equipment inspected.

(1) All items included in command inspections. (See paragraph 5-43.)

(2) Adequacy of preventive maintenance as it is being performed.

b. Follow -Up. On completion of the technical inspection, the Director of Engineering and Housing will take the steps necessary to correct indicated deficiencies in preventive maintenance inspection and service procedures. He will arrange to have any indicated maintenance work done at once.

\section{5-45. MAJOR ARMY COMMAND INSPECTIONS.}

Major Army Command Inspections are made by technical personnel to determine effectiveness of preventive maintenance and to ensure uniform procedures at all posts. They include examination of preventive maintenance inspection records.

a. General Inspections. Technical personnel make general inspections at least four times a year. Inspectors check the following:

(1) Preventive maintenance record system.

(2) Familiarity of maintenance personnel with equipment duties.

(3) Promptness of corrective action when Director of Engineering and Housing is notified of defects.

b. Follow-Up. Errors and oversights are reported to the proper authority. The Major Army Command maintains suitable records of inspections. These records include a list of equipment inspected, findings, recommendations, and other pertinent data. 


\section{Appendix D: Fort Wainwright Cost Details}




\begin{tabular}{|c|c|c|c|c|c|c|c|c|c|c|}
\hline & 2006 & 2006 & 2007 & 2007 & 2008 & 2008 & 2009 & 2009 & 2010 & 2010 \\
\hline Boiler repairs & Material & Labor & Material & Labor & Material & Labor & Material & Labor & Material & Labor \\
\hline $\begin{array}{l}\text { All bottom ash -- ash pit outside doors } 4 \text { per } \\
\text { boiler total } 24\end{array}$ & 4,800 & 25,200 & 4,800 & 25,200 & 4,800 & 25,200 & 4,800 & 25,200 & 4,800 & 25,200 \\
\hline $\begin{array}{l}\text { All bottom ash - ash pit inside doors and all } \\
\text { tubing } 4 \text { ea --total } 24\end{array}$ & 4,000 & 17,000 & 4,000 & 17,000 & 4,000 & 17,000 & 4,000 & 17,000 & 4,000 & 17,000 \\
\hline All ash grinders--4 per boiler--total 24 & 503,800 & 93,600 & 503,800 & 93,600 & 503,800 & 93,600 & 503,800 & 93,600 & 503,800 & 93,600 \\
\hline $\begin{array}{l}\text { All bottom slide gates per boiler-4 per boiler -- } \\
\text { - total } 24\end{array}$ & 12,000 & 25,200 & 12,000 & 25,200 & 12,000 & 25,200 & 12,000 & 25,200 & 12,000 & 25,200 \\
\hline $\begin{array}{l}\text { All bottom ash pipe sections---total in floor--- } \\
60\end{array}$ & 6,000 & 6,400 & 6,000 & 6,400 & 6,000 & 6,400 & 6,000 & 6,400 & 6,000 & 6,400 \\
\hline $\begin{array}{l}\text { All bottom ash pipe sections---total above floor } \\
37\end{array}$ & 6,000 & 6,400 & 6,000 & 6,400 & 6,000 & 6,400 & 6,000 & 6,400 & 6,000 & 6,400 \\
\hline All gate air operated valves---15 total & 17,000 & 5,400 & 17,000 & 5,400 & 17,000 & 5,400 & 17,000 & 5,400 & 17,000 & 5,400 \\
\hline $\begin{array}{l}\text { All hydraulic tubing and cooling lines for ash } \\
\text { door controls and cooling }\end{array}$ & 2,400 & 20,200 & 2,400 & 20,200 & 2,400 & 20,200 & 2,400 & 20,200 & 2,400 & 20,200 \\
\hline $\begin{array}{l}\text { Hydraulic pressure unit and pumps ( two high } \\
\text { pressure) }\end{array}$ & 8,000 & 2,200 & 8,000 & 2,200 & 8,000 & 2,200 & 8,000 & 2,200 & 8,000 & 2,200 \\
\hline Hydraulic reservoir kidney pump & 3,000 & 1,000 & 3,000 & 1,000 & 3,000 & 1,000 & 3,000 & 1,000 & 3,000 & 1,000 \\
\hline All fly ash swing gates--3each boiler---18 total & 18,000 & 19,000 & 18,000 & 19,000 & 18,000 & 19,000 & 18,000 & 19,000 & 18,000 & 19,000 \\
\hline $\begin{array}{l}\text { Boiler blow down flash tank and all connecting } \\
\text { lines }\end{array}$ & 6,000 & 17,000 & 6,000 & 17,000 & 6,000 & 17,000 & 6,000 & 17,000 & 6,000 & 17,000 \\
\hline Waste pump with motor for flash tank & 9,600 & 3,800 & 9,600 & 3,800 & 9,600 & 3,800 & 9,600 & 3,800 & 9,600 & 3,800 \\
\hline $\begin{array}{l}\text { Air cushion tank for ash door hydraulic lifts--1 } \\
\text { ea boiler-total } 6\end{array}$ & 3,000 & 2,600 & 3,000 & 2,600 & 3,000 & 2,600 & 3,000 & 2,600 & 3,000 & 2,600 \\
\hline $\begin{array}{l}\text { All swing gate riddling ash gates } 2 \text { ea boiler-- } \\
\text { total } 12\end{array}$ & 7,600 & 19,600 & 7,600 & 19,600 & 7,600 & 19,600 & 7,600 & 19,600 & 7,600 & 19,600 \\
\hline
\end{tabular}




\begin{tabular}{|c|c|c|c|c|c|c|c|c|c|c|}
\hline & 2006 & 2006 & 2007 & 2007 & 2008 & 2008 & 2009 & 2009 & 2010 & 2010 \\
\hline Boiler repairs & Material & Labor & Material & Labor & Material & Labor & Material & Labor & Material & Labor \\
\hline $\begin{array}{l}\text { All air regulating valves and solenoids for } \\
\text { riddling system } 2 \text { ea }\end{array}$ & 1,600 & 800 & 1,600 & 800 & 1,600 & 800 & 1,600 & 800 & 1,600 & 800 \\
\hline Riddling ash line sections total 64 & 18,000 & 33,800 & 18,000 & 33,800 & 18,000 & 33,800 & 18,000 & 33,800 & 18,000 & 33,800 \\
\hline All six complete stokers on all six boilers & 100,320 & 4,000 & 100,320 & 4,000 & 100,320 & 4,000 & 100,320 & 4,000 & 100,320 & 4,000 \\
\hline All six boiler coal bed, rolling grates & 24,000 & 31,600 & 24,000 & 31,600 & 24,000 & 31,600 & 24,000 & 31,600 & 24,000 & 31,600 \\
\hline $\begin{array}{l}\text { All six boiler stoker cooling water supply lines } \\
\text { and valves }\end{array}$ & 24,000 & 25,400 & 24,000 & 25,400 & 24,000 & 25,400 & 24,000 & 25,400 & 24,000 & 25,400 \\
\hline All stoker draft tubes/six per boiler/six boilers & 36,000 & 15,200 & 36,000 & 15,200 & 36,000 & 15,200 & 36,000 & 15,200 & 36,000 & 15,200 \\
\hline $\begin{array}{l}\text { All boiler and mud drum blow down valves per } \\
\text { boiler, six boilers, } 56 \text { valves total }\end{array}$ & 23,200 & 24,400 & 23,200 & 24,400 & 23,200 & 24,400 & 23,200 & 24,400 & 23,200 & 24,400 \\
\hline $\begin{array}{l}\text { All boiler and mud drum blow down seatless } \\
\text { valves, six boilers, } 56 \text { total valves }\end{array}$ & 23,200 & 24,400 & 23,200 & 24,400 & 23,200 & 24,400 & 23,200 & 24,400 & 23,200 & 24,400 \\
\hline All cinder re-injection tubes on all six boiler & 6,000 & 5,000 & 6,000 & 5,000 & 6,000 & 5,000 & 6,000 & 5,000 & 6,000 & 5,000 \\
\hline $\begin{array}{l}\text { All cinder re-injection hopper slide gates on all } \\
\text { six boilers }\end{array}$ & 3,000 & 6,400 & 3,000 & 6,400 & 3,000 & 6,400 & 3,000 & 6,400 & 3,000 & 6,400 \\
\hline $\begin{array}{l}\text { All cinder re-injection fans --- 1ea ---- six boil- } \\
\text { ers---six total }\end{array}$ & 24,000 & 12,600 & 24,000 & 12,600 & 24,000 & 12,600 & 24,000 & 12,600 & 24,000 & 12,600 \\
\hline $\begin{array}{l}1 \text { ea under grate zone louvers and control arm } \\
\text { per boiler }\end{array}$ & 30,000 & 19,000 & 30,000 & 19,000 & 30,000 & 19,000 & 30,000 & 19,000 & 30,000 & 19,000 \\
\hline $\begin{array}{l}1 \text { ea blast gate louver and control arm per } \\
\text { boiler }\end{array}$ & 30,000 & 19,000 & 30,000 & 19,000 & 30,000 & 19,000 & 30,000 & 19,000 & 30,000 & 19,000 \\
\hline 1 each forced draft motor per boiler -- total 6 & 18,000 & 12,600 & 18,000 & 12,600 & 18,000 & 12,600 & 18,000 & 12,600 & 18,000 & 12,600 \\
\hline 100 safety glass windows and panes & 6,000 & 10,600 & 6,000 & 10,600 & 6,000 & 10,600 & 6,000 & 10,600 & 6,000 & 10,600 \\
\hline De-superheater in \#4 lateral & 6,000 & 6,400 & 6,000 & 6,400 & 6,000 & 6,400 & 6,000 & 6,400 & 6,000 & 6,400 \\
\hline Overhauls/tube replacements & & & & & & & & & & \\
\hline
\end{tabular}




\begin{tabular}{|c|c|c|c|c|c|c|c|c|c|c|c|}
\hline & & 2006 & 2006 & 2007 & 2007 & 2008 & 2008 & 2009 & 2009 & 2010 & 2010 \\
\hline & Boiler repairs & Material & Labor & Material & Labor & Material & Labor & Material & Labor & Material & Labor \\
\hline & Subtotal boiler repairs & 984,520 & 515,800 & 984,520 & 515,800 & 984,520 & 515,800 & 984,520 & 515,800 & 984,520 & 515,800 \\
\hline & Turbine repairs & & & & & & & & & & \\
\hline & St 1 maintenance and repair & 175,000 & 25,000 & 85,000 & 15,000 & 100,000 & 25,000 & 103,750 & 25,000 & 105,113 & 27,500 \\
\hline & St 1 overhaul & & & & & & & & & 900,000 & 100,000 \\
\hline & St 3 maintenance and repair & 175,000 & 25,000 & 85,000 & 15,000 & 100,000 & 25,000 & 103,750 & 25,000 & 105,113 & 27,500 \\
\hline & St 3 overhaul & & & & & & & & & & \\
\hline & St 4 maintenance and repair & 175,000 & 25,000 & 85,000 & 15,000 & 100,000 & 25,000 & 103,750 & 25,000 & 105,113 & 27,500 \\
\hline & St 4 overhaul & & & & & & & 900,000 & 100,000 & & \\
\hline & St 5 maintenance and repair & 175,000 & 25,000 & 85,000 & 15,000 & 100,000 & 25,000 & 103,750 & 25,000 & 105,113 & 27,500 \\
\hline & St 5 overhaul & & & & & 900,000 & 100,000 & & & & \\
\hline & Subtotal steam turbine & 700,000 & 100,000 & 340,000 & 60,000 & $\begin{array}{l}1,300,00 \\
0\end{array}$ & 200,000 & $\begin{array}{l}1,315,00 \\
0\end{array}$ & 200,000 & $\begin{array}{l}1,320,45 \\
2\end{array}$ & 210,000 \\
\hline & Balance of plant & & & & & & & & & & \\
\hline \multicolumn{12}{|c|}{ Coal handling systems } \\
\hline COAL & Ball bearing greasing & 800 & 8,000 & 800 & 8,000 & 800 & 8,000 & 800 & 8,000 & 800 & 8,000 \\
\hline COAL & $\begin{array}{l}\text { Inspect/replace crusher hammer and suspen- } \\
\text { sion bars }\end{array}$ & 7,000 & 5,400 & 7,000 & 5,400 & 7,000 & 5,400 & 7,000 & 5,400 & 7,000 & 5,400 \\
\hline COAL & $\begin{array}{l}\text { Inspection/replacement of components that } \\
\text { suffer most from the erosion and abrasion } \\
\text { wear (track grizzly, apron, etc.) }\end{array}$ & 4,000 & 5,400 & 4,000 & 5,400 & 4,000 & 5,400 & 4,000 & 5,400 & 4,000 & 5,400 \\
\hline COAL & $\begin{array}{l}\text { Inspection/replacement of belt cleaner and } \\
\text { plows, idlers, pulley assemblies, conveyor and } \\
\text { feeding belting, storage pile discharger, } \\
\text { chutes, magnetic separator, belt scale, duct } \\
\text { collectors, exhaust fan }\end{array}$ & 5,000 & 12,800 & 5,000 & 12,800 & 5,000 & 12,800 & 5,000 & 12,800 & 5,000 & 12,800 \\
\hline
\end{tabular}




\begin{tabular}{|c|c|c|c|c|c|c|c|c|c|c|c|}
\hline & & 2006 & 2006 & 2007 & 2007 & 2008 & 2008 & 2009 & 2009 & 2010 & 2010 \\
\hline & Boiler repairs & Material & Labor & Material & Labor & Material & Labor & Material & Labor & Material & Labor \\
\hline COAL & Major inspection and repair activities & 40,000 & 85,000 & 40,000 & 85,000 & 40,000 & 85,000 & 40,000 & 85,000 & 40,000 & 85,000 \\
\hline \multicolumn{12}{|c|}{ Ash systems (including baghouse/id fan/env cont) } \\
\hline ASH & $\begin{array}{l}\text { Replace all bottom ash pipe sections in verti- } \\
\text { cal lines } 7 \text { stories }\end{array}$ & 8,000 & 20,160 & 8,000 & 20,160 & 8,000 & 20,160 & 8,000 & 20,160 & 8,000 & 20,160 \\
\hline ASH & $\begin{array}{l}\text { Replace ash control system panel and con- } \\
\text { trols }\end{array}$ & 10,000 & 8,400 & 10,000 & 8,400 & 10,000 & 8,400 & 10,000 & 8,400 & 10,000 & 8,400 \\
\hline ASH & Replace fly ash line sections & 2,400 & 5,100 & 2,400 & 5,100 & 2,400 & 5,100 & 2,400 & 5,100 & 2,400 & 5,100 \\
\hline ASH & Ball bearing greasing & 800 & 8,800 & 800 & 8,800 & 800 & 8,800 & 800 & 8,800 & 800 & 8,800 \\
\hline ASH & $\begin{array}{l}\text { Inspection for vacuum leaking and ero- } \\
\text { sion/elbows replacement }\end{array}$ & 3,000 & 4,200 & 3,000 & 4,200 & 3,000 & 4,200 & 3,000 & 4,200 & 3,000 & 4,200 \\
\hline ASH & Screw conveyor liner inspection/replacement & 1,500 & 1,600 & 1,500 & 1,600 & 1,500 & 1,600 & 1,500 & 1,600 & 1,500 & 1,600 \\
\hline ASH & Valve liner inspection/replacement & 1,000 & 4,200 & 1,000 & 4,200 & 1,000 & 4,200 & 1,000 & 4,200 & 1,000 & 4,200 \\
\hline ASH & $\begin{array}{l}\text { Replacement of filter bags and other compo- } \\
\text { nents that suffer most from dust exposure } \\
\text { (assume } 100 \text { bags) }\end{array}$ & 1,400 & 5,200 & 1,400 & 5,200 & 1,400 & 5,200 & 1,400 & 5,200 & 1,400 & 5,200 \\
\hline ASH & Major inspection and repair activities & 40,000 & 35,000 & 40,000 & 35,000 & 40,000 & 35,000 & 40,000 & 35,000 & 40,000 & 35,000 \\
\hline \multicolumn{12}{|c|}{ Steam piping } \\
\hline STEAM & $\begin{array}{l}\text { Replace (1) } 100 \mathrm{lb} \text { pressure regulating valve } \\
\text { (steam) }\end{array}$ & 3,000 & 2,200 & 3,000 & 2,200 & 3,000 & 2,200 & 3,000 & 2,200 & 3,000 & 2,200 \\
\hline STEAM & $\begin{array}{l}\text { Replace (1) } 50 \mathrm{lb} \text { pressure regulating valve } \\
\text { (steam) }\end{array}$ & 1,800 & 600 & 1,800 & 600 & 1,800 & 600 & 1,800 & 600 & 1,800 & 600 \\
\hline STEAM & $\begin{array}{l}\text { Replace (1) two story } 400 \mathrm{lb} \text { auxiliary steam } \\
\text { line and all connecting piping }\end{array}$ & 29,000 & 13,600 & 29,000 & 13,600 & 29,000 & 13,600 & 29,000 & 13,600 & 29,000 & 13,600 \\
\hline STEAM & Replace 50 lb steam prv \#14 & 1,800 & 600 & 1,800 & 600 & 1,800 & 600 & 1,800 & 600 & 1,800 & 600 \\
\hline STEAM & Replace $10 \mathrm{lb}$ steam prv & 1,400 & 400 & 1,400 & 400 & 1,400 & 400 & 1,400 & 400 & 1,400 & 400 \\
\hline
\end{tabular}




\begin{tabular}{|c|c|c|c|c|c|c|c|c|c|c|c|}
\hline & & 2006 & 2006 & 2007 & 2007 & 2008 & 2008 & 2009 & 2009 & 2010 & 2010 \\
\hline & Boiler repairs & Material & Labor & Material & Labor & Material & Labor & Material & Labor & Material & Labor \\
\hline STEAM & Replace 200 lb steam prv & 2,000 & 600 & 2,000 & 600 & 2,000 & 600 & 2,000 & 600 & 2,000 & 600 \\
\hline STEAM & $\begin{array}{l}\text { Inspect/replace } 100 \text { psig system } 18 \text { " bellow } \\
\text { expansion joints }\end{array}$ & 600 & 800 & 600 & 800 & 600 & 800 & 600 & 800 & 600 & 800 \\
\hline STEAM & $\begin{array}{l}\text { Prv, control, shutoff and check valves inspec- } \\
\text { tion/maintenance }\end{array}$ & 1,000 & 2,200 & 1,000 & 2,200 & 1,000 & 2,200 & 1,000 & 2,200 & 1,000 & 2,200 \\
\hline STEAM & Replacement of steam piping & 25,000 & 5,000 & 25,000 & 5,000 & 25,000 & 5,000 & 25,000 & 5,000 & 25,000 & 5,000 \\
\hline$\star * * * * *$ & $\begin{array}{l}\text { Nde inspection of tees, elbows, piping, and } \\
\text { valve discharge areas }\end{array}$ & 12,500 & 2,500 & 12,500 & 2,500 & 12,500 & 2,500 & 12,500 & 2,500 & 12,500 & 2,500 \\
\hline \multicolumn{12}{|c|}{ Feedwater / condensate sys } \\
\hline $\mathrm{FW}$ & Fw pumps inspection and maintenance & 3,077 & 9,692 & 3,077 & 9,692 & 3,077 & 9,692 & 3,077 & 9,692 & 3,077 & 9,692 \\
\hline $\mathrm{FW}$ & Fw piping replacement & 15,000 & 2,000 & 15,000 & 2,000 & 15,000 & 2,000 & 15,000 & 2,000 & 15,000 & 2,000 \\
\hline $\mathrm{FW}$ & Fw piping nde & 2,000 & - & 2,000 & - & 2,000 & - & 2,000 & - & 2,000 & - \\
\hline $\mathrm{FW}$ & Deaerator inspection and maintenance & 914 & 2,400 & 914 & 2,400 & 914 & 2,400 & 914 & 2,400 & 914 & 2,400 \\
\hline CONDEN & $\begin{array}{l}\text { Sodium cation polisher resin treatment (one } \\
\text { unit at a time) }\end{array}$ & 1,200 & 3,800 & 1,200 & 3,800 & 1,200 & 3,800 & 1,200 & 3,800 & 1,200 & 3,800 \\
\hline CONDEN & $\begin{array}{l}\text { Sodium cation polisher resin replacement } \\
\text { (one unit at a time) }\end{array}$ & 1,200 & 3,800 & 1,200 & 3,800 & 1,200 & 3,800 & 1,200 & 3,800 & 1,200 & 3,800 \\
\hline CONDEN & $\begin{array}{l}\text { Nde piping inspection in tees, elbows, valve } \\
\text { discharges areas }\end{array}$ & 1,250 & - & 1,250 & - & 1,250 & - & 1,250 & - & 1,250 & - \\
\hline CONDEN & Conden piping replacement & 10,000 & 1,500 & 10,000 & 1,500 & 10,000 & 1,500 & 10,000 & 1,500 & 10,000 & 1,500 \\
\hline CONDEN & Pump inspection/maintenance & 800 & 4,200 & 800 & 4,200 & 800 & 4,200 & 800 & 4,200 & 800 & 4,200 \\
\hline \multicolumn{2}{|l|}{ Cooling sys } & - & - & - & - & - & - & - & - & - & - \\
\hline Aux COOL & $\begin{array}{l}\text { Replace auxiliary cooling water system skids } \\
\text { motors and pumps }\end{array}$ & 8,000 & 4,200 & 8,000 & 4,200 & 8,000 & 4,200 & 8,000 & 4,200 & 8,000 & 4,200 \\
\hline
\end{tabular}




\begin{tabular}{|c|c|c|c|c|c|c|c|c|c|c|c|}
\hline & & 2006 & 2006 & 2007 & 2007 & 2008 & 2008 & 2009 & 2009 & 2010 & 2010 \\
\hline & Boiler repairs & Material & Labor & Material & Labor & Material & Labor & Material & Labor & Material & Labor \\
\hline Aux COOL & $\begin{array}{l}\text { Replace auxiliary cooling water system glycol } \\
\text { tank and lines }\end{array}$ & 2,000 & 2,200 & 2,000 & 2,200 & 2,000 & 2,200 & 2,000 & 2,200 & 2,000 & 2,200 \\
\hline & & - & - & - & - & - & - & - & - & - & - \\
\hline HVAC & $\begin{array}{l}\text { Replace two air compressor fresh air fans and } \\
\text { all duct work and motors }\end{array}$ & 6,000 & 4,200 & 6,000 & 4,200 & 6,000 & 4,200 & 6,000 & 4,200 & 6,000 & 4,200 \\
\hline HVAC & $\begin{array}{l}\text { Replace fresh air fans in east wall of turbine } \\
\text { floor and duct work added }\end{array}$ & 8,000 & 4,200 & 8,000 & 4,200 & 8,000 & 4,200 & 8,000 & 4,200 & 8,000 & 4,200 \\
\hline HVAC & $\begin{array}{l}\text { Replace turbine floor offices and control room } \\
\text { air circulation and conditioning systems (ele- } \\
\text { ments) }\end{array}$ & 63,000 & - & 63,000 & - & 63,000 & - & 63,000 & - & 63,000 & - \\
\hline S AIR & $\begin{array}{l}\text { Replace air compressors for plant operations } \\
\text { and service air }\end{array}$ & 30,000 & 3,200 & 30,000 & 3,200 & 30,000 & 3,200 & 30,000 & 3,200 & 30,000 & 3,200 \\
\hline S AIR & Replace air dryers---total 2 & 4,267 & 267 & 4,267 & 267 & 4,267 & 267 & 4,267 & 267 & 4,267 & 267 \\
\hline S AIR & Replace two stand by compressors & 14,000 & 2,200 & 14,000 & 2,200 & 14,000 & 2,200 & 14,000 & 2,200 & 14,000 & 2,200 \\
\hline S AIR & $\begin{array}{l}\text { Replace air cushion and moisture tanks } 4 \\
\text { total }\end{array}$ & 800 & 800 & 800 & 800 & 800 & 800 & 800 & 800 & 800 & 800 \\
\hline ACC & Fan & 1,200 & 6,400 & 1,200 & 6,400 & 1,200 & 6,400 & 1,200 & 6,400 & 1,200 & 6,400 \\
\hline ACC & Motors & 400 & 3,000 & 400 & 3,000 & 400 & 3,000 & 400 & 3,000 & 400 & 3,000 \\
\hline ACC & Gearbox & 400 & 3,000 & 400 & 3,000 & 400 & 3,000 & 400 & 3,000 & 400 & 3,000 \\
\hline ACC & Vibration switches & 600 & 600 & 600 & 600 & 600 & 600 & 600 & 600 & 600 & 600 \\
\hline ACC & Ejectors & 400 & 3,000 & 400 & 3,000 & 400 & 3,000 & 400 & 3,000 & 400 & 3,000 \\
\hline ACC & Isolation valves & 200 & 600 & 200 & 600 & 200 & 600 & 200 & 600 & 200 & 600 \\
\hline ACC & Pumps & 600 & 1,800 & 600 & 1,800 & 600 & 1,800 & 600 & 1,800 & 600 & 1,800 \\
\hline ACC & Fin tube bundle & 1,200 & 6,400 & 1,200 & 6,400 & 1,200 & 6,400 & 1,200 & 6,400 & 1,200 & 6,400 \\
\hline ACC & Major inspection and repair activities & - & - & - & - & - & - & - & - & - & - \\
\hline
\end{tabular}




\begin{tabular}{|c|c|c|c|c|c|c|c|c|c|c|c|}
\hline & & 2006 & 2006 & 2007 & 2007 & 2008 & 2008 & 2009 & 2009 & 2010 & 2010 \\
\hline & Boiler repairs & Material & Labor & Material & Labor & Material & Labor & Material & Labor & Material & Labor \\
\hline \multicolumn{12}{|c|}{ Water treatment } \\
\hline W TREAT & $\begin{array}{l}\text { Replace water treatment chemical tanks and } \\
\text { systems-total } 3\end{array}$ & 15,000 & 6,400 & 15,000 & 6,400 & 15,000 & 6,400 & 15,000 & 6,400 & 15,000 & 6,400 \\
\hline W TREAT & $\begin{array}{l}\text { Replace pumps for water treatment chemicals } \\
2 \text { ea-total } 6\end{array}$ & 3,000 & 2,600 & 3,000 & 2,600 & 3,000 & 2,600 & 3,000 & 2,600 & 3,000 & 2,600 \\
\hline W TREAT & Ro membrane cip procedure & 120 & 440 & 120 & 440 & 120 & 440 & 120 & 440 & 120 & 440 \\
\hline W TREAT & Plate and frame heat exchanger cleaning & 200 & 840 & 200 & 840 & 200 & 840 & 200 & 840 & 200 & 840 \\
\hline W TREAT & $\begin{array}{l}\text { Pre-filtration skid media replacement (sand- } \\
\text { anthracite) }\end{array}$ & 1,000 & 2,200 & 1,000 & 2,200 & 1,000 & 2,200 & 1,000 & 2,200 & 1,000 & 2,200 \\
\hline W TREAT & Ro skid membrane replacement & 2,000 & 4,200 & 2,000 & 4,200 & 2,000 & 4,200 & 2,000 & 4,200 & 2,000 & 4,200 \\
\hline W TREAT & Pump inspection/maintenance & - & - & - & - & - & - & - & - & - & - \\
\hline W TREAT & Major inspection and repair activities & 16,000 & & 16,000 & & 16,000 & & 16,000 & & 16,000 & \\
\hline WASTE & $\begin{array}{l}\text { Replace waste water sump pumps -- } 2 \text { with } \\
\text { motors }\end{array}$ & 3,333 & 1,833 & 3,333 & 1,833 & 3,333 & 1,833 & 3,333 & 1,833 & 3,333 & 1,833 \\
\hline WASTE & $\begin{array}{l}\text { Replace waste tank sump pumps and all lines } \\
\text { connecting }\end{array}$ & 6,000 & 4,200 & 6,000 & 4,200 & 6,000 & 4,200 & 6,000 & 4,200 & 6,000 & 4,200 \\
\hline WASTE & $\begin{array}{l}\text { Replace waste tank -- } 1000 \text { gallon holding } \\
\text { tank }\end{array}$ & 1,000 & 400 & 1,000 & 400 & 1,000 & 400 & 1,000 & 400 & 1,000 & 400 \\
\hline WASTE & Replace sewage lift station complete--2-- & 8,000 & 4,200 & 8,000 & 4,200 & 8,000 & 4,200 & 8,000 & 4,200 & 8,000 & 4,200 \\
\hline WASTE & $\begin{array}{l}\text { Replace waste oil / hazmat satellite system } \\
\text { auxiliaries drums, pumps }\end{array}$ & 2,000 & 4,200 & 2,000 & 4,200 & 2,000 & 4,200 & 2,000 & 4,200 & 2,000 & 4,200 \\
\hline WASTE & Replace waste pit sump pump & 2,000 & 1,000 & 2,000 & 1,000 & 2,000 & 1,000 & 2,000 & 1,000 & 2,000 & 1,000 \\
\hline P WATER & $\begin{array}{l}\text { Replace domestic water filter resin --- total } \\
\text { three filters--- }\end{array}$ & 300 & 600 & 300 & 600 & 300 & 600 & 300 & 600 & 300 & 600 \\
\hline P WATER & $\begin{array}{l}\text { Replace domestic water filter control valves } \\
\text { w/control panel }\end{array}$ & 3,000 & 2,200 & 3,000 & 2,200 & 3,000 & 2,200 & 3,000 & 2,200 & 3,000 & 2,200 \\
\hline
\end{tabular}




\begin{tabular}{|c|c|c|c|c|c|c|c|c|c|c|c|}
\hline & & 2006 & 2006 & 2007 & 2007 & 2008 & 2008 & 2009 & 2009 & 2010 & 2010 \\
\hline & Boiler repairs & Material & Labor & Material & Labor & Material & Labor & Material & Labor & Material & Labor \\
\hline \multicolumn{12}{|c|}{ Instrument/control } \\
\hline I\&C & $\begin{array}{l}\text { Replace all engineer stations for plant control } \\
\text { room (control room, shift foreman office, fire } \\
\text { floor) }\end{array}$ & 3,000 & 1,584 & 3,000 & 1,584 & 3,000 & 1,584 & 3,000 & 1,584 & 3,000 & 1,584 \\
\hline I\&C & $\begin{array}{l}\text { Replace all control panels in control room for } \\
\text { all plant auxiliaries. }\end{array}$ & 50,000 & 13,200 & 50,000 & 13,200 & 50,000 & 13,200 & 50,000 & 13,200 & 50,000 & 13,200 \\
\hline I\&C & Replace all plant control room pc's & 1,500 & 1,584 & 1,500 & 1,584 & 1,500 & 1,584 & 1,500 & 1,584 & 1,500 & 1,584 \\
\hline I\&C & $\begin{array}{l}\text { Repair and/or replace transmitters, switches, } \\
\text { sensors, etc. }\end{array}$ & 13,500 & 1,150 & 13,905 & 1,185 & 14,322 & 1,220 & 14,752 & 1,257 & 15,194 & 1,294 \\
\hline I\&C & Repair and/or replace dcs components & 12,000 & 1,350 & 12,360 & 1,391 & 12,731 & 1,432 & 13,113 & 1,475 & 13,506 & 1,519 \\
\hline \multicolumn{12}{|c|}{ Electrical distribution } \\
\hline EL & Demolish mcc $21-2400$ v panels & - & 3,960 & - & 3,960 & - & 3,960 & - & 3,960 & - & 3,960 \\
\hline EL & Replace $\mathrm{p} 1$ and $\mathrm{p} 2$ breaker panels & 10,000 & 3,168 & 10,000 & 3,168 & 10,000 & 3,168 & 10,000 & 3,168 & 10,000 & 3,168 \\
\hline EL & Replace p4, p5, p6, p8 breaker panels & 20,000 & 6,336 & 20,000 & 6,336 & 20,000 & 6,336 & 20,000 & 6,336 & 20,000 & 6,336 \\
\hline EL & $\begin{array}{l}\text { Replace } 2400 \text { volt panel and breakers with } \\
4160 \text { volt panel }\end{array}$ & - & - & - & - & - & - & - & - & - & - \\
\hline EL & $\begin{array}{l}\text { Demolish } 4160 \text { and } 2400 \text { volt cable tie (yel- } \\
\text { low) }\end{array}$ & - & 3,960 & - & 3,960 & - & 3,960 & - & 3,960 & - & 3,960 \\
\hline EL & $\begin{array}{l}\text { Replace all light fixtures on ceiling of turbine } \\
\text { room }\end{array}$ & 2,500 & 7,920 & 2,500 & 7,920 & 2,500 & 7,920 & 2,500 & 7,920 & 2,500 & 7,920 \\
\hline EL & $\begin{array}{l}\text { Replace all light fixtures on all electrical pan- } \\
\text { els in turbine room }\end{array}$ & 750 & 3,168 & 750 & 3,168 & 750 & 3,168 & 750 & 3,168 & 750 & 3,168 \\
\hline EL & $\begin{array}{l}\text { Replace all light fixtures on all turbine panels } \\
\text { in turbine room }\end{array}$ & - & - & - & - & - & - & - & - & - & - \\
\hline
\end{tabular}




\begin{tabular}{|c|c|c|c|c|c|c|c|c|c|c|c|}
\hline & & 2006 & 2006 & 2007 & 2007 & 2008 & 2008 & 2009 & 2009 & 2010 & 2010 \\
\hline & Boiler repairs & Material & Labor & Material & Labor & Material & Labor & Material & Labor & Material & Labor \\
\hline EL & $\begin{array}{l}\text { Replace battery cells as needed in battery } \\
\text { banks (north and south vaults) and } 1 \text { battery } \\
\text { bank replacement }\end{array}$ & 750 & 250 & 750 & 250 & 750 & 250 & 750 & 250 & 750 & 250 \\
\hline EL & $\begin{array}{l}\text { Replace breakers for dc power and also recti- } \\
\text { fier }\end{array}$ & 6,000 & 1,584 & 6,000 & 1,584 & 6,000 & 1,584 & 6,000 & 1,584 & 6,000 & 1,584 \\
\hline EL & Repair and/or replace electrical components & 40,000 & 5,000 & 41,200 & 5,150 & 42,436 & 5,305 & 43,709 & 5,464 & 45,020 & 5,628 \\
\hline $\begin{array}{l}\text { MAINT } \\
\text { SHP }\end{array}$ & $\begin{array}{l}\text { Maintenance shop equipment, small tools, } \\
\text { etc. }\end{array}$ & 15,000 & & 15,450 & & 15,914 & & 16,391 & & 16,883 & \\
\hline CONSUM & Maintenance consumables & 40,000 & & 41,200 & & 42,436 & & 43,709 & & 45,020 & \\
\hline \multirow[t]{8}{*}{ BOP } & Subtotal balance of plant & 657,461 & 400,746 & 661,076 & 400,971 & 664,800 & 401,203 & 668,635 & 401,442 & 672,585 & 401,688 \\
\hline & New technology & & & & & & & & & & \\
\hline & $\begin{array}{l}\text { Computerized maintenance management } \\
\text { system }\end{array}$ & 32,000 & 68,000 & 20,000 & & 20,000 & & 20,000 & & 20,000 & \\
\hline & Vibration analysis systems & 24,000 & & 2,000 & & 2,000 & & 2,000 & & 2,000 & \\
\hline & Thermal imaging & 19,500 & & 2,000 & & 2,000 & & 2,000 & & 2,000 & \\
\hline & Ultrasonic & 12,000 & & 2,000 & & 2,000 & & 2,000 & & 2,000 & \\
\hline & Oil analysis & 11,410 & & 11,410 & & 11,410 & & 11,410 & & 11,410 & \\
\hline & Subtotal new technology & 98,910 & 68,000 & 37,410 & - & 37,410 & - & 37,410 & - & 37,410 & - \\
\hline \multirow[t]{5}{*}{ CHPP } & Subtotal chpp bare erected costs & $\begin{array}{l}2,440,89 \\
1\end{array}$ & $\begin{array}{l}1,084,54 \\
6\end{array}$ & $\begin{array}{l}2,023,00 \\
6\end{array}$ & 976,771 & $\begin{array}{l}2,986,73 \\
0\end{array}$ & $\begin{array}{l}1,117,00 \\
3\end{array}$ & $\begin{array}{l}3,005,56 \\
5\end{array}$ & $\begin{array}{l}1,117,24 \\
2\end{array}$ & $\begin{array}{l}3,014,96 \\
7\end{array}$ & $\begin{array}{l}1,127,48 \\
8\end{array}$ \\
\hline & Owner's costs & & & & & & & & & & \\
\hline & Engineering @ 5\% & 122,045 & 54,227 & 101,150 & 48,839 & 149,336 & 55,850 & 150,278 & 55,862 & 150,748 & 56,374 \\
\hline & Project management & - & & - & & - & & - & & - & \\
\hline & Subtotal bare erected costs and owner's costs & $\begin{array}{l}2,562,93 \\
6\end{array}$ & $\begin{array}{l}1,138,77 \\
4\end{array}$ & $\begin{array}{l}2,124,15 \\
7\end{array}$ & $\begin{array}{l}1,025,61 \\
0\end{array}$ & $\begin{array}{l}3,136,06 \\
6\end{array}$ & $\begin{array}{l}1,172,85 \\
3\end{array}$ & $\begin{array}{l}3,155,84 \\
3\end{array}$ & $\begin{array}{l}1,173,10 \\
4\end{array}$ & $\begin{array}{l}3,165,71 \\
5\end{array}$ & $\begin{array}{l}1,183,86 \\
2\end{array}$ \\
\hline
\end{tabular}




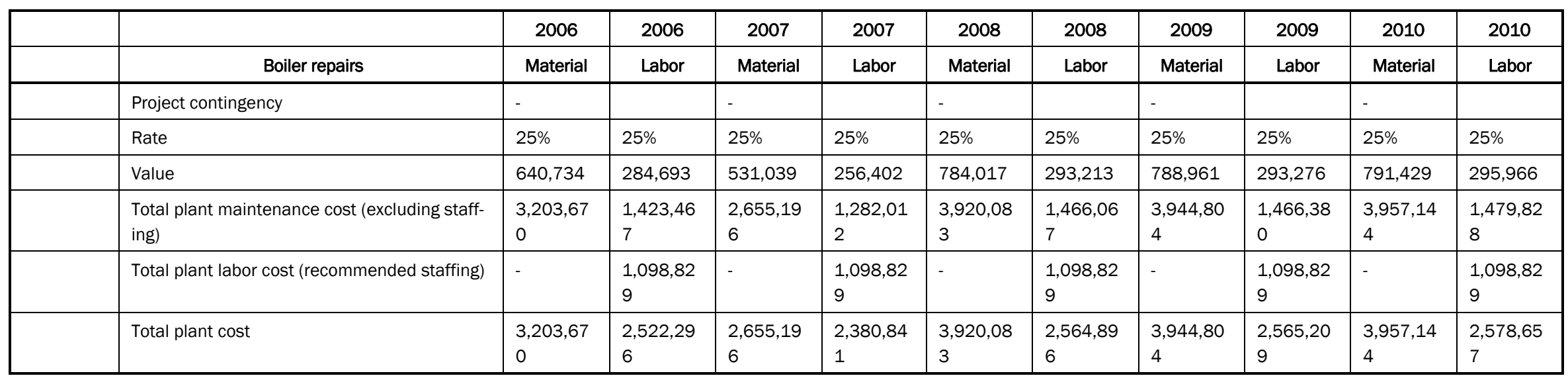




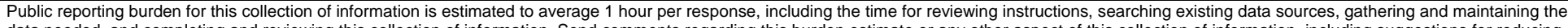

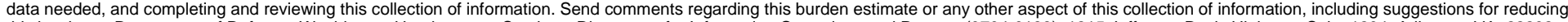

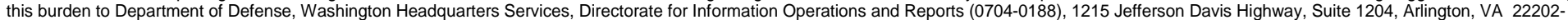

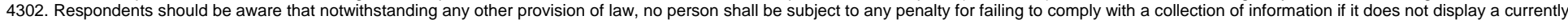
valid OMB control number. PLEASE DO NOT RETURN YOUR FORM TO THE ABOVE ADDRESS.
1. REPORT DATE (DD-MM-YYYY)
2. REPORT TYPE
3. DATES COVERED (From - To)

12-09-2007

Final

\section{TITLE AND SUBTITLE}

Preventative Maintenance and Reliability Study for the Central Heating and Power Plant at Fort

Wainwright, Alaska

5a. CONTRACT NUMBER

5b. GRANT NUMBER

5c. PROGRAM ELEMENT

6. AUTHOR(S)

John L. Vavrin, William T. Brown, Michael R. Kemme, John Westerman, Robert Lorand, Charles Walden, and Curtis Swinehart

\section{5d. PROJECT NUMBER}

MIPR

5e. TASK NUMBER

5f. WORK UNIT NUMBER

6CCERB1011R

8. PERFORMING ORGANIZATION REPORT NUMBER

ERDC/CERL TR-07-35

U.S. Army Engineer Research and Development Center (ERDC)

Construction Engineering Research Laboratory (CERL)

PO Box 9005,

Champaign, IL 61826-9005

\section{SPONSORING I MONITORING AGENCY NAME(S) AND ADDRESS(ES)}

Headquarters, Instalaltion Management Command

2511 Jefferson Davis Highway

Taylor Bldg, Rm 11E08

Arlington, VA 22202-3926

10. SPONSOR/MONITOR'S ACRONYM(S)

SFIM-OP-P

11. SPONSOR/MONITOR'S REPORT NUMBER(S)

\section{DISTRIBUTION I AVAILABILITY STATEMENT}

Approved for public release; distribution is unlimited.

\section{SUPPLEMENTARY NOTES}

\section{ABSTRACT}

The Technology Requirements Study for a new Central Heating and Power Plant (CHPP) at Fort Wainwright, Alaska (FWA) (Vavrin et al. 2006) recommended that if the option for a new CHPP were to be pursued, among the tasks suggested for further analysis was to determine predictive maintenance requirements and new technologies for the existing plant. This study was undertaken to develop a Preventative Maintenance (PM) assessment that includes a maintenance program overview for the major systems in the existing CHPP. The assessment entailed: (1) an identification of shortcomings and deficiencies of existing procedures and processes, (2) recommendations to overcome shortcomings and deficiencies, (3) development of a maintenance schedule, (4) development of an estimate of staffing requirements, and (5) development of a budget estimate for execution of the recommended PM program with breakout for costs, detailed annually for a period of 25 years. This study also identified, prioritized, and separately broke out new technologies and associated costs that would significantly improve the reliability of the existing CHPP.

15. SUBJECT TERMS

Ft.Wainwright, AK preventive maintenance central heating plants (CHP's) energy conservation maintenance power plants

\begin{tabular}{|c|c|c|c|c|c|}
\hline \multicolumn{3}{|c|}{ 16. SECURITY CLASSIFICATION OF: } & \multirow{2}{*}{$\begin{array}{l}\text { 17. LIMITATION } \\
\text { OF ABSTRACT } \\
\text { SAR }\end{array}$} & \multirow{2}{*}{$\begin{array}{l}\text { 18. NUMBER } \\
\text { OF PAGES } \\
128\end{array}$} & \multirow{2}{*}{$\begin{array}{l}\text { 19a. NAME OF RESPONSIBLE PERSON } \\
\begin{array}{l}\text { 19b. TELEPHONE NUMBER } \\
\text { (include area code) }\end{array}\end{array}$} \\
\hline $\begin{array}{l}\text { a. REPORT } \\
\text { Unclassified }\end{array}$ & $\begin{array}{l}\text { b. ABSTRACT } \\
\text { Unclassified }\end{array}$ & $\begin{array}{l}\text { c. THIS PAGE } \\
\text { Unclassified }\end{array}$ & & & \\
\hline
\end{tabular}

